\title{
Mediterranean diet and the metabolic syndrome
}

Marieke Bos 


\section{Promotoren:}

Prof. dr. ir. C.P.G.M. de Groot

Hoogleraar Voedingsfysiologie met bijzondere aandacht voor het Verouderingsproces

en de Oudere Mens, Afdeling Humane Voeding, Wageningen Universiteit

Prof. dr. ir. E.J.M. Feskens

Persoonlijk hoogleraar

Afdeling Humane Voeding, Wageningen Universiteit

\section{Copromotor:}

Dr. J.H.M. de Vries

Universitair docent

Afdeling Humane Voeding, Wageningen Universiteit

\section{Promotiecommissie:}

Prof. dr. R.F. Witkamp

Wageningen Universiteit

Prof. dr. R.P. Mensink

Universiteit Maastricht

Prof. dr. R.P. Stolk

Universitair Medisch Centrum Groningen

Rijksuniversiteit Groningen

Prof. dr. L. Serra-Majem

University of Las Palmas, Gran Canaria, Spain

Dit onderzoek is uitgevoerd binnen de onderzoeksschool VLAG. 


\section{Mediterranean diet and the metabolic syndrome}

Marieke Béanne Bos

\section{ProefsChRIFT}

Ter verkrijging van de graad van doctor op gezag van de rector magnificus van Wageningen Universiteit,

Prof. dr. M.J. Kropff, in het openbaar te verdedigen op woensdag 27 mei 2009 des namiddags te vier uur in de Aula. 
Marieke Bos

Mediterranean diet and the metabolic syndrome

Thesis Wageningen University, Wageningen, the Netherlands, 2009.

With summaries in English and Dutch.

ISBN 978-90-8585-375-6 


\section{Abstract}

\section{Mediterranean diet and the metabolic syndrome}

Background: The metabolic syndrome refers to a clustering of risk factors including abdominal obesity, hyperglycaemia, low HDL-cholesterol, hypertriglyceridaemia, and hypertension and it is a risk factor for diabetes mellitus type 2 and cardiovascular disease. In this thesis we studied whether a Mediterranean diet favourably affects the metabolic syndrome.

Methods: We assessed the association between a Mediterranean diet and the metabolic syndrome in apparently healthy elderly European subjects (SENECA study) and in a Dutch study population that was oversampled with subjects with impaired glucose tolerance or diabetes mellitus type 2 (CoDAM study). In addition, we conducted a controlled-feeding trial to compare the effects of replacing a high saturated fatty acids (SFA) diet with a high monounsaturated fatty acids (MUFA) diet or a Mediterranean diet on characteristics of the metabolic syndrome: HDL-cholesterol, triglycerides and glucose metabolism (glucose concentration and insulin sensitivity).

Results: In both the SENECA study and the feeding trial we find support for the hypothesis that a Mediterranean diet has a beneficial effect on two characteristics of the metabolic syndrome, namely HDL-cholesterol and triglyceride concentrations. In addition, the findings of the SENECA study suggested that subjects with good adherence to a Mediterranean diet had a lower prevalence of the metabolic syndrome (prevalence ratio $0.81,95 \% \mathrm{CI} 0.65 ; 1.03)$ and a smaller waist circumference $(-1.1 \mathrm{~cm}$, $95 \% \mathrm{CI}-2.4 ; 0.3)$ than subjects with poor adherence. In the CoDAM study, we did not find these associations. In none of our studies we found support for the hypothesis that a Mediterranean diet has a beneficial effect on glucose concentration, insulin sensitivity or blood pressure.

Conclusion: This thesis finds support for a beneficial effect on two out of five characteristics of the metabolic syndrome and also suggests a beneficial effect on a third characteristic (abdominal obesity). We therefore conclude that a Mediterranean diet may help to prevent the metabolic syndrome and consequently diabetes mellitus type 2 and cardiovascular disease. 


\section{Contents}

Chapter 1

Introduction

Chapter 2

The prevalence of the metabolic syndrome in the Netherlands: increased

7

risk of cardiovascular diseases and diabetes mellitus type 2 in one

quarter of persons under 60 years of age

\section{Chapter 3}

Association between a Mediterranean diet and the metabolic syndrome in elderly European subjects: the SENECA study

\section{Chapter 4}

Association between a Mediterranean diet and markers of glucose

metabolism in Dutch adults: the CoDAM study

\section{Chapter 5}

Effect of a high monounsaturated fatty acids diet and a Mediterranean

diet on serum lipids and insulin sensitivity in adults with mild abdominal obesity

\section{Chapter 6}

Effect of a high monounsaturated fatty acids diet and a Mediterranean

diet on apolipoprotein A-I and apolipoprotein B in adults with mild abdominal obesity

\section{Chapter 7}

Discussion

$\begin{array}{ll}\text { References } & 67\end{array}$

$\begin{array}{ll}\text { Summary } & 77\end{array}$

$\begin{array}{ll}\text { Samenvatting } & \mathbf{8 1}\end{array}$

$\begin{array}{ll}\text { Dankwoord } & 85\end{array}$

$\begin{array}{ll}\text { About the author } & 91\end{array}$ 


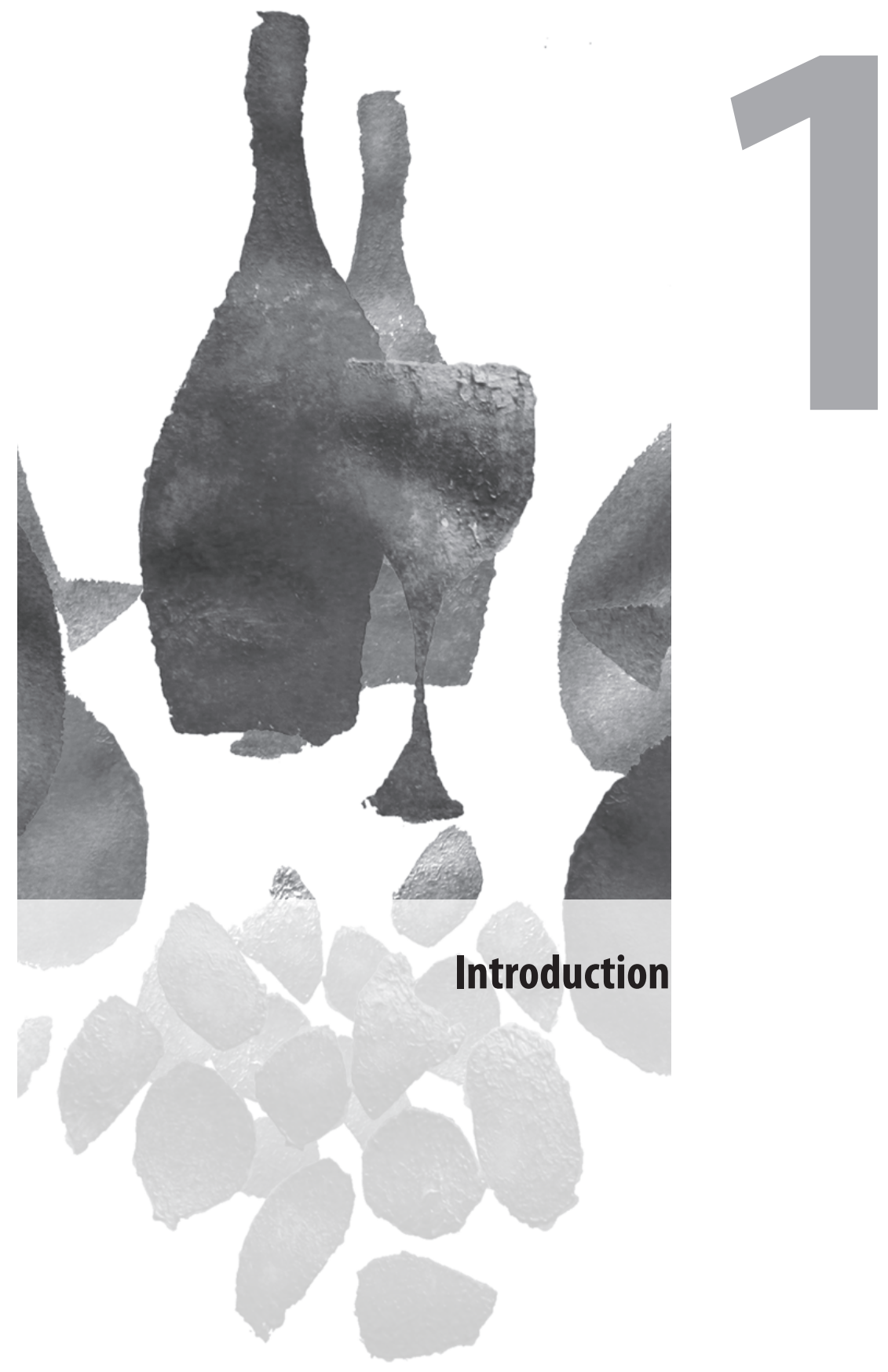




\section{The metabolic syndrome}

The number of people with diabetes mellitus or cardiovascular disease is high due to the ageing of population and the obesity epidemic. Diabetes mellitus type 2 and cardiovascular disease have a number of risk factors in common: low HDL-cholesterol concentrations, hypertriglyceridaemia, obesity, hyperglycaemia and hypertension. These risk factors tend to cluster in the same individual. Gerald Reaven was the first to suggest that these risk factors are related to each other. He called this clustering of risk factors "syndrome X" and proposed that insulin resistance was the underlying mechanism of this syndrome [1]. After Reaven had launched the idea of the syndrome, the name of the clustering of risk factors has changed from syndrome $\mathrm{X}$ to become known as the metabolic syndrome. According to a meta-analysis of 37 studies, it has been shown to be associated with an increased risk of cardiovascular events and death (RR $1.78,95 \%$ CI 1.58; 2.00) [2]. In addition, the metabolic syndrome has been shown to be associated with an increased risk of diabetes mellitus type 2 (RR 3.57, 95\% CI $2.83 ; 4.50)[3]$.

\section{Definition of the metabolic syndrome}

The metabolic syndrome refers to a clustering of risk factors rather than to a single disease, and there is currently no consensus about the definition. As a consequence, several organizations have developed their own working definitions [4-8]. Two definitions emphasized insulin resistance in their working definition $[4,5]$ and one definition emphasized abdominal obesity [8]. Although these definitions differ to some extent in the risk factors included and cut-off values used for specific risk factors, all definitions include low HDL-cholesterol, hypertriglyceridaemia, a measure of (abdominal) obesity, hyperglycaemia and hypertension. In this thesis, we used the definition of the National Cholesterol Education Program (NCEP) because this definition does not suggest an underlying cause of the metabolic syndrome and it is the most widely used definition in the literature [9]. It is based on criteria that are easily applicable in daily practice. According to this definition, the metabolic syndrome is present if at least three out of five characteristics are present: low HDLcholesterol concentration, hypertriglyceridaemia, abdominal obesity, hyperglycaemia, and hypertension [6]. In 2005, this NCEP definition was modified by including drug treatment for four out of the five characteristics (all but abdominal obesity) and by lowering the cut-off value for hyperglycaemia [10] (Table 1.1). In this thesis, we used the most recent 2005 definition if data about drug treatment were available, otherwise we used the 2001 definition.

\section{Prevalence of the metabolic syndrome}

Worldwide, the prevalence of the metabolic syndrome is high. In North and South America, Europe and India, the prevalence of the metabolic syndrome is at least $25 \%$ [11]. The prevalence in Southeast Asia is currently below $20 \%$ but it is expected to rise with the ageing of the population [11]. In the Netherlands, the prevalence according to the NCEP 2001 definition was $26 \%$ in older men and 19\% in older women (50-75 years) [12]. However, the prevalence according to the NCEP definition in a younger Dutch population had not been published previously. 
Table 1.1 Characteristics of the metabolic syndrome according to the National Cholesterol Education Program (NCEP) Adult Treatment Panel III

\begin{tabular}{lll}
\hline $\begin{array}{l}\text { Characteristics of the } \\
\text { metabolic syndrome }\end{array}$ & NCEP (2001) & \\
\hline Low HDL-cholesterol & $<1.04 \mathrm{mmol} / \mathrm{L}$ (men) & $<1.04 \mathrm{mmol} / \mathrm{L}$ (men) \\
& $<1.29 \mathrm{mmol} / \mathrm{L}$ (women) & $<1.29 \mathrm{mmol} / \mathrm{L}$ (women) \\
& Or drug treatment for low HDL-cholesterol \\
Hypertriglyceridaemia & $\geq 1.7 \mathrm{mmol} / \mathrm{L}$ & $\geq 1.7 \mathrm{mmol} / \mathrm{L}$ \\
& & Or drug treatment for hypertriglyceridaemia \\
Abdominal obesity & Waist circumference & Waist circumference \\
& $>102 \mathrm{~cm}$ (men) & $>102 \mathrm{~cm}$ (men) \\
& $>88 \mathrm{~cm}$ (women) & $>88 \mathrm{~cm}$ (women) \\
Hyperglycaemia & $\geq 6.1 \mathrm{mmol} / \mathrm{L}$ & $\geq 5.6 \mathrm{mmol} / \mathrm{L}$ \\
& & Or drug treatment for hyperglycaemia \\
Hypertension & $\geq 130 / \geq 85 \mathrm{mmHg}$ & $\geq 130 / \geq 85 \mathrm{mmHg}$ \\
& & Or drug treatment for hypertension \\
\hline
\end{tabular}

\section{Pathophysiology}

The different characteristics and cut-off values used in the working definition of the metabolic syndrome indicate that there is no consensus yet about its pathophysiology. Some researchers suggested that abdominal obesity plays a central role [8] but others suggested that insulin resistance is the central component [1].

\section{Insulin action and abdominal obesity}

The hormone insulin regulates glucose homeostasis through stimulation of glucose uptake in muscle tissue and adipose tissue, suppression of glucose production in the liver and of lipid release from adipose tissue (Figure 1.1a). Although muscle tissue accounts for the main part of glucose uptake, also adipose tissue is important in the regulation of insulin action $[13,14]$. Adipose tissue does not only store lipids but also has an endocrine function. Adipocytes can produce and secrete adipokines. In overweight or obese subjects abnormal levels of adipokines are secreted, which impairs the action of insulin. This abnormal secretion is at least partly caused by chronic inflammation within the adipose tissue. Target tissues and organs become less sensitive to insulin, which leads to insulin resistance.

\section{Insulin resistance}

Impairment of insulin action increases plasma glucose concentration because glucose uptake in muscle tissue and adipose tissue is reduced and glucose production in the liver is increased (Figure 1.1b). This increase in glucose concentration stimulates insulin production in the $\beta$-cells of the pancreas, to reduce plasma glucose concentrations [16]. 

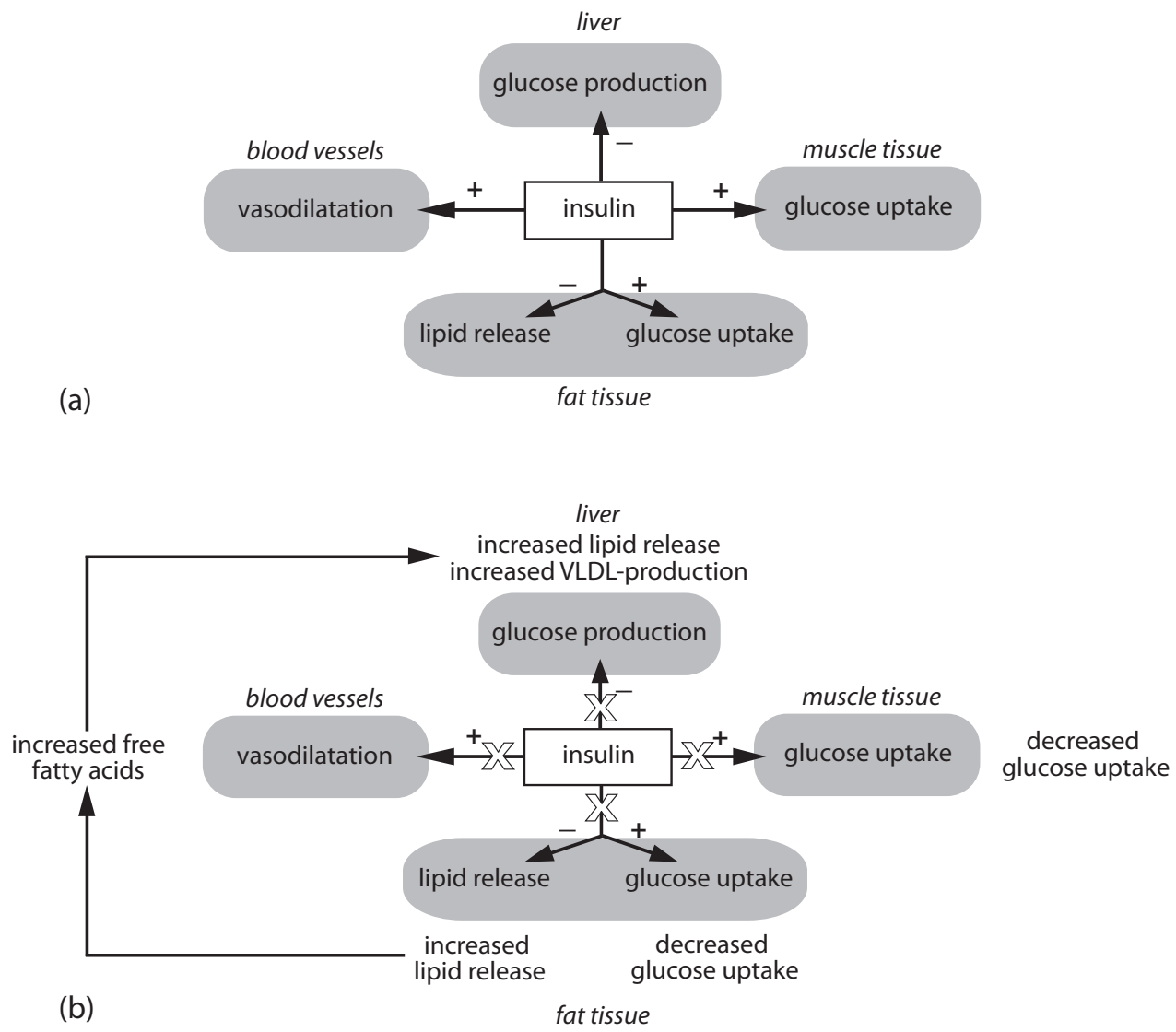

Figure 1.1 Physiological functions of insulin (a) and the consequences of insulin resistance (b). This figure is based on Olijhoek et al. [15] and was translated and modified with permission.

When this compensation mechanism is no longer adequate, hyperglycaemia develops. The impairment of the action of insulin also results in the loss of the vasodilatory effect of insulin, which may lead to hypertension [17]. In addition, the impairment of the action of insulin increases lipid release from adipose tissue. The increase of free fatty acids results in the production of more triglyceride-rich VLDL in the liver [18]. High triglyceride-rich VLDL concentration in the blood increases the exchange of triglycerides from VLDL for cholesterol esters from HDL. This exchange is mediated by cholesteryl ester transfer protein and results in triglyceride-rich HDL. Triglyceride-rich HDL is a substrate for hepatic lipase and lipoprotein lipase, which hydrolyze the triglycerides resulting in a smaller lipid-poor HDL particle. Thus, impairment of the action of insulin increases lipid transport in the plasma, which is the driving force of elevated triglyceride concentrations and reduced HDL-cholesterol concentrations. 


\section{Prevention of the metabolic syndrome}

Underlying risk factors for the metabolic syndrome are physical inactivity and an unhealthy diet. These risk factors are modifiable, and therefore lifestyle changes should have prime emphasis in the management of the metabolic syndrome [10]. In the Netherlands, a multidisciplinary guideline for cardiovascular risk management has been developed $[19,20]$. This guideline does not specifically provide lifestyle advice for persons with the metabolic syndrome, but provides advice for persons having a more than 5\% risk to die from cardiovascular disease in the next 10 years. This lifestyle advice comprises reducing obesity, increasing physical activity, stopping smoking, and eating a healthy diet. The recommended healthy diet is based on the most recent dietary guidelines of the Dutch Health Council [21] and contains less than $10 \%$ of total energy intake (energy-\%) of saturated fatty acids (SFA), less than 1 energy-\% of trans fatty acids, at least once a week fatty fish, minimal $200 \mathrm{~g}$ vegetables and 2 pieces of fruit daily, salt consumption of a maximum of $6 \mathrm{~g} /$ day and a maximum alcohol consumption of 2 glasses/ day for women and 3 glasses/day for men. This recommended diet has many similarities with a Mediterranean diet, which has been associated with a reduced risk of mortality [22] and might have favourable effects on the metabolic syndrome.

\section{A Mediterranean diet}

A Mediterranean diet refers to a dietary pattern as consumed in countries of the Mediterranean region during the early 1960s. The term Mediterranean diet suggests that there is one diet for all countries of the Mediterranean region. However, many differences in diet between Mediterranean countries exist [23]. Therefore, there is not just one Mediterranean diet but many Mediterranean diets. Because of this, the term "a Mediterranean diet" or "a Mediterranean type of diet" is more appropriate than "the Mediterranean diet". Common characteristics of a Mediterranean diet are use of olive oil as the main added lipid, abundant use of plant foods (fruits, vegetables, cereals, legumes, nuts, and seeds), moderate intake of fish and wine, and low to moderate consumption of dairy products and meat and poultry [24-26].

\section{A Mediterranean diet and the metabolic syndrome}

Observational studies have shown that a Mediterranean diet was associated with the metabolic syndrome in Southern Europe. A Mediterranean diet was inversely associated with the prevalence of the metabolic syndrome in Greek adults [27] and with the incidence of the syndrome in young Spanish subjects [28]. In Spanish adults living on the Canary Islands, no association between a Mediterranean diet and the prevalence of the metabolic syndrome was shown [29], although a favourable association with some of the characteristics of the metabolic syndrome was observed. No information is available about the association between a Mediterranean diet and the metabolic syndrome in other parts of Europe.

Two intervention studies in subjects at high cardiovascular risk have shown that a Mediterranean diet improves insulin sensitivity [30, 31]. Such an effect could not be demonstrated in healthy subjects [32]. The results of these intervention studies suggest that a Mediterranean diet may be more effective to improve insulin sensitivity 
in high-risk subjects than in healthy subjects. However, there is limited evidence from observational studies underpinning this suggestion. The only observational study reported so far, found an association between a Mediterranean diet and insulin sensitivity in healthy subjects with normal glucose tolerance but not in high-risk subjects with impaired glucose regulation or with diabetes mellitus type 2 [33]. As these findings contradict the results of the intervention studies, they need replication.

\section{A Mediterranean diet; is it the effect of monounsaturated fatty acids?}

A Mediterranean diet contains several components that potentially have a beneficial effect on characteristics of the metabolic syndrome. For example, olive oil, nuts, fish, dietary fibre, and alcohol may favourably affect serum lipids or insulin sensitivity [3438]. The high olive oil consumption in a Mediterranean diet is particularly interesting, because it is expected to have a beneficial effect on serum lipids as well as on insulin sensitivity. Olive oil is rich in monounsaturated fatty acids (MUFA) and replacing SFA with MUFA in the diet reduces total cholesterol, LDL-cholesterol, and triglyceride concentrations [39]. Replacing SFA with MUFA also increased insulin sensitivity in two intervention studies $[40,41]$. The two intervention studies that showed that a Mediterranean diet is able to improve insulin sensitivity also observed improvements in serum lipids $[30,31]$. However, these studies were not able to determine whether the effects of a Mediterranean diet were due to the high MUFA content of the diet or to the cumulative effect of the Mediterranean diet components.

\section{Outline of the thesis}

The main objective of this thesis was to study whether a Mediterranean diet affects the metabolic syndrome. In chapter 2 , the prevalence of the metabolic syndrome in the Netherlands was estimated. We studied whether a Mediterranean diet is associated with the metabolic syndrome in two observational studies. In chapter 3, the association between a Mediterranean diet and the metabolic syndrome in a study among European elderly subjects is described. In chapter 4, the association between a Mediterranean diet and markers of glucose metabolism and the metabolic syndrome in healthy and highrisk subjects is described. A controlled-feeding trial was carried out to study the effects of a Mediterranean diet on characteristics of the metabolic syndrome. In this trial, the effects of a Mediterranean diet on serum lipids and insulin sensitivity were compared with the effects of a high MUFA-diet and of a high SFA-diet. The results of this trial are presented in chapters 5 and 6 . In chapter 7, our findings will be summarised and critically discussed in view of the used methodology and findings from literature. 


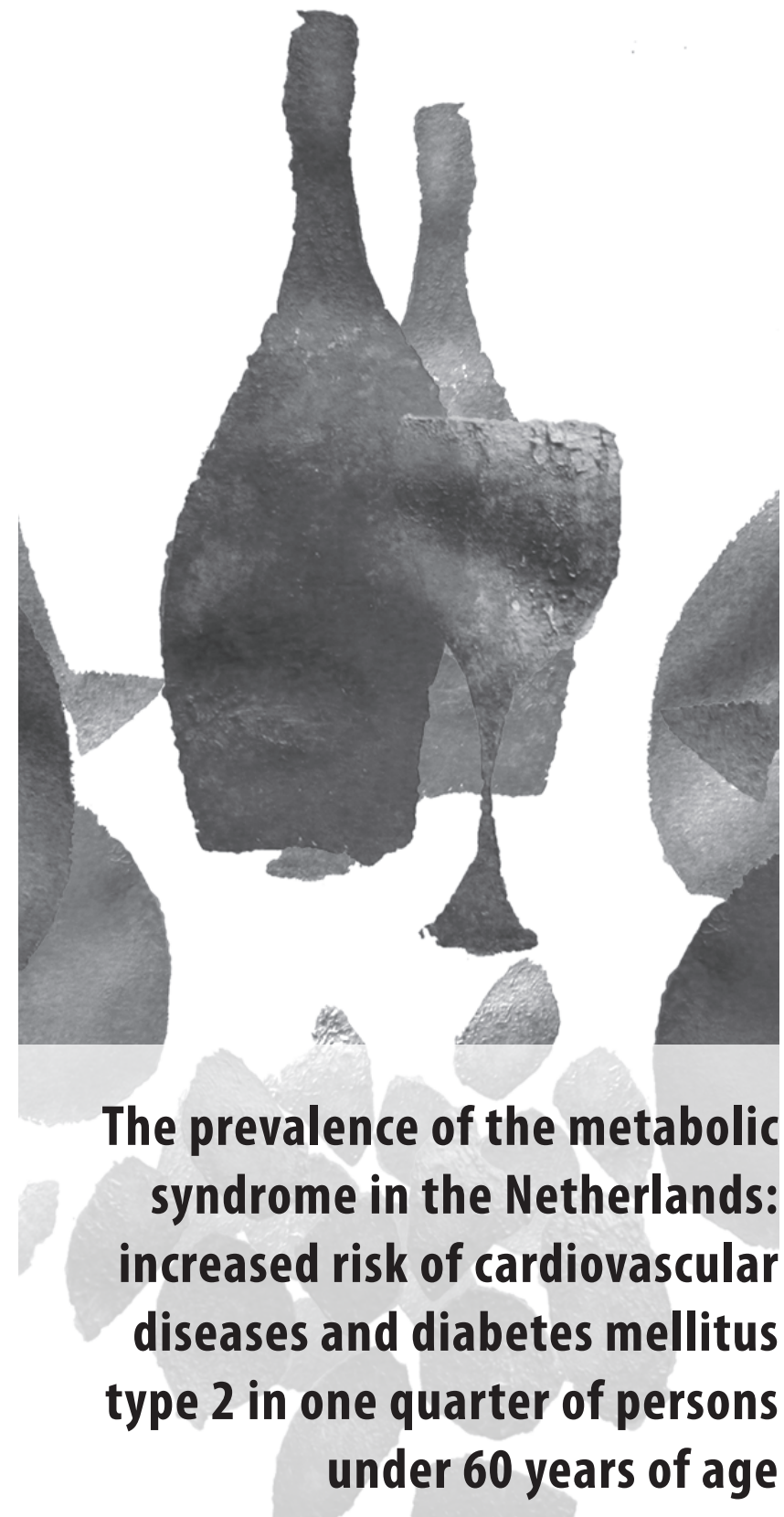

Marieke B. Bos, Jeanne H.M. de Vries, Bruce H.R. Wolffenbuttel, Hans Verhagen, Hans J.L. Hillege, Edith J.M. Feskens 


\section{Abstract}

Objective: To estimate the prevalence of the metabolic syndrome in the Netherlands in two populations in the age category 28-59 years and to compare this with the prevalence of hypercholesterolaemia in these populations.

Design: Descriptive.

Methods: Data from two Dutch population based studies were used: the 'Monitoring risk factors and health in the Netherlands' (MORGEN) study (1993-1995) and the 'Prevention of renal and vascular end-stage disease' (PREVEND) study (1998-1999). Subjects were identified as having the metabolic syndrome when they had at least three of the following five criteria according to the guideline of the 'National Cholesterol Education Program, 'Adult treatment panel III' (NCEP-2001): hyperglycaemia, low HDL-cholesterol concentration, hypertriglyceridaemia, hypertension or abdominal obesity. Final estimates were weighed according to the age- and sex distribution of the Dutch population during these survey years based on figures of the Dutch Central Bureau of Statistics.

Results: On average, the prevalence of the metabolic syndrome was $14 \% ; 19 \%$ in men and $12 \%$ in women in the MORGEN study, and $16 \%$ and $10 \%$ in men and women in the PREVEND study. The prevalence in subjects below 40 years of age was $12 \%$ for men and $5 \%$ for women. The prevalence increased considerably with age. Among subjects with both abdominal obesity and hypertension the prevalence was $68 \%$. Among subjects with 'hypertriglyceridaemic waist' the prevalence was $94 \%$. The prevalence of the metabolic syndrome showed little overlap with the prevalence of hypercholesterolaemia $(\geq 6.5$ $\mathrm{mmol} / \mathrm{l})$. In total, $26 \%$ of the subjects had either the metabolic syndrome or high total cholesterol concentrations.

Conclusion: Approximately one million Dutch adults below 60 years of age had the metabolic syndrome in the 1990s. Based on the total prevalence of the metabolic syndrome and hypercholesterolaemia, one quarter of the Dutch population younger than 60 years runs an increased risk of cardiovascular disease and diabetes mellitus type 2 .

\section{Introduction}

The metabolic syndrome (also known as insulin-resistance syndrome, dysmetabolic syndrome or syndrome $\mathrm{X}$ ), is an important risk factor for diabetes mellitus type 2 and cardiovascular disease [3, 12, 42-45]. The metabolic syndrome refers to a cluster of risk factors such as glucose tolerance, hypertension, obesity and dyslipidaemia.

In recent years, several definitions have been formulated for the metabolic syndrome, and they were recently summarised in this journal [15]. The definition formulated by the National Cholesterol Education Program, Adult Treatment Panel III (NCEP 2001) is widely used and is based on a number of diagnostic criteria that are easy to apply in clinical practice, such as blood pressure, waist circumference and fasting plasma concentrations of glucose, HDL-cholesterol and triglycerides [6]. The metabolic syndrome is diagnosed when three or more of the five criteria show abnormalities. This method does not emphasize any particular criterion. Neither does it suggest an underlying cause of the metabolic syndrome.

Particularly after the metabolic syndrome was included in the NCEP 2001 guidelines, the cluster of risk factors received a great deal of attention in the biomedical literature. Recently, however, its clinical relevance has been questioned [46]. For example, the metabolic syndrome appears to be a less reliable predictor of cardiovascular disease than the Framingham risk score [3,47]. Although the definition of the 
metabolic syndrome partly corresponds to the Framingham risk score and also to the SCORE risk function in the new 'clinical practice guideline for cardiovascular risk management in the Netherlands'[19], there are also differences. These relate mainly to the risk factors hypercholesterolaemia, age and smoking. Greater insight into the total size of the population with a high risk of cardiovascular disease can therefore be obtained by comparing the prevalence of the metabolic syndrome with that of hypercholesterolaemia. A good estimate of the prevalence of the metabolic syndrome provides information not only on the number of persons with a high risk of cardiovascular disease, but also on the risk of diabetes mellitus type 2 and the possible implications for public health. To a lesser extent, this is true for the other risk scores mentioned, partly because abdominal obesity is not included.

In 1990, the prevalence of the metabolic syndrome, when defined according to the NCEP-2001 criteria, was $26 \%$ in men and $19 \%$ in women between 50 and 74 years of age (the 'Hoorn Study') [12]. In the period 1993-1995, prevalence according to older criteria $[4,5]$ varied between $3 \%$ in women of $20-39$ years of age and $33 \%$ in men of 55 years and older [48]. In this study we assessed the prevalence of the metabolic syndrome, defined according to the NCEP-2001 criteria, in the age category 28-59 years in the most recent available representative random samples of the Dutch population. The samples dated from the period 1993-1999. We assessed the to which extent the nonbiochemical parameters (abdominal obesity and hypertension) and the combination of hypertriglyceridaemia and abdominal obesity (also known as 'hypertriglyceridaemic waist') [49] are good indicators of the metabolic syndrome. Finally, we studied the overlap with the prevalence of hypercholesterolaemia.

\section{Subjects and methods}

\section{Study population and weighting}

The study population comprised the participants in the project 'Monitoring of risk factors and health in the Netherlands' (MORGEN study) by the National Institute for Public Health and the Environment (RIVM) and the participants in the 'Prevention of Renal and Vascular End-stage Disease' (PREVEND) study by the University Medical Center Groningen (UMCG).

In the MORGEN study, in the period 1993-1997, a representative random sample of men and women between 20 and 59 years of age from the cities of Maastricht, Doetinchem and Amsterdam was examined each year [50, 51]. After the study, the fasting insulin and triglyceride concentrations were measured in 1378 stored blood samples taken in the period 1993-1995. For these additional measurements, an equal number of blood samples were selected by gender and 5-year age stratum.

The PREVEND study was a cohort study, for which the first screening took place in 1998 and 1999 [52]. All residents of the city of Groningen between 28 and 75 years of age were invited to take part in the screening. Respondents submitted a morning urine sample in which albumin secretion was measured. All persons with a high-normal albumin secretion (10-20 mg/l) or microalbuminuria (albumin secretion 20-200 mg/l) were then invited to take part in the study. A random sample was also taken among 
the people with non-abnormal albumin secretion. In the final study population, these groups were combined in proportion to the frequency of albuminuria (high, high-normal, normal) by means of weighting factors. Therefore, the data reflected the screened PREVEND population.

In order to combine the results of the two studies properly, the interval 28-59 years was taken as the age threshold for the study population of both the MORGEN study and the PREVEND study. Participants from whom fasting blood samples were taken, and in whom all criteria of the metabolic syndrome were measured, were included in the present data analysis; 1125 participants for the MORGEN study and 5508

Table 2.1 Characteristics of participants of the MORGEN and the PREVEND study in men and women, weighted according to the age distribution of the Dutch population in the year of the study (respectively 1 January 1994 and 1 January 1998)

\begin{tabular}{|c|c|c|}
\hline & $\begin{array}{l}\text { Mean (sd) } \\
\text { men }\end{array}$ & women \\
\hline \multicolumn{3}{|l|}{ MORGEN study (1993-1995) } \\
\hline $\mathrm{N}$ & 583 & 542 \\
\hline Age, years & $41.9(8.8)$ & $42.0(9.0)$ \\
\hline Glucose, $\mathrm{mmol} / \mathrm{L}$ & $5.6(1.1)$ & $5.2(0.8)$ \\
\hline Total cholesterol, mmol/L & $5.58(1.10)$ & $5.47(1.18)$ \\
\hline HDL-cholesterol, mmol/L & $1.18(0.30)$ & $1.47(0.37)$ \\
\hline Triglyceride, $\mathrm{mmol} / \mathrm{L}$ & $1.46(1.37)$ & $1.03(0.64)$ \\
\hline Systolic blood pressure, $\mathrm{mmHg}$ & $123.9(15.5)$ & $116.3(16.1)$ \\
\hline Diastolic blood pressure, $\mathrm{mmHg}$ & $80.9(10.0)$ & $76.1(10.3)$ \\
\hline Body mass index, $\mathrm{kg} / \mathrm{m}^{2}$ & $25.9(3.7)$ & $25.2(4.4)$ \\
\hline Waist circumference, $\mathrm{cm}$ & $93.7(10.7)$ & $81.9(11.6)$ \\
\hline Diabetes mellitus ${ }^{1}, \%$ & 1 & 0 \\
\hline Use of antihypertensives, \% & 3.8 & 3.4 \\
\hline \multicolumn{3}{|l|}{ PREVEND study² (1998-1999) } \\
\hline $\mathrm{N}$ & 2575 & 2933 \\
\hline Age, years & $42.2(9.3)$ & $42.3(8.5)$ \\
\hline Glucose, $\mathrm{mmol} / \mathrm{L}$ & $4.9(1.0)$ & $4.6(0.9)$ \\
\hline Total cholesterol, mmol/L & $5.57(1.21)$ & $5.38(1.03)$ \\
\hline HDL-cholesterol, mmol/L & $1.18(0.33)$ & $1.55(0.39)$ \\
\hline Triglyceride, $\mathrm{mmol} / \mathrm{L}$ & $1.55(1.33)$ & $1.13(0.64)$ \\
\hline Systolic blood pressure, $\mathrm{mmHg}$ & $128.0(14.4)$ & $117.7(14.6)$ \\
\hline Diastolic blood pressure, $\mathrm{mmHg}$ & $74.1(9.0)$ & $68.9(7.8)$ \\
\hline Body mass index, $\mathrm{kg} / \mathrm{m}^{2}$ & $25.7(3.7)$ & $25.2(4.3)$ \\
\hline Waist circumference, cm & $91.4(11.0)$ & $80.4(11.0)$ \\
\hline Diabetes mellitus'1, \% & 0.3 & 0.7 \\
\hline Use of antihypertensives, \% & 4.0 & 5.5 \\
\hline
\end{tabular}

MORGEN= 'Monitoring of risk factors and health in the Netherlands' [50, 51]; PREVEND='Prevention of Renal and Vascular End-stage Disease' [52].

${ }^{1}$ Assessed by use of diabetes medication or diet.

${ }^{2}$ The data from the PREVEND study were also weighted by study design. 
participants for the PREVEND study. There was no exclusion on the basis of medical history (e.g. diabetes mellitus). An overview of the characteristics of the participants can be found in (Table 2.1).

\section{Measurements and definitions}

Both studies used a standardized questionnaire that included information about age, diabetes, and use of medication (e.g. blood-glucose-lowering medication, antihypertensives and lipid-lowering medication). Height and weight were measured and the body mass index (in $\mathrm{kg} / \mathrm{m}^{2}$ ) was calculated. Waist circumference was measured halfway between the lower rib and the crest of the pelvis. In the MORGEN study, blood pressure was measured twice with a random-zero sphygmomanometer while the participant was in a seated position. The average of the two measurements was used in the calculations. In the PREVEND study, the participants' blood pressure was measured continuously for 10 minutes on two different days, when lying down (automatic Dinamap XL Model 9300; Johnson-Johnson Medical, Inc., Tampa, FL, U.S.). The average of the final two measurements was used in the calculations.

In the MORGEN study, concentrations of plasma glucose, total and HDL-cholesterol were measured by the Central Clinical Chemical Laboratory of the Erasmus Medical Center, Rotterdam, using standardized enzymatic methods. Triglyceride concentration was measured enzymatically using an Abbott Spectrum clinical analyser (Abbott Laboratories, Chicago, IL, U.S.) by the chemical laboratory of the Division of Human Nutrition, Wageningen University. In the PREVEND study, glucose, triglyceride, total and HDL-cholesterol concentrations were measured on site using the Kodak Ektachem 'dry chemistry' method (Eastman Kodak, Rochester, NY, U.S.). Bloodglucose concentrations were converted into equivalent plasma-glucose concentrations according to the Passing and Bablok method ( $(1.125 \times$ blood glucose concentration $)$ $-0.4375)$.

As mentioned, according to the NCEP 2001 definition, the metabolic syndrome is present when at least three of the following five criteria are met: hyperglycaemia (fasting glucose concentration $\geq 6.1 \mathrm{mmol} / \mathrm{l}$ ), HDL-cholesterol concentration $<1.04$ $\mathrm{mmol} / \mathrm{l}$ for men and $<1.29 \mathrm{mmol} / \mathrm{l}$ for women, hypertriglyceridaemia (triglyceride concentration $\geq 1.7 \mathrm{mmol} / \mathrm{l}$ ), hypertension (systolic blood pressure $\geq 130 \mathrm{mmHg}$ and/ or diastolic blood pressure $\geq 85 \mathrm{mmHg}$, or the use of antihypertensives), abdominal obesity (waist circumference $>102 \mathrm{~cm}$ for men and $>88 \mathrm{~cm}$ for women) [6]. The criterion for hypercholesteraemia was a total cholesterol concentration $\geq 6.5 \mathrm{mmol} / \mathrm{l}$, as recommended in the new 'clinical practice guideline for cardiovascular risk management in the Netherlands'.

\section{Statistics}

The results were weighted according to age (by 5-year age groups) and sex distribution of the Dutch population, according to the data of the Dutch Central Bureau of Statistics (CBS) in the year of the study (1 January 1994 for the MORGEN study and 1 January 1998 for the PREVEND study) and using the computer programme SAS version 9.0 (SAS Institute Inc., Cary, NC, U.S.). The data from the PREVEND study were weighted 
in proportion to the frequency of microalbuminuria, high-normal and normal urinary albumin concentration in the screened population, so that the final data reflected the screened population.

The prevalences observed in this study were extrapolated to the number of persons in the Dutch population who could be diagnosed with 'the metabolic syndrome' in the same year. Differences between men and women with regard to the prevalences of the metabolic syndrome and its individual criteria were tested using the $\chi 2$ test. The Cochrane-Armitage trend test, which is available in the SAS software, was used to test the prevalence of the metabolic syndrome by age category.

\section{Results}

\section{Metabolic syndrome}

The characteristics of the study population are shown in Table 2.1. The prevalence of the metabolic syndrome was 19\% in the MORGEN study and 16\% in the PREVEND study for men, and $12 \%$ and $10 \%$ respectively for women (Table 2.2 ). When the prevalences

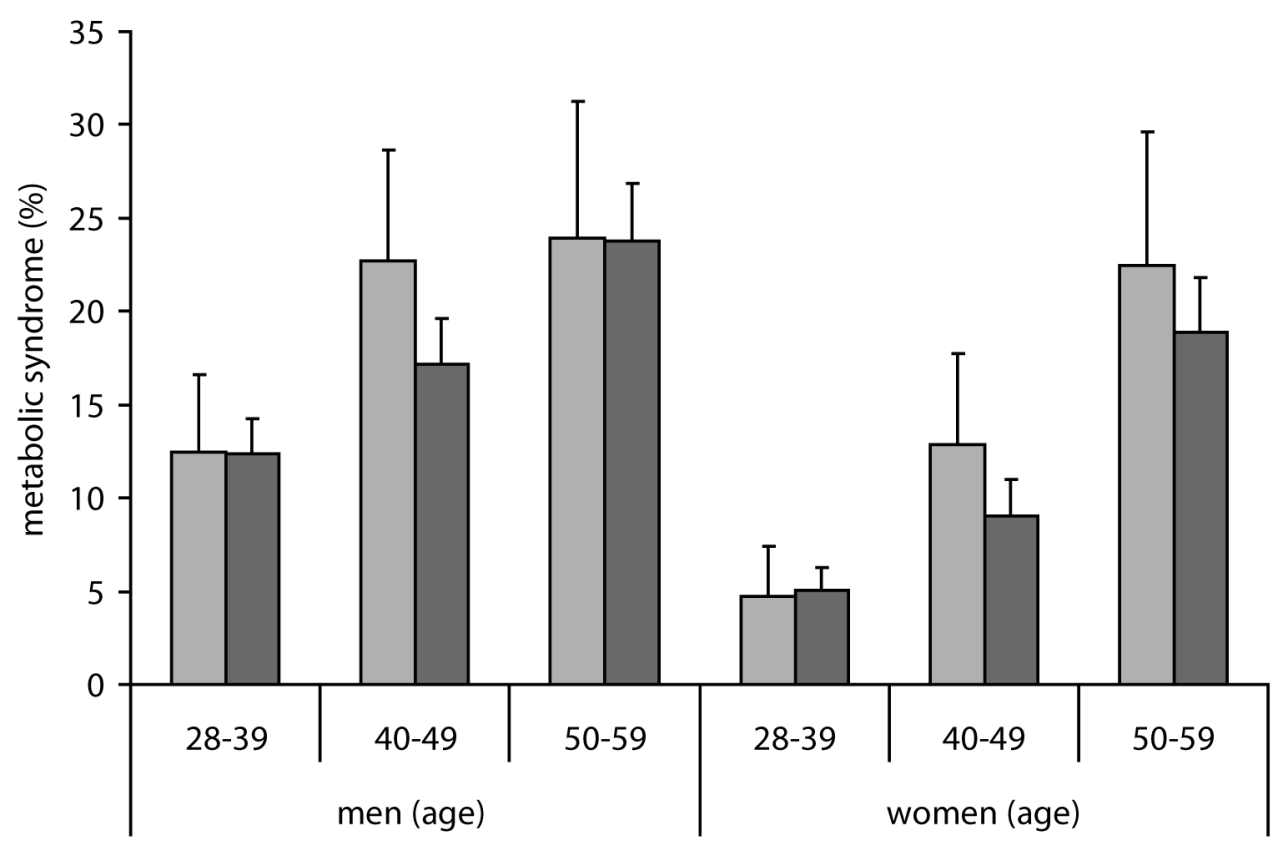

Figure 2.1 Prevalence of the metabolic syndrome according to the definition of the National Cholesterol Education Program (NCEP 2001) in men and women by age category in two studies ( $\quad$ :Monitoring of risk factors and health in the Netherlands' (MORGEN study) $(50,51)$ and $\square$ :Prevention of Renal and Vascular End-stage Disease' (PREVEND study) (52)), weighted according to the age distribution of the Dutch population in the year of the study (respectively 1 January 1994 and 1 January 1998). The vertical line bars indicate 95\%-confidence intervals. 
from these two studies were extrapolated to the Dutch population, this corresponded to approximately 1 million persons with the metabolic syndrome in the 1990s. Prevalence increased sharply with age (Figure 2.1 ). Testing revealed a significant age-related trend: for men this was $\mathrm{p}=0.001$ and $\mathrm{p}<0.001$ respectively in the MORGEN study and the PREVEND study, and for women $\mathrm{p}<0.0001$ and $\mathrm{p}<0.0001$. The prevalence of the metabolic syndrome was already considerable in persons under 40 years of age: $12 \%$ in men compared with $5 \%$ in women. Above the age of 50, the prevalence in men and women was comparably high (20-25\%).

More than half the number of men with abdominal obesity had the metabolic syndrome (MORGEN study: 58\%; PREVEND study: 64\%) (Table 2.3). The prevalence among women with abdominal obesity was slightly lower: 44 and 39\% respectively in the MORGEN study and the PREVEND study. The prevalence in men and women with abdominal obesity as well as hypertension was $68 \%$.

Separated into the three risk factors that are part of the metabolic syndrome and are measured in plasma, the prevalence of the metabolic syndrome was approximately $54 \%$ for persons with hypertriglyceridaemia and approximately $41 \%$ for men and $30 \%$ for women with a low HDL-cholesterol concentration. In contrast to the other results, a considerable difference was found between the two studies with regard to persons with hyperglycaemia; the prevalence of the metabolic syndrome was very high in the PREVEND study. For the group of participants with hypertriglyceridaemia as well as abdominal obesity, the prevalence of the metabolic syndrome varied between $86 \%$

Table 2.2 Prevalence of the metabolic syndrome and its characteristics according to the definition of the National Cholesterol Education Program (NCEP 2001) in men and women aged between 28 and 60 years in two studies (MORGEN study and PREVEND study), weighted according to the age distribution of the Dutch population in the year of the study (respectively 1 January 1994 and 1 January 1998)

\begin{tabular}{|c|c|c|c|c|}
\hline & \multicolumn{4}{|c|}{ Prevalence in \% (95\%-confidence interval) } \\
\hline & \multicolumn{2}{|c|}{ MORGEN study } & \multicolumn{2}{|c|}{ PREVEND study ${ }^{1}$} \\
\hline & men & women & men & women \\
\hline & $\mathrm{N}=583$ & $\mathrm{~N}=542$ & $\mathrm{~N}=2575$ & $N=2933$ \\
\hline Metabolic syndrome (NCEP 2001) & $19(16-22)$ & $12(9-15)^{2}$ & $16(15-17)$ & $10(9-11)^{2}$ \\
\hline Low HDL-cholesterol & $34(30-38)$ & $33(29-37)$ & $36(34-38)$ & $28(26-30)^{2}$ \\
\hline Hypertension $^{3}$ & $42(38-46)$ & $26(22-30)^{2}$ & $44(42-46)$ & $21(20-22)^{2}$ \\
\hline Abdominal obesity & $21(18-24)$ & $23(19-27)$ & $13(12-14)$ & $23(21-25)^{2}$ \\
\hline Hyperglycaemia & $20(17-23)$ & $9(7-11)^{2}$ & $5(4-6)$ & $3(2-4)^{2}$ \\
\hline Hypertriglyceridaemia & $24(21-27)$ & $13(10-16)^{2}$ & $29(27-31)$ & $13(12-14)^{2}$ \\
\hline
\end{tabular}

MORGEN = 'Monitoring of risk factors and health in the Netherlands' [50, 51]; PREVEND='Prevention of Renal and Vascular End-stage Disease' [52].

${ }^{1}$ The data from the PREVEND study were also weighted by study design.

${ }^{2}$ Significant difference between men and women $(p<0.001)$.

${ }^{3}$ Including use of antihypertensives. 
Table 2.3 Prevalence of the metabolic syndrome according to the definition of the National Cholesterol Education Program (NCEP 2001) in subgroups of subjects who fulfilled one or two of the criteria of the metabolic syndrome: men and women aged between 28 and 60 years in two studies (MORGEN study and PREVEND study), weighted according to the age distribution of the Dutch population in the year of the study (respectively 1 January 1994 and 1 January 1998)

\begin{tabular}{lllll}
\hline Criteria of the metabolic syndrome & \multicolumn{2}{l}{ Prevalence in \% (95\%-confidence interval) } & \\
& \multicolumn{2}{l}{ MORGEN study } & \multicolumn{2}{l}{ PREVEND study ${ }^{1}$} \\
& men & women & men & women \\
\hline Low HDL-cholesterol & $42(35-49)$ & $28(21-35)$ & $41(38-44)$ & $30(27-33)^{2}$ \\
Hypertension ${ }^{3}$ & $33(27-39)$ & $32(24-40)$ & $33(30-36)$ & $36(32-40)$ \\
Abdominal obesity & $58(49-67)$ & $44(35-53)$ & $64(59-69)$ & $39(35-43)^{2}$ \\
Hyperglycaemia & $48(39-57)$ & $44(30-58)$ & $70(62-78)$ & $82(73-91)$ \\
Hypertriglyceridaemia & $57(49-65)$ & $57(45-69)$ & $51(48-54)$ & $50(47-57)$ \\
Abdominal obesity + hypertension & $64(53-75)$ & $67(55-79)$ & $75(70-80)$ & $69(63-75)$ \\
Abdominal obesity + hypertriglyceridaemia & $97(92-100)$ & $93(84-100)$ & $96(93-99)$ & $86(81-91)^{2}$ \\
\hline
\end{tabular}

MORGEN= 'Monitoring of risk factors and health in the Netherlands' [50, 51]; PREVEND='Prevention of Renal and Vascular End-stage Disease' [52].

${ }^{1}$ The data from the PREVEND study were also weighted by study design.

${ }^{2}$ Significant difference between men and women $(p<0.001)$.

${ }^{3}$ Including use of antihypertensives.

for women in the PREVEND study and 97\% for men in the MORGEN study. The prevalence of hypercholesterolaemia (total cholesterol concentration $\geq 6.5 \mathrm{mmol} / \mathrm{l}$ ) was on average $17 \%$ based on both studies; this was higher than the prevalence of the metabolic syndrome (average 14\%). However, the overlap between the two risk groups was small. Both risk factors were present in $4 \%$ of the study population.

\section{Hypercholesterolaemia}

Of the participants, $13 \%$ had hypercholesterolaemia without the metabolic syndrome; $9 \%$ had the metabolic syndrome without hypercholesterolaemia (results not shown). The total high-risk group based on the metabolic syndrome and/or hypercholesterolaemia accounted for $26 \%$ of the study population.

\section{Discussion}

This study indicates that, in the 1990s, the prevalence of the metabolic syndrome in Dutch adults under the age of 60 was $15-22 \%$ in men and 9-15\% in women, i.e. approximately one million Dutch adults. Most of these adults did not have hypercholesterolaemia. Approximately one-quarter of persons below the age of 60 had a high risk on the basis of metabolic risk factors, including hypercholesterolaemia.

Another notable finding is the relatively high prevalence of the metabolic syndrome in men below the age of 40 . We attempted to obtain as accurate an impression as possible of the Dutch population, and the MORGEN study was set up as a representative random 
sample of that population. Although the study population of the PREVEND study was over selected with persons with microalbuminuria, the weighting of the results to the study design makes the study population a good representation of the screened population. Because the results of the MORGEN study generally corresponded to those of the PREVEND study, these two studies together provide a good picture of the Dutch population in the 1990s. It was not possible to adjust for the fact that, on average, participants in scientific studies have a higher socioeconomic status and are therefore probably healthier than the general population [53].

In recent years there has been an increase in the number of people in the Netherlands who are overweight and take little exercise $[54,55]$, which means that an increase in the number of people with the metabolic syndrome can also be expected. However, in this study we observed no difference between the prevalence of the metabolic syndrome in the MORGEN study carried out in 1993-1995 and the prevalence in the PREVEND study carried out in 1998 and 1999. There was no great difference in the prevalence of the metabolic syndrome in the age category 50-74 years between the 'Hoorn Study' from 1990, with prevalences of 26\% in men and 19\% in women [12] and the PREVEND study with prevalences of $24 \%$ and $26 \%$ respectively. This suggests in any case that prevalence did not change significantly during the 1990s.

In previous studies in Europe published in the early 1990s, in which the metabolic syndrome was defined according to WHO criteria, prevalence was found to be $15 \%$ in the population of 30-89 years of age [42], and 7-36\% in men and 5-22\% in women aged 40-54 years [48]. As in the present study, the prevalence of the metabolic syndrome in these European studies was higher in men than in women, and increased sharply with age. However, when assessing gender differences, the age of the study populations can have a distorting effect. In our study, the prevalence of the metabolic syndrome in women increased sharply with age, and the difference in men and women was more prominent in the younger age categories than in the older age categories (Figure 2.1). This may be due to hormonal changes, given that the menopause is accompanied by an increase in abdominal fat deposit [56].

Doubts have been raised with regard to the value of the entity 'metabolic syndrome' in clinical practice [46]. Some studies have found that the metabolic syndrome has an added value in relation to existing risk factors in predicting the risk of cardiovascular disease [57]. However, other studies show no added value in relation to the Framingham risk score and have found that the number of risk factors provides more information in terms of predicting cardiovascular disease [12]. This assumes that, in practice, it is possible to measure all the separate risk factors, and that this will be done. However, the metabolic syndrome comprises more than the criteria of the definition alone, such as sub-chronic inflammation, small dense LDL and reduced clotting potential, which are not routinely measured [58]. In that case, the diagnosis of the metabolic syndrome can be seen as a simple means of recognising a more extensive cluster of risk factors [58]. Given the clustering that is also apparent in the Dutch study populations, it is clear that, in the case of individuals with one or two criteria of the metabolic syndrome, it is necessary to be alert to the presence of other risk factors. Our study showed that more than half of all men and approximately $40 \%$ of women 
with abdominal obesity have at least two other criteria of the metabolic syndrome, and therefore the metabolic syndrome (Table 2.3). Approximately two-thirds of men and women with abdominal obesity as well as hypertension have at least one other criteria of the metabolic syndrome.

This study showed a high prevalence of the metabolic syndrome in Dutch adults below 60 years of age, but there was little overlap with the diagnosis 'hypercholesterolaemia'. In total, one-quarter of Dutch adults below the age of 60 have an increased risk of cardiovascular disease or diabetes mellitus type 2. This information is relevant for clinical practice and policy in terms of forecasting the demand for care, but also highlights the need for prevention (e.g. through lifestyle changes).

\section{Acknowledgements}

This study would not have been possible without the assistance of the epidemiologists, physicians and researchers of the MORGEN and PREVEND studies, who helped to compile the data. Prof. C.P.G.M. de Groot and Prof. F.J. Kok commented on previous versions of the manuscript. Conflicts of interest disclosures: none.

Financial support: Netherlands Heart Foundation (2003B068). The MORGEN study was financed by the Ministry of Health, Welfare and Sport, and the National Institute for Public Health and the Environment (RIVM). The PREVEND study was financially supported by the Dutch Kidney Foundation (E033). 


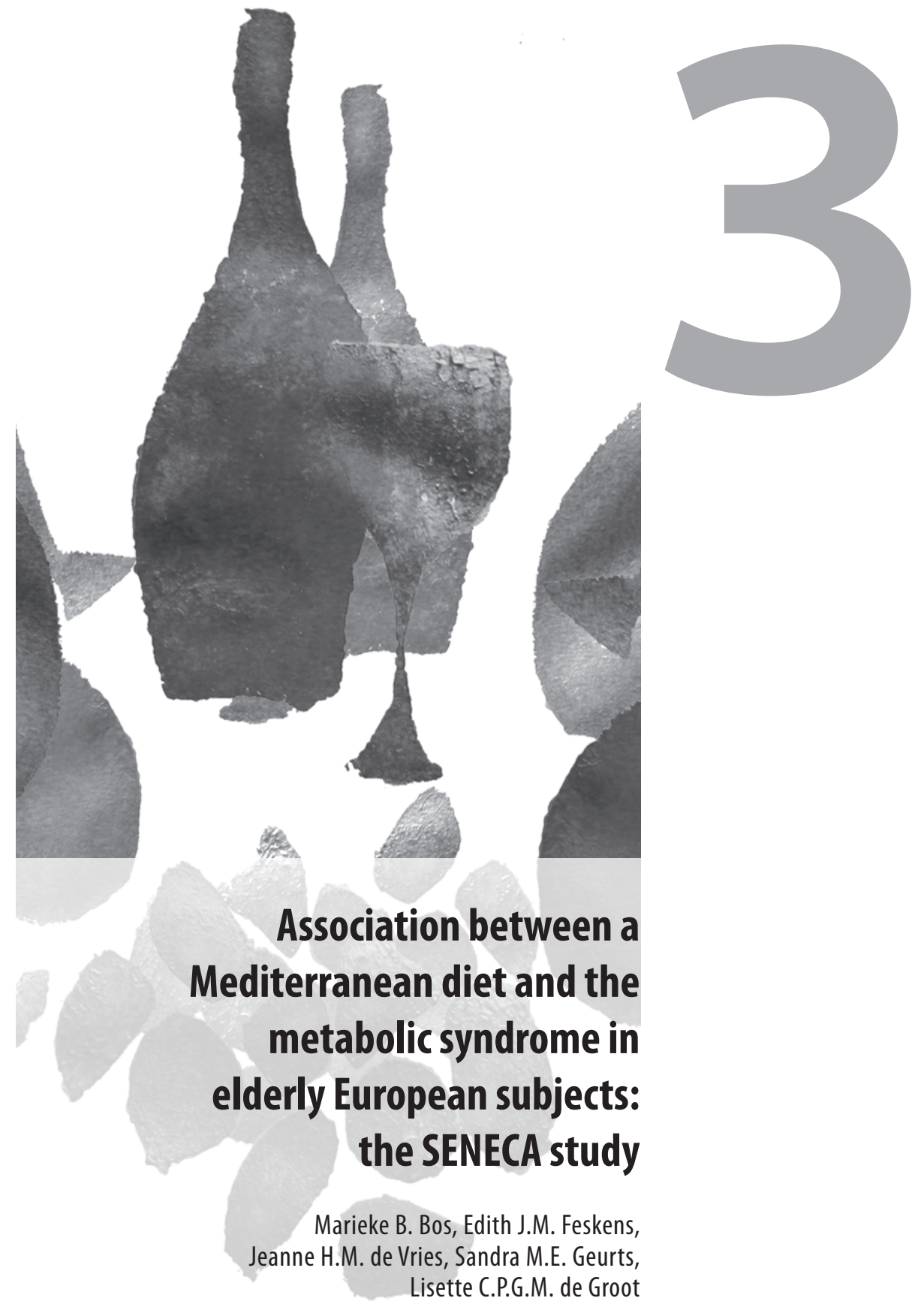




\begin{abstract}
The relationship between a Mediterranean diet and the metabolic syndrome has been scarcely studied in elderly populations. We analysed the association between a Mediterranean diet and the metabolic syndrome and its characteristics in a European elderly population using baseline data of the Survey in Europe on Nutrition and the Elderly, a Concerted Action (SENECA).

The study population included 627 men and 631 women, aged between 70 and 76 years of 10 European countries. Adherence to a Mediterranean diet was assessed by the Mediterranean diet score (MDS, range 0 through 9). All analyses were adjusted for study centre. Analyses on waist circumference were also adjusted for sex and physical activity. Although not statistically significant, elderly subjects with good adherence to a Mediterranean diet (MDS $>4$ (median) ) had a lower prevalence of the metabolic syndrome (prevalence ratio $0.81,95 \% \mathrm{CI} 0.65 ; 1.03$ ) and tended to have smaller waist circumference $(-1.1 \mathrm{~cm}, 95 \% \mathrm{CI}-2.4 ; 0.3)$ than elderly subjects with poor adherence. Good adherence to a Mediterranean diet was associated with higher HDL-cholesterol $(0.05 \mathrm{mmol} / \mathrm{L}, 95 \% \mathrm{CI}$ $0.00 ; 0.10)$ and lower triglyceride concentrations $(-0.12 \mathrm{mmol} / \mathrm{L}, 95 \% \mathrm{CI}-0.24 ; 0.00)$ but not with measures of insulin sensitivity.

These results implicate that the prevalence of the metabolic syndrome is lower in elderly people with good adherence to a Mediterranean diet.
\end{abstract}

\title{
Introduction
}

A Mediterranean diet has been associated with reduction in mortality [22] and with several protective factors for cardiovascular disease [9]. The Mediterranean diet is characterized by use of olive oil as the main added lipid, abundant use of plant foods (fruits, vegetables, cereals, legumes, nuts, and seeds), moderate intake of fish and wine, and low to moderate consumption of dairy products and meat and poultry [24-26]. It was suggested that adoption of a Mediterranean diet may also prevent people from developing the metabolic syndrome [59]. This syndrome is a risk factor for cardiovascular disease and diabetes mellitus type $2[3,42,43]$ and is present if at least three of five characteristics are present: low HDL-cholesterol concentration, hypertriglyceridaemia, abdominal obesity, hyperglycaemia, and hypertension [6]. Intervention studies in subjects at high cardiovascular risk showed that a Mediterranean diet reduced the prevalence of the metabolic syndrome [30, 60]. In addition, observational studies showed that a Mediterranean diet was inversely associated with the incidence of the metabolic syndrome [28] and the incidence of diabetes mellitus type 2 [61] in Spanish adults.

The prevalence of the metabolic syndrome is high in elderly populations, therefore this age group may benefit the most from adoption of a Mediterranean diet. However, the relationship between a Mediterranean diet and the metabolic syndrome has scarcely been studied in elderly populations [62]. We analysed the association between a Mediterranean diet and the metabolic syndrome and its characteristics in a study among European elderly subjects. As reduced insulin sensitivity is suggested to be one the underlying mechanism of the metabolic syndrome [1], we also investigated the association between a Mediterranean diet and insulin sensitivity. 


\section{Subjects and Methods}

\section{Subjects}

We analysed baseline data of the Survey in Europe on Nutrition and the Elderly, a Concerted Action (SENECA). In 1988 and 1989, individuals who were born between 1913 and 1918 and living in small towns across Europe were invited for participation in the SENECA study. The towns had a stable population with 10,000-20,000 inhabitants and a socioeconomic and population structure representative for its home country [63]. Psycho-geriatric patients living in nursing homes, persons who were not fluent in the country's language or not able to independently answer questions were excluded from participation. From a subgroup of 1554 SENECA subjects blood samples for serum lipid measurements and glucose and insulin measurements were available [64]. These subjects lived in 14 towns of 10 countries: Belgium: Hamme; Denmark: Roskilde; France: Haguenau and Romans; Hungary: Monor; the Netherlands: Culemborg; Norway: Elverum; Switzerland: Yverdon, Burgdorf, and Bellinzona; Greece: Markopoulou and Anogia-Archanes; Portugal: Vila Franca de Xira; Spain: Betanzos.

\section{Assessment of dietary intake}

The usual dietary intake of the subjects during the month preceding enrolment was assessed by trained dieticians using the dietary history method [65]. Food consumption data were arranged into food groups following the EUROCODE classification system [66]. We used the Mediterranean diet score (MDS) [25] to assess the degree of adherence to a Mediterranean diet. This MDS consists of 9 components: ratio of monounsaturated to saturated fatty acids (MUFA to SFA); vegetables; legumes; fruits plus nuts; cereals; fish; meat plus poultry; dairy products; and alcohol. In our study, we had to slightly modify the MDS because some of these food groups were combined according to the EUROCODE system. The food group 'vegetables' was replaced with 'vegetables and potatoes', the group 'legumes' with 'legumes, nuts and seeds', and the group 'fruits plus nuts' with 'fruits.' For the components MUFA to SFA ratio, vegetables and potatoes, legumes, nuts and seeds, fruits, cereals, and fish a value of 1 was assigned to subjects whose intake was above the sex specific median, and 0 to others (Table 3.1). For meat and poultry, and dairy products, a value of 1 was assigned to persons whose intake was below the sex specific median, and 0 to others. A value of 1 was also assigned to men who consumed between 10 and $50 \mathrm{~g}$ alcohol per day and to women who consumed between 5 and $25 \mathrm{~g}$ alcohol per day. The medians were adjusted for energy intake (10.5 MJ for men and 8.4 MJ for women). A MDS above the median was used to define good adherence to a Mediterranean diet.

Besides the original MDS we also analysed our data with two modified Mediterranean diet scores that were previously used within the SENECA study. In the first modified score, optimal intake for dairy products was defined as between the 25th and 75th percentile values instead of an intake below the median. In addition, for women the upper limit for meat and poultry was defined as $130 \mathrm{~g} /$ day instead of the median intake $[67,68]$. In the second modified score, alcohol was not included in the MDS but the statistical models were adjusted for alcohol intake [69]. 
Table 3.1 Sex specific cut-off values (based on medians of the population) and scoring for components of the Mediterranean diet score

\begin{tabular}{lllll}
\hline Components of the Mediterranean diet score & $\begin{array}{l}\text { Energy adjusted }{ }^{1} \text { sex specific } \\
\text { cut-off values }\end{array}$ & Scoring \\
\hline & Male & Female & \\
MUFA/SFA ratio & 0.98 & 1.00 & $>$ median & 1 (else 0) \\
Vegetables and potatoes, g/day & 301 & 261 & $>$ median & 1 (else 0) \\
Legumes, nuts, seeds, g/day & 4.0 & 2.4 & $>$ median & 1 (else 0) \\
Fruits, g/day & 201 & 234 & $>$ median & 1 (else 0) \\
Cereals, g/day & 230 & 191 & $>$ median & 1 (else 0) \\
Fish, g/day & 29 & 28 & $>$ median & 1 (else 0) \\
Meat and poultry, g/day & 135 & 102 & $<$ median & 1 (else 0) \\
Dairy products, g/day & 323 & 302 & $<$ median & 1 (else 0) \\
Alcohol, g/day & $10-50$ & $5-25$ & Within range 1 (else 0) \\
\hline
\end{tabular}

Abbreviation: monounsaturated/saturated fatty acids (MUFA/SFA).

${ }^{1}$ After adjustment for energy consumed (10.5 MJ for men and 8.4 MJ for women).

\section{Metabolic syndrome}

The metabolic syndrome is present if at least three of five characteristics are present: low HDL-cholesterol concentration (HDL-cholesterol concentration $<1.04 \mathrm{mmol} / \mathrm{L}$ for men and $<1.29 \mathrm{mmol} / \mathrm{L}$ for women), hypertriglyceridaemia (triglyceride concentration $\geq 1.7 \mathrm{mmol}$ ), abdominal obesity (waist circumference $>102 \mathrm{~cm}$ for men and $>88 \mathrm{~cm}$ for women), hyperglycaemia (glucose concentration $\geq 6.1 \mathrm{mmol} / \mathrm{L}$ ), and hypertension (systolic blood pressure $\geq 130 \mathrm{mmHg}$ and/or diastolic blood pressure $\geq 85 \mathrm{mmHg}$ ) [6]. Abdominal obesity was assessed by measurement of waist circumference to the nearest $0.1 \mathrm{~cm}$ midway between the lower rib margin and the iliac crest at the end of gentle expiration. Blood samples were taken between 7.30 and 9.30 am while the subject was in a fasting state. Serum HDL-cholesterol and triglyceride concentrations were measured by the laboratory of the Division of Human Nutrition, Wageningen University, Wageningen, the Netherlands [70]. HDL-cholesterol was measured after apo- $\beta$-lipoprotein precipitation with Dextran sulphate- $\mathrm{Mg}^{2+}$ by the enzymatic CHOP-PAP method. After elimination of free glycerol from the samples, triglyceride concentration was measured by an enzymatic colorimetric method using BoehringerMannheim reagents. Plasma glucose concentration was measured by the hexokinase method using Hitachi 911 auto-analyser. As blood pressure was not measured, we had to use a proxy measure for hypertension to enable the estimation of the prevalence of the metabolic syndrome. Data on self-reported hypertension that were available from a questionnaire were used as proxy measure.

Insulin resistance has been suggested to be the underlying metabolic disturbance of the metabolic syndrome [1]. Therefore, we also addressed individual measurements of insulin sensitivity such as insulin concentration and insulin resistance. Plasma insulin concentration was measured by using enzyme immunoassay (Boehringer-Mannheim, 
Mannheim, Germany) and insulin resistance was estimated using homeostatic model assessment insulin resistance (HOMA-IR) from glucose and insulin concentrations (http://www.dtu.ox.ac.uk/).

\section{Other measurements}

Information on education level (low or high), smoking status (non-smokers, former smokers or current smokers), and presence of chronic disease (including diabetes, ischaemic heart disease and stroke) was collected using questionnaires. The Voorrips questionnaire, designed to assess physical activity level in elderly people, was used to obtain information on habitual physical activity [71]. Subjects were divided into three groups according to sex specific tertiles: low, moderate, or high physical activity level.

\section{Statistics}

After exclusion of subjects because of missing data on outcome variables or potential confounders $(n=286)$, data collected from 1258 subjects were used for statistical analysis. This subgroup was not substantially different from the source population of the SENECA in age and sex distribution and anthropometric measurements. Differences in characteristics between subjects with good and poor adherence to a Mediterranean diet were tested with Chi-square tests and Students' t-tests. A Cox-regression model with robust error variance was used to estimate the prevalence ratio (PR) of the metabolic syndrome for subjects with good adherence to the Mediterranean diet compared with subjects with poor adherence [72]. A linear regression model was applied to estimate the association between a Mediterranean diet and HDL-cholesterol and triglyceride concentrations, waist circumference, glucose and insulin concentrations, and HOMAIR. The variables age, sex, physical activity level, type of education, presence of chronic disease, smoking status, and study centre were considered to be potentially confounding variables. As waist circumference is considered to be an intermediate in the relation between a Mediterranean diet and the outcome measures, we did not adjust our analysis for waist circumference. Study centre was a confounder and all models were adjusted for it. The models with waist circumference as dependent variable were also adjusted for sex and physical activity level. The analyses were performed using the statistical package SAS, version 9.1 (SAS Institute Inc., Cary, NC, USA).

\section{Results}

In this elderly European study population, subjects with good and poor adherence to a Mediterranean diet were of similar age and sex (Table 3.2). Subjects with good adherence to a Mediterranean diet had higher physical activity scores, lower education level and more chronic disease than subjects with poor adherence. The Mediterranean diet score was significantly higher in the countries of the Mediterranean region than in the non-Mediterranean region $(\mathrm{p}<0.0001)$ (Table 3.3).

The prevalence of the metabolic syndrome was lower in subjects with good adherence to a Mediterranean diet than in subjects with poor adherence (PR 0.81, 95\%CI 0.65; $1.03)$, however, this association was not significant at the $5 \%$ level $(\mathrm{p}=0.08)$. In addition, 
Chapter 3 The SENECA study

Table 3.2 Baseline characteristics of the subjects of the SENECA study

\begin{tabular}{lllr}
\hline & \multicolumn{3}{c}{ Mediterranean diet score } \\
& Poor adherence (MDS $\leq 4)$ & Good adherence (MDS >4) & p-value \\
\hline N & 667 & 591 & 0.24 \\
Men, N (\%) & $322(48)$ & $305(52)$ & 0.33 \\
Age, years, mean (sd) & $73.5(1.7)$ & $73.4(1.8)$ & 0.07 \\
Physical activity score ${ }^{2}$ & $11.8(5.9,19.4)$ & $13.7(6.6,23.2)$ & $<0.01$ \\
Type of education & & & \\
$\quad$ Higher education, N (\%) & $260(39)$ & $185(31)$ & 0.03 \\
$\quad$ Lower education, N (\%) & $407(61)$ & $406(69)$ & 0.30 \\
Chronic disease, N (\%) & $487(73)$ & $462(78)$ & 0.22 \\
$\quad$ Diabetes mellitus, N (\%) & $51(8)$ & $58(10)$ & 0.30 \\
$\quad 1$ Ischaemic heart disease, N (\%) & $112(17)$ & $101(17)$ & $<0.01$ \\
$\quad$ Stroke, N (\%) & $18(3)$ & $18(3)$ & 0.83 \\
Smoking status & & & $<0.01$ \\
$\quad$ Non-smoking, N (\%) & $326(49)$ & $345(58)$ & $166(28)$ \\
$\quad$ Current smoker, N (\%) & $191(29)$ & $80(14)$ & \\
$\quad$ Former smoker, N (\%) & $150(22)$ & & \\
\hline
\end{tabular}

Abbreviations: Mediterranean diet score (MDS).

${ }^{1}$ Median (interquartile range).

Table 3.3 Mean Mediterranean diet score by study centres in Mediterranean and nonMediterranean regions

\begin{tabular}{llrr}
\hline & & & Mediterranean diet score \\
Country & Study centre & $N$ & Mean (sd) \\
\hline Non-Mediterranean region & & 751 & $3.7(1.5)$ \\
Belgium & Hamme & 86 & $3.7(1.4)$ \\
Denmark & Roskilde & 155 & $3.1(1.4)$ \\
France & Hagenau & 54 & $4.7(1.5)$ \\
Hungary & Monor & 14 & $3.8(1.8)$ \\
The Netherlands & Culemborg & 192 & $3.6(1.4)$ \\
Norway & Elverum & 54 & $2.9(1.3)$ \\
Switzerland & Yverdon & 151 & $4.5(1.4)$ \\
Switzerland & Burgdorf & 45 & $3.3(1.5)$ \\
Mediterranean region & & 507 & $5.3(1.4)$ \\
France & Romans & 37 & $4.9(1.6)$ \\
Greece & Markopoulou & 25 & $5.9(1.2)$ \\
Greece & Anogia Archanes & 48 & $5.7(1.0)$ \\
Portugal & Vila Franca de Xira & 193 & $5.3(1.3)$ \\
Spain & Betanzos & 159 & $5.2(1.5)$ \\
Switzerland & Bellinzona & 45 & $4.6(1.6)$ \\
\hline
\end{tabular}


Table 3.4 Differences in characteristics of the metabolic syndrome and insulin sensitivity between subjects with good adherence to a Mediterranean diet (Mediterranean diet score $(M D S)>4$ ) compared with subjects with poor adherence (MDS $\leq 4)$

\begin{tabular}{|c|c|c|c|c|}
\hline \multirow{2}{*}{$\begin{array}{l}\text { Characteristics of the metabolic } \\
\text { syndrome and insulin sensitivity }\end{array}$} & \multicolumn{2}{|c|}{ Mediterranean diet score ${ }^{1}$} & \multirow{2}{*}{$\begin{array}{c}\text { Mean difference }{ }^{1} \\
\text { Good-poor }\end{array}$} & \multirow[t]{2}{*}{$95 \% \mathrm{Cl}$} \\
\hline & $\begin{array}{l}\text { Poor adherence } \\
\text { (MDS } \leq 4)\end{array}$ & $\begin{array}{l}\text { Good adherence } \\
\quad(\mathrm{MDS}>4)\end{array}$ & & \\
\hline & Mean (se) & Mean (se) & & \\
\hline $\mathrm{N}$ & 667 & 591 & & \\
\hline HDL-cholesterol, $\mathrm{mmol} / \mathrm{L}$ & $1.27(0.01)$ & $1.32(0.02)$ & 0.05 & $0.00 ; 0.10$ \\
\hline Triglyceride, $\mathrm{mmol} / \mathrm{L}$ & $1.51(0.04)$ & $1.39(0.04)$ & -0.12 & $-0.24 ; 0.00$ \\
\hline Waist circumference ${ }^{2}, \mathrm{~cm}$ & $93.7(0.4)$ & $92.6(0.5)$ & -1.1 & $-2.4 ; 0.3$ \\
\hline Glucose, $\mathrm{mmol} / \mathrm{L}$ & $6.06(0.07)$ & $6.03(0.08)$ & -0.03 & $-0.25 ; 0.19$ \\
\hline Insulin, pmol/L & $74.15(1.93)$ & $71.75(2.07)$ & -2.40 & $-8.33 ; 3.53$ \\
\hline HOMA-IR & $1.44(0.04)$ & $1.39(0.04)$ & -0.05 & $-0.17 ; 0.06$ \\
\hline
\end{tabular}

Abbreviations: Mediterranean diet score (MDS), homeostatic model assessment insulin resistance (HOMA-IR). ${ }^{1}$ Adjusted for study centre.

${ }^{2}$ Additionally adjusted for sex and physical activity level.

subjects with good adherence to a Mediterranean diet had significantly higher HDLcholesterol and lower triglyceride concentrations than subjects with poor adherence (Table 3.4). Subjects with good adherence to a Mediterranean diet tended to have smaller waist circumference than subjects with poor adherence $(\mathrm{p}=0.11)$. No significant associations were found between a Mediterranean diet and concentrations of glucose and insulin or HOMA-IR.

The use of a modified MDS $[67,68]$ that included alternative cut-off points for dairy products and meat an poultry led to similar conclusions as the original MDS. The use of a modified MDS [69] that did not include alcohol in the score resulted in lower glucose $(-0.19 \mathrm{mmol} / \mathrm{L}, 95 \% \mathrm{CI}-0.41 ; 0.04)$ and insulin concentrations $(-5.09 \mathrm{pmol} / \mathrm{L}$; 95\%CI $-11.19 ; 1.02)$ and HOMA-IR $(-0.11 ; 95 \%$ CI -0.23 ; 0.01$)$ in subjects with good adherence to this Mediterranean diet than in subjects with poor adherence, however these associations were not statistically significant.

When we investigated the MDS components separately in relation to the characteristics of the metabolic syndrome, HDL-cholesterol concentration was significantly higher in subjects with a dairy consumption below the median of the population (Table 3.5). Triglyceride concentration tended to be lower in subjects with meat and poultry consumption below the median of the population $(\mathrm{p}=0.06)$. Meat and poultry consumption below the median was also associated with smaller waist circumference $(\mathrm{p}<0.01)$. Although no associations were found between a Mediterranean diet with glucose, we observed that low meat and poultry consumption was significantly associated $(\mathrm{p}<0.01)$ with lower glucose concentration. 
Chapter 3 | The SENECA study

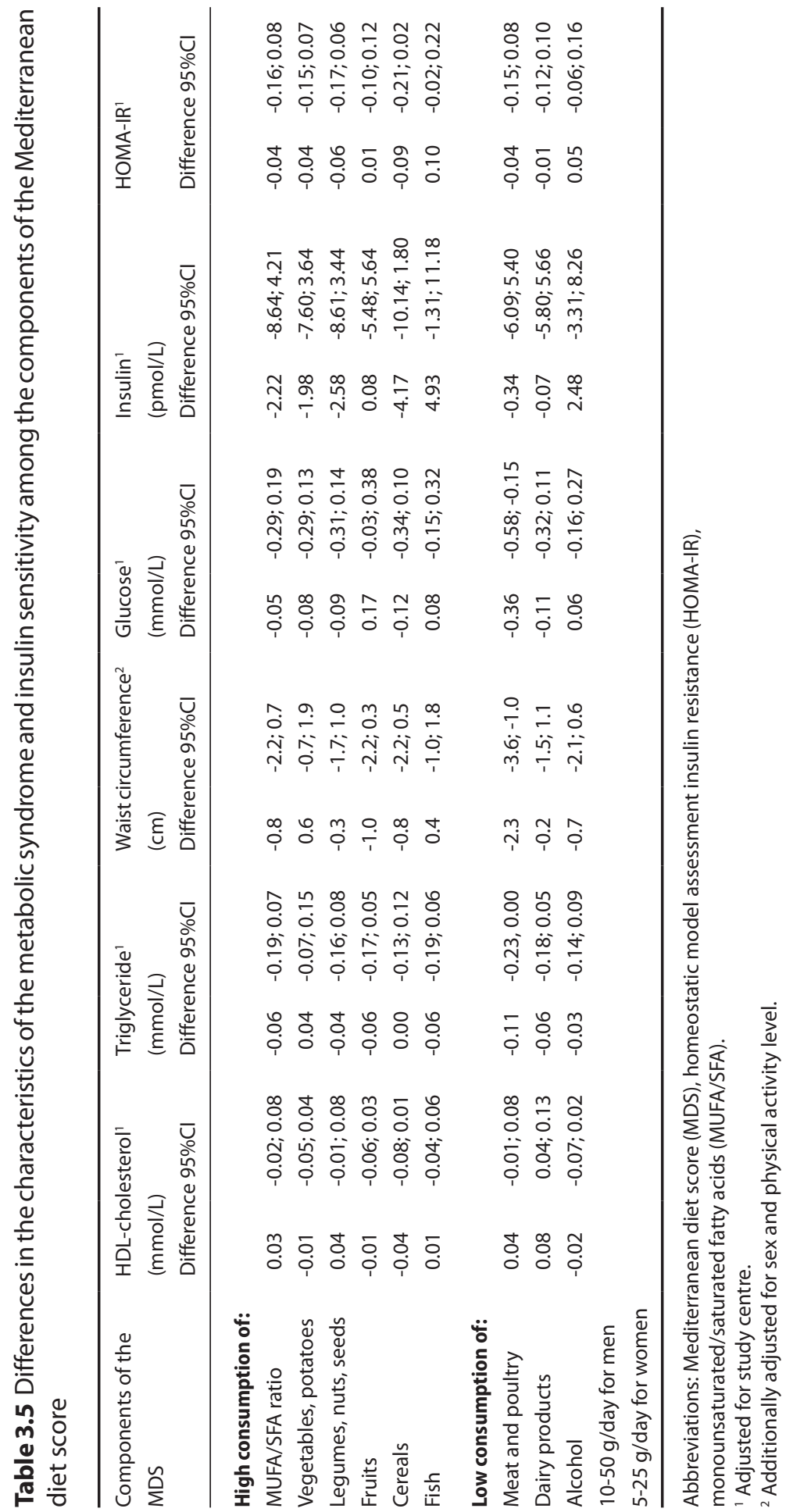




\section{Discussion}

Good adherence to a Mediterranean diet was associated with higher HDL-cholesterol and lower triglyceride concentrations but not with measures of insulin sensitivity in European elderly subjects. Although not statistically significant, elderly subjects with good adherence to a Mediterranean diet had a lower prevalence of the metabolic syndrome and tended to have smaller waist circumference than elderly subjects with poor adherence.

To our knowledge, the relation between a Mediterranean diet and HDL-cholesterol and triglyceride concentrations has only scarcely been studied in apparently healthy elderly populations [62]. Two Spanish cross-sectional studies in an on average younger (6-75 years or 18-75 years) study populations did not show an association between a Mediterranean diet and triglyceride concentration [29, 73], however, an association with higher HDL-cholesterol concentration was found in one of the studies [73]. Several intervention studies showed that a Mediterranean diet increased HDL-cholesterol and decreased triglyceride concentrations in subjects at high cardiovascular risk [30, 31]. In the context of the results of those intervention studies, our results support the hypothesis that a Mediterranean diet may not only have a beneficial effect on HDLcholesterol and triglyceride concentrations in high-risk populations but also in elderly subjects.

Out of the Mediterranean components, dairy consumption below the median of the study population was significantly associated with higher HDL-cholesterol concentration but not with lower triglyceride concentration. In contrast, observational studies found that a high calcium consumption was associated with higher HDLcholesterol concentration in women between 30 and 65 years [74] and in middle-aged and elderly women [75]. Furthermore, no association between dairy consumption and HDL-cholesterol was found in a Dutch elderly population [76]. These inconsistent findings may be caused by the lack of distinction between more healthy dairy products such as low-fat dairy products and less healthy dairy products such as high-fat dairy products. Because of the classification of foods according to the EUROCODE system we could not disentangle the effects of the types of diary products. It is therefore possible that in our study, subjects with a low dairy consumption were consuming more low-fat dairy products than the subjects with a high dairy consumption.

Our results showed that low meat and poultry consumption is associated with lower triglyceride concentration and they also suggest that low meat and poultry consumption is associated with higher HDL-cholesterol concentration. In a cross-sectional study in young adults, no association between meat consumption and HDL-cholesterol concentration was observed [77]. In another cross-sectional study in young adults, lower triglyceride concentration but similar HDL-cholesterol concentration was observed in subjects who consumed red meat and poultry less than once a week compared with subjects who consumed meat more frequently [78]. The latter study suggests the type of meat may also be important in studying the association between meat consumption and HDL-cholesterol and triglycerides. As we used the EUROCODE system as indicated earlier, we could not distinguish between types of meat.

Besides low consumption of dairy products or meat and poultry, other components 
of the MDS such as high MUFA/SFA ratio and high intake of legumes, nuts and seeds tended to be associated with higher HDL-cholesterol concentrations. Although these associations were not statistically significant, they are in line with the finding of other studies that found favourable effects of these components on serum lipid profiles [7981]. These findings suggest that these components are important contributors to the Mediterranean diet.

Our results also suggest that elderly subjects with good adherence to a Mediterranean diet have smaller waist circumference than subjects with poor adherence. Our results agree with the findings of two intervention studies that showed that consuming a Mediterranean diet substantially decreased waist circumference [30, 82]. Out of all Mediterranean components, low meat and poultry consumption was significantly associated with smaller waist circumference. These results are in line with findings from a cohort study in British adults [83] and a study combining data of the US Framingham Heart Study and the SENECA study [84].

Our study did not show an association between a Mediterranean diet with glucose and insulin concentrations or HOMA-IR, but elderly subjects with meat and poultry consumption below the median had significantly lower glucose concentrations. Our results are in line with the results of the Spanish cross-sectional study in younger subjects [29] that also found no association between a Mediterranean diet with insulin concentration and HOMA-IR. Intervention studies in subjects at high cardiovascular risk showed that a Mediterranean diet improved insulin sensitivity [30, 31]. However, an intervention study in a healthy study population did not show an effect of a Mediterranean diet on insulin sensitivity [32]. Results of these intervention studies, in combination with results of cross-sectional studies so far, suggest that a Mediterranean diet may be more effective to improve insulin sensitivity in persons with a high-risk profile than in healthy persons. However, the results of the Greek Attica study seem to contradict this hypothesis. In the Attica study adherence to a Mediterranean diet was associated with insulin and HOMA-IR in healthier subjects with a normal glucose tolerance but not in subjects with an impaired glucose tolerance or diabetes mellitus and therefore at higher risk for cardiovascular diseases [33].

Although no associations were found with the original MDS, insulin concentrations and HOMA-IR tended to be lower in subjects who adhered to the alternative MDS, which did not include alcohol consumption as component [69]. These associations were adjusted for alcohol intake and were not significant. As our study is the first to report the relation between a Mediterranean diet and insulin sensitivity in an elderly population and the results of studies in other age groups are inconsistent, we cannot exclude the possibility that a Mediterranean diet is related to insulin sensitivity in elderly populations.

An advantage of the SENECA study was the participation of study centres in both Mediterranean and non-Mediterranean countries that resulted in a large diversity in adherence to a Mediterranean diet. However, in multi-centre studies, nutritional and lifestyle factors are influenced by cultural differences between research centres. Consequently, we carried out our analysis with study centre in our model. Adjustment for study centre is likely to result in an overcorrection of the true association between 
the MDS and characteristics of the metabolic syndrome, but with disregard of this confounder no adjustments are made for non-diet related differences across study centres.

A possible limitation of the study was that our data could have been influenced by selective participation. Healthy elderly were most willing to participate in the SENECA study [65] and this could have diluted the association between a Mediterranean diet and the characteristics of the metabolic syndrome. In addition, the data of the SENECA study were collected in 1988 and 1989, therefore the study population may not be representative for the present European elderly. However, we do not expect the association between a Mediterranean diet and the metabolic syndrome to be different nowadays. Other limitations are related to the assessment of the MDS and the metabolic syndrome. We had to use a modified version of the MDS in which nuts were considered together with legumes in stead of with fruits and potatoes were considered together with vegetables instead of with cereals. These modifications of the MDS limit the comparability of our study with the studies of others. For the blood pressure characteristic of the metabolic syndrome we had to rely on self-reported hypertension instead of measured blood pressure.

Our results showed that elderly subjects with good adherence to a Mediterranean diet had higher HDL-cholesterol and lower triglyceride concentrations and tended to have smaller waist circumference than elderly subjects with poor adherence. It is therefore likely that good adherence to this diet is also associated with the metabolic syndrome in elderly populations.

\section{Acknowledgements}

The authors thank all principal investigators and collaborators of the SENECA's baseline study. Funding of the Netherlands Heart foundation (2003B068) is gratefully acknowledged. 


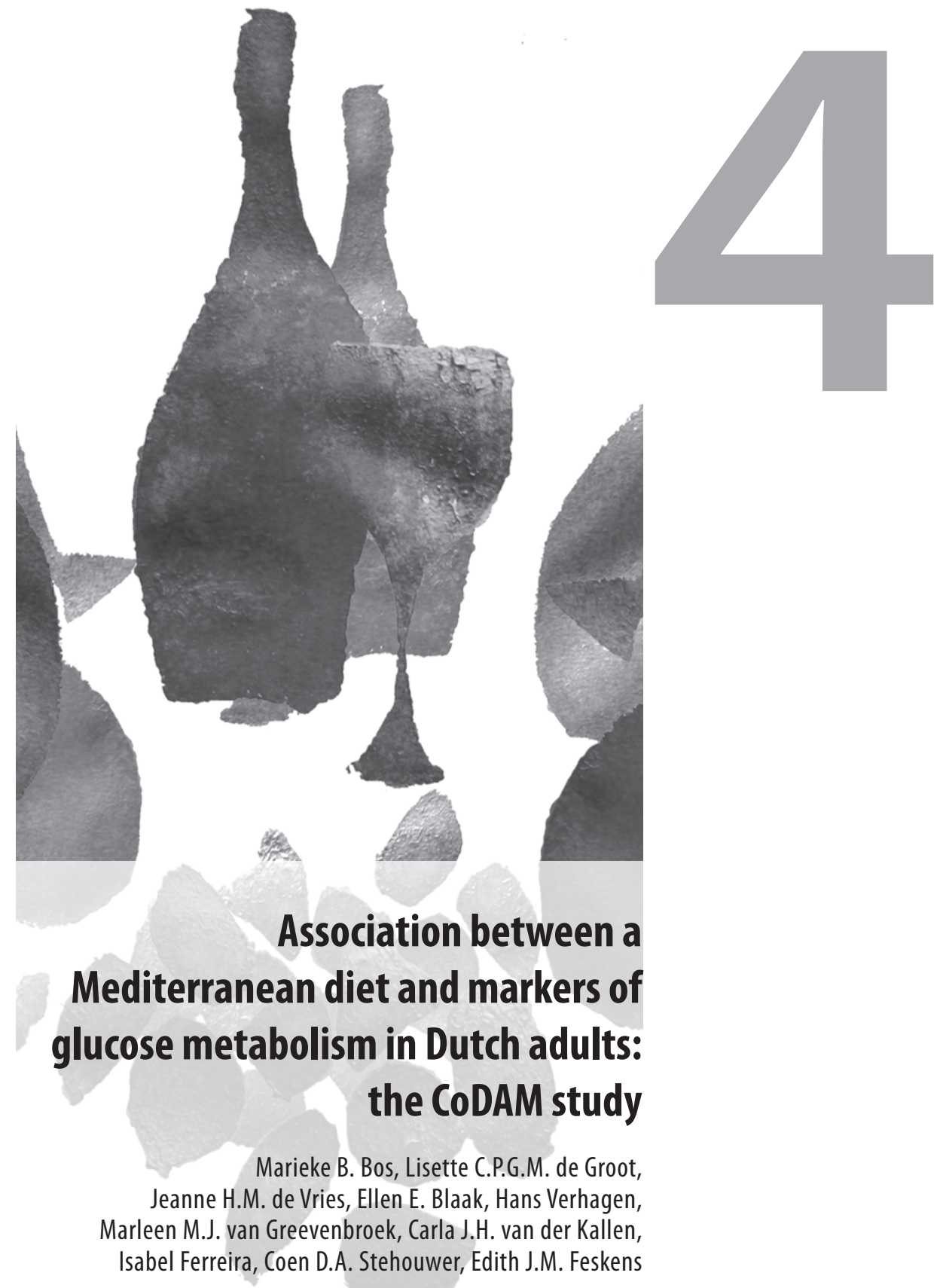




\begin{abstract}
Background and aims: Intervention studies have suggested that in subjects with highrisk of cardiovascular disease a Mediterranean diet is more effective to improve insulin sensitivity than in healthy subjects. However, one Greek observational study suggests the opposite. We investigated the cross-sectional association between a Mediterranean diet and markers of glucose metabolism in Dutch healthy subjects with normal glucose tolerance and in high-risk subjects with impaired glucose regulation or with diabetes mellitus type 2 .
\end{abstract}

Methods and results: A Mediterranean diet was assessed by the Mediterranean diet score (MDS range 0 through 9). In subjects with normal glucose tolerance, a Mediterranean diet was not associated with insulin and glucose concentrations, homeostatic model assessment, or $\mathrm{HbA1c}$ levels. In subjects with diabetes mellitus type 2, glucose concentration was higher $(0.6 \mathrm{mmol} / \mathrm{L}, 95 \% \mathrm{CI} 0.0 ; 1.2)$ and $\mathrm{HbAlc}$ level tended to be higher $(0.3 \%, 95 \% \mathrm{CI}-0.2 ; 0.7)$ in subjects with good adherence to a Mediterranean diet (MDS $>4$ ), than in subjects with poor adherence (MDS $\leq 4)$. No associations were found in subjects with impaired glucose regulation. Analyses were adjusted for age, prescribed dietary treatment, physical activity level, current smoking, family history of diabetes mellitus type 2, and use of antihypertensive or cholesterol lowering medication.

Conclusion: In our data we did not find support for a differential beneficial effect of a Mediterranean diet on insulin sensitivity in healthy subjects versus high-risk subjects.

\title{
Introduction
}

Reduced insulin sensitivity is a risk factor for diabetes mellitus type 2 and cardiovascular disease [85]. Interest has focused on the potential of a Mediterranean diet as protective against reduced insulin sensitivity $[36,86]$. This Mediterranean diet refers to a dietary pattern as consumed in countries of the Mediterranean region during the early $1960 \mathrm{~s}$, and is characterised by abundant use of plant foods (fruits, vegetables, cereals, legumes, nuts, and seeds) and olive oil, moderate intake of fish and wine, and low to moderate consumption of dairy products and meat and poultry [24-26]. A Mediterranean diet improved insulin sensitivity in intervention studies among subjects with a high risk of cardiovascular disease [30, 31], but not among subjects without a high risk [32]. These results suggest that a Mediterranean diet may be more effective to improve insulin sensitivity in high-risk subjects than in healthy subjects. However, one Greek observational study showed an association between a Mediterranean diet and insulin sensitivity in healthy subjects with normal glucose tolerance but not in high-risk subjects with impaired glucose regulation or with diabetes mellitus type 2 [33]. These findings contradict the results of the intervention studies, therefore they need to be confirmed. The Cohort study on Diabetes and Atherosclerosis Maastricht (CoDAM) in the Netherlands included healthy subjects with normal glucose tolerance and a high number of high-risk subjects with impaired glucose regulation or with diabetes mellitus type 2. We investigated the association between a Mediterranean diet and markers of glucose metabolism in healthy subjects and in high-risk subjects of the CoDAM study. As reduced insulin sensitivity is suggested to be one of the underlying mechanisms of the metabolic syndrome [1], we also investigated the association between a Mediterranean diet and the metabolic syndrome. 


\section{Methods}

\section{Study population}

We used data of the CoDAM study (1999-2000). The subjects of the CoDAM study were recruited from a study that monitored health and disease in the general Dutch population $[50,51]$. Inclusion criteria for participation in the CoDAM study were Caucasian ethnicity, age between 40 and 70 years, and at least one of the criteria: BMI $>25 \mathrm{~kg} / \mathrm{m}^{2}$, positive family history of diabetes mellitus type 2, history of gestational diabetes, postprandial blood glucose $>6.0 \mathrm{mmol} / \mathrm{L}$, glucosuria, or use of antihypertensive medication or medication known to affect glucose metabolism. Each subject who agreed to participate and fulfilled the inclusion criteria underwent two glucose tolerance tests except for 66 subjects who were already diagnosed with diabetes mellitus. The first test assessed glucose tolerance status using capillary blood samples and the second test using venous blood plasma. Subjects were classified into three groups of glucose tolerance status according to criteria of the World Health Organization [4]: normal glucose tolerance, impaired glucose regulation or diabetes mellitus type 2 . In total, data from 574 subjects were available for analyses: 301 subjects with normal glucose tolerance, 127 subjects with impaired glucose regulation, 80 subjects with newly diagnosed diabetes mellitus type 2 and 66 subjects with 'known' diabetes mellitus type 2 . Each subject gave written informed consent and the medical ethics committee of Maastricht University approved the study protocol.

\section{Dietary assessment}

A self-administered semi-quantitative food-frequency questionnaire was used to estimate the average consumption of 178 food items during the past year. For 21 food items, portion size was assessed using colour photographs of 2-4 differentially sized portions. For other food items, portion size was assessed by household measures (slices, glasses, etc.). The questionnaire was developed to assess habitual dietary intake in the Dutch cohort of the European Prospective Investigation into Cancer and nutrition and is a good method to rank people according to energy, macronutrients and food groups intakes $[87,88]$. Intakes of energy and nutrients were calculated using the Dutch food-composition table (NEVO 2001). We excluded data of subjects who had a large inconsistency between the answers on questions about the frequency of a hot meal and frequency of meat and vegetable consumption $(n=49)$. Adherence to a Mediterranean diet was assessed by the Mediterranean Diet Score (MDS) [25]. In this score, a Mediterranean diet is characterised by 9 components: (1) High ratio of monounsaturated to saturated fatty acids (MUFA to SFA), high intakes of (2) cereals (including bread and potatoes), (3) legumes, (4) fruits and nuts, (5) vegetables, and (6) fish, low intakes of (7) dairy products, (8) meat and poultry and (9) alcohol consumption between 10 through $50 \mathrm{~g} /$ day for men and between 5 through $25 \mathrm{~g} /$ day for women. For each protective component (1 through 6), a value of 1 was assigned to each subject whose intake was more than the energy-adjusted median. For each non-protective component $[7,8]$, a value of 1 was assigned to each subject whose intake was less than the energy-adjusted median. For alcohol intake [9], a value of 1 was also assigned to each subject whose intake was within the range (Table 4.1). The 
Table 4.1 Sex-specific cut-off values (based on medians of the population) and scoring for components of the Mediterranean diet score

\begin{tabular}{|c|c|c|c|c|}
\hline \multirow[t]{2}{*}{$\begin{array}{l}\text { Components of the Mediterranean } \\
\text { diet score }\end{array}$} & \multicolumn{3}{|c|}{$\begin{array}{l}\text { Energy adjusted }{ }^{1} \\
\text { sex specific cut-off values }\end{array}$} & \multirow[t]{2}{*}{ Scoring } \\
\hline & Male & Female & & \\
\hline MUFA/SFA & 0.84 & 0.81 & $>$ median & 1 (else 0) \\
\hline Cereals, g/day & 419 & 314 & $>$ median & 1 (else 0) \\
\hline Legumes, g/day & 6 & 4 & $>$ median & 1 (else 0) \\
\hline Fruits and nuts, g/day & 195 & 226 & $>$ median & 1 (else 0) \\
\hline Vegetables, g/day & 138 & 162 & $>$ median & 1 (else 0) \\
\hline Fish, g/day & 10 & 11 & $>$ median & 1 (else 0) \\
\hline Dairy products, g/day & 248 & 284 & $<$ median & 1 (else 0) \\
\hline Meat and poultry, g/day & 149 & 99 & $<$ median & 1 (else 0) \\
\hline Alcohol, g/day & $10-50$ & $5-25$ & Within range & 1 (else 0) \\
\hline
\end{tabular}

Abbreviation: monounsaturated/saturated fatty acids (MUFA/SFA).

${ }^{1}$ After adjustment for energy consumed (10.5 MJ for men and 8.4 MJ for women).

intakes were adjusted for energy intake (10.5 MJ for men and 8.4 MJ for women), therefore the medians are independent of variations in energy intake. Good adherence to a Mediterranean diet was defined by MDS above its median (MDS $>4$ ) and poor adherence was defined by MDS lower or equal to its median (MDS $\leq 4)$.

\section{Laboratory measurements}

Blood samples were taken from the antecubital vein while the subject was in a fasting state. Plasma glucose concentration was measured by the hexokinase method (HKG6PD method, ABX Diagnosis, Montepellier, France) at the Department of Clinical Chemistry of the VU University Medical Centre, Amsterdam, the Netherlands. HbA1c level was measured by using ion-exchange high performance liquid chromatography at the Department of Clinical Chemistry of the University Hospital Maastricht, Maastricht, the Netherlands. Plasma insulin concentration was measured by a two-sided immunoradiometric test using paired monoclonal antibodies (Medgenix Diagnostics, Fleurus, Belgium) at the Endocrinological Laboratory of the VU University Medical Centre. Homeostasis model assessment (HOMA) was used to assess insulin resistance (HOMA-IR) and $\beta$-cell function (HOMA-B) from glucose and insulin concentrations (http://www.dtu.ox.ac.uk/). HDL-cholesterol and triglyceride concentrations were determined using enzymatic methods (Roche Mannheim, Germany) at the Department of Clinical Chemistry of VU University Medical Centre.

\section{Other measurements}

Height and body weight were measured with subjects wearing light indoor clothing and no shoes. Waist circumference was measured midway between the lateral lower rib margin and the spina iliaca anterior superior. Blood pressure was measured twice on the right arm with the subject in supine position after 5 minutes of rest using a 
precision aneroid sphygmomanometer (Speidel \& Kelly Maxi Stabil 3, Jungingen, Germany). Systolic blood pressure (SBP) was defined according to Korotkoff sound I and diastolic blood pressure (DBP) according to Korotkoff sound V. The mean of the two measurements was used in the analyses. The Short Questionnaire to Assess Health-enhancing physical activity (SQUASH) was used to rank subjects according to their level of physical activity [89]. Each subject filled in a questionnaire about medical status, medicine use, and risk factors of cardiovascular disease such as smoking and family history of diabetes mellitus type 2 .

\section{Metabolic syndrome assessment}

The metabolic syndrome was diagnosed using the National Cholesterol Education Program (NCEP) criteria (2001), which were modified in 2005 [10]. According to these criteria, a subject is diagnosed with the metabolic syndrome when at least three of five characteristics are present: abdominal obesity (waist circumference $>102 \mathrm{~cm}$ for men and $>88 \mathrm{~cm}$ for women), hypertriglyceridaemia (triglyceride concentration $\geq 1.7$ mmol), low HDL-cholesterol concentration (HDL-cholesterol concentration $<1.04$ $\mathrm{mmol} / \mathrm{L}$ for men and $<1.29 \mathrm{mmol} / \mathrm{L}$ for women), hypertension (SBP $\geq 130 \mathrm{mmHg}$ and/ or DBP $\geq 85 \mathrm{mmHg}$ or use of anti-hypertensive medication), hyperglycaemia (glucose concentration $\geq 5.6 \mathrm{mmol} / \mathrm{L}$ or drug treatment for elevated glucose levels). Fibrates and nicotinic acid are the most commonly used drugs to treat hypertriglyceridaemia and low HDL-cholesterol concentration. Subjects taking one of these drugs were presumed to have hypertriglyceridaemia and low HDL-cholesterol concentration [10].

\section{Statistics}

After the exclusion of subjects with known diabetes mellitus $(n=66)$ or unreliable data on their food consumption or with missing data on markers of glucose metabolism, data of 450 subjects were used for statistical analyses. A linear-regression model was used to assess the association between a Mediterranean diet and markers of glucose metabolism. A Cox-regression model with robust error variance was used to estimate the prevalence ratio (PR) of the metabolic syndrome for subjects with good adherence to the Mediterranean diet compared with subjects with poor adherence [72]. We included an interaction term in the models to test whether the association between a Mediterranean diet and the outcome measures differed among subjects with normal glucose tolerance, impaired glucose regulation, or diabetes mellitus type 2 . All models were adjusted for potential confounding variables: age, prescribed dietary treatment, physical activity level, current smoking, family history of diabetes mellitus type 2 , and use of antihypertensive or lipid lowering medication (statins, fibrates or nicotinic acid). The Cox-regression models with metabolic syndrome as dependent variable were not adjusted for use of lipid-lowering or antihypertensive medication because medication use was included in the definition of the metabolic syndrome. Similarly, the Coxregression models with hypertriglyceridaemia or low HDL-cholesterol as dependent variable were not adjusted for use of lipid lowering medication and the model with hypertension as dependent variable was not adjusted for use of antihypertensive medication. The statistical SAS package, version 9.1 (SAS Institute Inc., Cary, NC, USA), was used to perform the analyses. 


\section{Results}

Out of 450 subjects, 275 subjects (61\%) had normal glucose tolerance, 111 subjects $(25 \%)$ had impaired glucose regulation, and 64 subjects (14\%) had diabetes mellitus type 2 . There were no differences among subjects with normal glucose tolerance, impaired glucose regulation, or diabetes mellitus type 2 in age, gender, current smoking, adherence to the Dutch physical activity guidelines or good adherence to a Mediterranean diet (Table 4.2). The metabolic syndrome and the characteristics of the metabolic syndrome were most prevalent in subjects with diabetes mellitus type 2 . The percentage of subjects that followed a prescribed dietary treatment was higher in subjects with diabetes mellitus type 2 or impaired glucose regulation compared with subjects with normal glucose tolerance.

Subjects with good adherence to a Mediterranean diet had higher MUFA/SFA ratio and higher intakes of cereals, legumes, fruits and nuts, and fish than subjects with poor

Table 4.2 Characteristics (mean (sd)) according to glucose tolerance status

\begin{tabular}{|c|c|c|c|}
\hline \multirow[t]{3}{*}{ Characteristics } & \multicolumn{3}{|c|}{ Glucose tolerance status } \\
\hline & $\begin{array}{c}\text { Normal glucose } \\
\text { tolerance }\end{array}$ & $\begin{array}{l}\text { Impaired glucose } \\
\text { regulation }\end{array}$ & $\begin{array}{c}\text { Diabetes mellitus } \\
\text { type } 2\end{array}$ \\
\hline & $\mathrm{N}=275$ & $N=111$ & $\mathrm{~N}=64$ \\
\hline Men, N (\%) & $163(59)$ & $66(59)$ & $45(70)$ \\
\hline Age, years & $58.5(7.3)$ & $59.6(6.7)$ & $59.6(6.5)$ \\
\hline Body mass index, $\mathrm{kg} / \mathrm{m}^{2}$ & $27.7(4.0)$ & $28.8(4.4)$ & $29.1(4.0)$ \\
\hline Insulin', pmol/L & $52.0(42.0,70.0)$ & $66.0(45.0,101.0)$ & $78.0(52.0,115.5)$ \\
\hline HOMA-IR ${ }^{1}$ & $1.0(0.8,1.3)$ & $1.3(0.9,1.9)$ & $1.5(1.0,2.3)$ \\
\hline HOMA-B & $91.8(25.5)$ & $86.8(33.8)$ & $67.7(32.4)$ \\
\hline Glucose, $\mathrm{mmol} / \mathrm{L}$ & $5.3(0.4)$ & $5.9(0.5)$ & $7.2(1.1)$ \\
\hline $\mathrm{HbA} 1 \mathrm{c}^{2}, \%$ & $5.6(0.4)$ & $5.8(0.4)$ & $6.4(0.7)$ \\
\hline Good adherence to a Mediterranean diet, N (\%) & $116(42)$ & $54(49)$ & $31(48)$ \\
\hline $\begin{array}{l}\text { Physical activity level (>30 min/day at moderate } \\
\text { intensity at least } 5 \text { days/week), } \mathrm{N}(\%)\end{array}$ & $179(65)$ & $64(58)$ & $40(63)$ \\
\hline Family history of DM, N (\%) & $99(36)$ & $56(50)$ & $31(48)$ \\
\hline Current smoking, N (\%) & $59(21)$ & $20(18)$ & $12(19)$ \\
\hline Following prescribed dietary treatment, $\mathrm{N}(\%)$ & $21(8)$ & $22(20)$ & $15(23)$ \\
\hline Metabolic syndrome, N (\%) & $90(33)$ & $75(68)$ & $54(84)$ \\
\hline Hypertriglyceridaemia, N (\%) & $70(25)$ & $52(47)$ & $38(59)$ \\
\hline Low HDL-cholesterol, N (\%) & $104(38)$ & $52(47)$ & $36(56)$ \\
\hline Abdominal obesity, N (\%) & $130(47)$ & $66(59)$ & $43(67)$ \\
\hline Hyperglycaemia, N (\%) & $55(20)$ & $82(74)$ & $60(94)$ \\
\hline Hypertension, N (\%) & $190(69)$ & $97(87)$ & $62(97)$ \\
\hline
\end{tabular}

Abbreviations: homeostasis model assessment insulin resistance (HOMA-IR), homeostasis model assessment $\beta$-cell function (HOMA-B), glycated haemoglobin (HbA1c), diabetes mellitus (DM).

${ }^{1}$ Median (interquartile range).

${ }^{2}$ Normal glucose tolerance, $\mathrm{N}=266$; impaired glucose tolerance, $\mathrm{N}=107$; diabetes mellitus type 2, $\mathrm{N}=63$

Metabolic syndrome was defined according to the NCEP criteria [10]. 
adherence to Mediterranean diet (Table 4.3). Mean intakes of dairy products, meat and poultry and alcohol were not significantly different between subjects with good adherence to a Mediterranean diet and subjects with poor adherence.

In subjects with normal glucose tolerance, a Mediterranean diet was not associated with insulin or glucose concentration, HbAlc levels, or HOMA scores (Table 4.4). In subjects with impaired glucose regulation or diabetes mellitus type 2, a Mediterranean diet was not associated with insulin concentration or HOMA scores. However, in subjects with diabetes mellitus type 2 glucose concentration was higher $(0.6 \mathrm{mmol} / \mathrm{L}$, $95 \% \mathrm{CI} 0.0 ; 1.2)$ and $\mathrm{HbA} 1 \mathrm{c}$ level tended to be higher $(0.3 \%, 95 \% \mathrm{CI}-0.2 ; 0.7)$ in subjects with good adherence to a Mediterranean diet, than in subjects with poor adherence. No associations between a Mediterranean diet and glucose or HbAlc were found in subjects with impaired glucose regulation.

In the total population, a Mediterranean diet was not associated with the metabolic syndrome (PR 1.0, 95\%CI 0.8; 1.2). In addition, a Mediterranean diet was not associated with hypertriglyceridaemia (PR 1.1, 95\%CI 0.9; 1.5), low HDL-cholesterol (PR 1.2, 95\% CI $0.9 ; 1.4$ ), hyperglycaemia (PR 1.1, 95\%CI $0.9 ; 1.2$ ) or hypertension (PR 0.9, $95 \%$ CI $0.9 ; 1.1$ ). These associations were not different among subjects with normal glucose tolerance, impaired glucose regulation or diabetes mellitus type 2 . Subjects with normal glucose tolerance with good adherence to a Mediterranean diet had less abdominal obesity than subjects with poor adherence (PR 0.7, 95\%CI 0.6; 1.0). However, subjects with diabetes mellitus type 2 with good adherence to a Mediterranean diet tended to have more abdominal obesity than subjects with poor adherence (PR $1.3,95 \%$ CI $0.9 ; 1.8)$. No association between a Mediterranean diet and abdominal obesity was found in subjects with impaired glucose regulation.

Table 4.3 Mean energy adjusted intakes ${ }^{1}(\mathrm{sd})$ of Mediterranean components of subjects with poor and good adherence to a Mediterranean diet

\begin{tabular}{llll}
\hline \multirow{2}{*}{$\begin{array}{l}\text { Components of the } \\
\text { Mediterranean diet score }\end{array}$} & Poor adherence (MDS $\leq 4)$ & Good adherence (MDS >4) & p-value \\
\hline N & Mean (sd) & Mean (sd) & \\
MUFA/SFA & 249 & 201 & $<0.001$ \\
Cereals, g/day & $0.82(0.13)$ & $0.88(0.12)$ & $<0.001$ \\
Legumes, g/day & $361(109)$ & $416(121)$ & $<0.001$ \\
Fruits and nuts, g/day & $6(10)$ & $11(10)$ & $<0.001$ \\
Vegetables, g/day & $202(129)$ & $264(145)$ & $<0.001$ \\
Fish, g/day & $136(58)$ & $182(69)$ & $<0.001$ \\
Dairy products, g/day & $10(12)$ & $18(20)$ & 0.14 \\
Meat and poultry, g/day & $327(230)$ & $294(242)$ & 0.20 \\
Alcohol, g/day & $135(57)$ & $128(61)$ & 0.07 \\
\hline
\end{tabular}

Abbreviations: Mediterranean diet score (MDS), monounsaturated/saturated fatty acids (MUFA/SFA).

${ }^{1}$ After adjustment for energy consumed (10.5 MJ for men and 8.4 MJ for women). 
Table 4.4 Differences in markers of glucose metabolism between subjects with good adherence to a Mediterranean diet and subjects with poor adherence among subjects with normal glucose tolerance, impaired glucose tolerance or diabetes mellitus type 2

\begin{tabular}{|c|c|c|c|c|c|c|c|}
\hline \multirow{3}{*}{$\begin{array}{l}\text { Markers of glucose } \\
\text { metabolism }\end{array}$} & \multicolumn{6}{|c|}{ Glucose tolerance status } & \multirow{3}{*}{$\begin{array}{r}\text { Interaction } \\
\text { IGR/DM2 } \\
\text { p-values }\end{array}$} \\
\hline & \multicolumn{2}{|c|}{$\begin{array}{c}\text { Normal glucose } \\
\text { tolerance } \\
\mathrm{N}=275\end{array}$} & \multicolumn{2}{|c|}{$\begin{array}{l}\text { Impaired glucose } \\
\text { regulation } \\
N=111\end{array}$} & \multicolumn{2}{|c|}{$\begin{array}{c}\text { Diabetes mellitus } \\
\text { type } 2 \\
N=64\end{array}$} & \\
\hline & estimate & $95 \% \mathrm{Cl}$ & estimate & $95 \% \mathrm{Cl}$ & estimate & $95 \% \mathrm{Cl}$ & \\
\hline \multicolumn{8}{|c|}{ Plasma insulin, pmol/L } \\
\hline Crude model & 1.6 & $-5.2 ; 8.4$ & 7.9 & $-9.3 ; 25.2$ & 0.6 & $-23.7 ; 22.41$ & $0.44 / 0.82$ \\
\hline Full model & 0.5 & $-6.4 ; 7.4$ & 8.8 & $-9.5 ; 27.0$ & -1.5 & $-26.0 ; 23.0$ & $0.37 / 0.86$ \\
\hline \multicolumn{8}{|l|}{ HOMA-IR } \\
\hline Crude model & 0.0 & $-0.1 ; 0.2$ & 0.2 & $-0.2 ; 0.5$ & 0.0 & $-0.4 ; 0.5$ & $0.44 / 0.94$ \\
\hline Full model & 0.0 & $-0.1 ; 0.1$ & 0.2 & $-0.2 ; 0.5$ & 0.0 & $-0.5 ; 0.5$ & $0.37 / 0.98$ \\
\hline \multicolumn{8}{|l|}{ HOMA-B } \\
\hline Crude model & 0.4 & $-6.0 ; 6.8$ & 1.5 & $-11.2 ; 14.3$ & -9.5 & $-25.7 ; 6.7$ & $0.87 / 0.23$ \\
\hline Full model & 0.9 & $-5.7 ; 7.5$ & 4.4 & $-8.8 ; 17.6$ & -11.5 & $-29.1 ; 6.1$ & $0.75 / 0.25$ \\
\hline \multicolumn{8}{|c|}{ Plasma glucose, $\mathrm{mmol} / \mathrm{L}$} \\
\hline Crude model & 0.0 & $-0.1 ; 0.1$ & 0.1 & $-0.1 ; 0.3$ & 0.5 & $0.0 ; 1.0$ & $0.62 / 0.002$ \\
\hline Full model & 0.0 & $-0.1 ; 0.1$ & 0.1 & $-0.1 ; 0.3$ & 0.6 & $0.0 ; 1.2$ & $0.74 / 0.002$ \\
\hline \multicolumn{8}{|l|}{$\mathrm{HbA} 1 \mathrm{c}^{1}, \%$} \\
\hline Crude model & 0.0 & $-0.1 ; 0.1$ & 0.0 & $-0.2 ; 0.1$ & 0.2 & $-0.2 ; 0.6$ & $0.61 / 0.19$ \\
\hline Full model & 0.0 & $-0.1 ; 0.1$ & -0.1 & $-0.2 ; 0.1$ & 0.3 & $-0.2 ; 0.7$ & $0.77 / 0.11$ \\
\hline
\end{tabular}

Abreviations: impaired glucose regulation (IGR), diabetes mellitus type 2 (DM2), homeostasis model assessment insulin resistance (HOMA-IR), homeostasis model assessment $\beta$-cell function (HOMA-B), glycated haemoglobin (HbA1c).

Full models are adjusted for age, prescribed dietary treatment, physical activity level, current smoking, family history of diabetes mellitus, use of antihypertensive or lipid lowering medication.

${ }^{1}$ Normal glucose tolerance, $\mathrm{N}=266$; impaired glucose tolerance, $\mathrm{N}=107$; diabetes mellitus type 2, $\mathrm{N}=63$.

\section{Discussion}

No beneficial associations between a Mediterranean diet and markers of glucose metabolism were found. Therefore, the present paper does not provide support for a differential beneficial effect of a Mediterranean diet in healthy versus high-risk subjects.

By recruiting high-risk subjects from a monitoring study, we managed to include a large number of high-risk subjects in our study. Our study had a cross-sectional design, therefore we cannot preclude the possibility that predominantly subjects with impaired glucose regulation or diabetes mellitus type 2 might have adopted a healthier diet prior to our study. Although subjects were unaware of their glucose tolerance status when they reported their dietary pattern, other conditions closely related to impaired glucose regulation such as abdominal obesity, hypertension or dyslipidaemia may have influenced dietary patterns. This influence is suggested by the higher percentage of 
subjects that followed a prescribed diet in high-risk subjects (21\%) compared with healthy subjects $(8 \%)$.

Our results, which suggest an adverse effect of a Mediterranean diet in subjects with diabetes mellitus type 2 , may be due to the high number of subjects with abdominal obesity in this group (67\%) compared with subjects with impaired glucose regulation $(59 \%)$ or healthy subjects $(47 \%)$. It has been suggested that subjects with obesity underreport energy intake [90] and report more healthy dietary habits than those they actually have consumed. Despite the validated methodology for assessing dietary intakes, the high number of subjects with abdominal obesity along with the low number of subjects with diabetes mellitus type 2 might explain the unexpected positive association between a Mediterranean diet and glucose concentrations.

Our study does not confirm the findings of the study by Panagiotakos et al. [33], the only (cross-sectional) study that also compared healthy subjects with high-risk subjects, and that did find an association between a Mediterranean diet and markers of glucose metabolism in healthy subjects. In the study by Panagiotakos et al., good adherence to a Mediterranean diet was assessed by a Mediterranean diet score (range 0-55). In our study, we applied the Mediterranean diet score that was developed by Trichopoulou et al. [25]. This Mediterranean diet score has been associated with mortality in Northern Europe [91], therefore, we a priori assumed sufficient betweensubject variation in intake of Mediterranean food components in our study. Such variation is needed for detecting an association between a Mediterranean diet and markers of glucose metabolism. In actual comparisons of our intakes with the intakes in the Northern European study we found similar variation in intake of Mediterranean food components.

Although the variability in intakes of Mediterranean components seemed sufficient, the diet of subjects with good adherence to a Mediterranean diet does not necessarily resemble the diet that was consumed in countries of the Mediterranean region during the early 1960s. In 1960, men living in Crete (Greece) who participated in the Seven Countries Study had on average higher intakes of legumes ( $26 \mathrm{~g} /$ day), fruits (410 g/ day), vegetables (169 g/day), and fish ( $16 \mathrm{~g} /$ day) and lower intakes of dairy products $(219 \mathrm{~g} /$ day $)$ and meat and poultry ( $44 \mathrm{~g} /$ day) than men in our study [92]. In addition, a MUFA/SFA ratio of at least above 1 is expected in a traditional Mediterranean diet that contains abundant olive oil, whereas in our study the median MUFA/SFA ratio was around 0.8 . Therefore, the contrast between good and poor adherence to a Mediterranean diet in our study might be smaller compared with studies performed in the Mediterranean region. The smaller contrast in our study might explain why we were not able to confirm the results of the study by Panagiotakos et al. [33]. Contrary to the findings of intervention studies, our findings do not underpin the observed beneficial effects of providing a Mediterranean diet to high-risk subjects [30, 31]. This might be due to stronger dietary contrasts that were introduced in intervention studies.

The association between a Mediterranean diet and the metabolic syndrome has been studied before in three observational studies from the South of Europe. Two of these studies found that a Mediterranean diet was associated with a lower prevalence of the metabolic syndrome in Greece [27] or a lower incidence of the metabolic syndrome 
in Spain [28] and one Spanish study found no association [29], which was in line with the present study.

In our study that included both healthy and high-risk subjects from a Northern European population, we did not find support for the hypothesis that a Mediterranean diet would be more effective to improve markers of glucose metabolism in high-risk subjects than in healthy subjects.

\section{Acknowledgements}

The CoDAM study was supported by a grant from the Netherlands Organization for Scientific Research (940-35-034) and the Dutch Diabetes Foundation (98.901).

The research activities of $\mathrm{M}$ Bos are supported by a grant from the Netherlands Heart Foundation (grant 2003B068). Dr I Ferreira's research activities are supported by a post-doc research grant from the Netherlands Heart Foundation (grant 2006T050). 

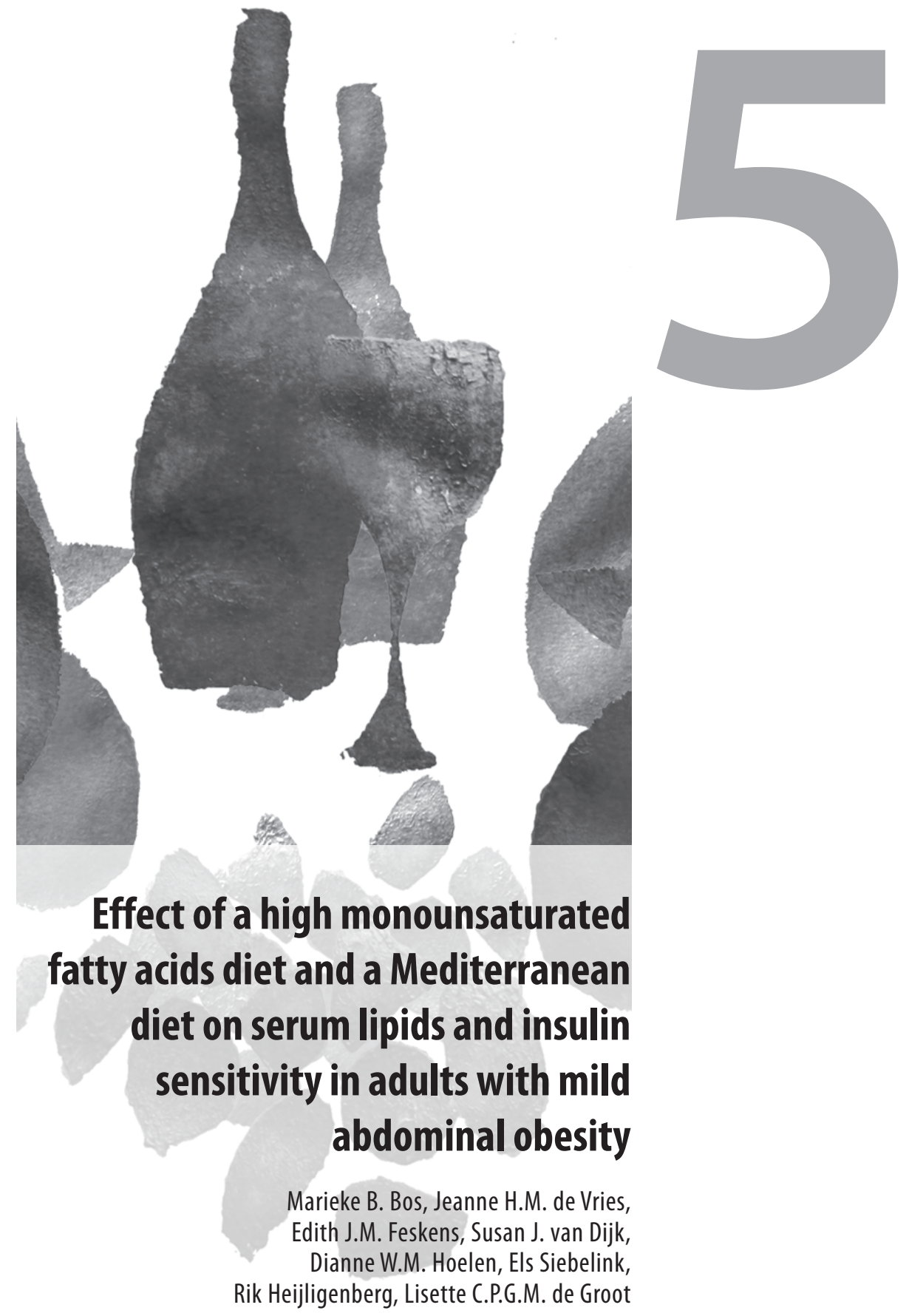


\section{Abstract}

Background and aims: Diets high in monounsaturated fatty acids (MUFA) such as a Mediterranean diet may reduce the risk of cardiovascular diseases by improving insulin sensitivity and serum lipids. Besides being high in MUFA, a Mediterranean diet also contains abundant plant foods, moderate wine and fish, and low amounts of meat and dairy products, which may also play a role. We compared the effects of a high MUFA-diet with a diet high in saturated fatty acids (SFA) and the additional effect of a Mediterranean diet on insulin sensitivity and serum lipids.

Methods and results: A randomized parallel controlled-feeding trial was performed in 60 non-diabetics (40-65 years) with mild abdominal obesity. After a two week run-in diet high in SFA (19\% of total energy intake (energy-\%)), subjects were allocated to a high MUFA-diet (20 energy-\%), a Mediterranean diet (MUFA 21 energy-\%), or the high SFAdiet, for eight weeks. The high MUFA and the Mediterranean diet did not affect fasting insulin concentrations. The high MUFA-diet reduced total cholesterol $(-0.41 \mathrm{mmol} / \mathrm{L}$, $95 \% \mathrm{CI}-0.74 ;-0.09)$ and LDL-cholesterol $(-0.38 \mathrm{mmol} / \mathrm{L}, 95 \% \mathrm{CI}-0.65 ;-0.11)$ compared with the high SFA-diet, but not triglyceride concentrations. The Mediterranean diet increased HDL-cholesterol concentrations $(+0.09 \mathrm{mmol} / \mathrm{L}, 95 \% \mathrm{CI} 0.0 ; 0.18)$ and reduced the ratio of total cholesterol/HDL-cholesterol $(-0.39,95 \% \mathrm{CI}-0.62 ;-0.16)$ compared with the high MUFA-diet.

Conclusion: Replacing a high SFA-diet with a high MUFA or a Mediterranean diet did not affect insulin sensitivity, but improved serum lipids. The Mediterranean diet was most effective, it reduced total and LDL-cholesterol, and also increased HDL-cholesterol and reduced total cholesterol/HDL-cholesterol ratio.

\section{Introduction}

Dietary fatty acids affect metabolic risk profiles for diabetes mellitus and cardiovascular disease $[34,93]$. Replacing saturated fatty acids (SFA) with monounsaturated fatty acids (MUFA) reduces total cholesterol, LDL-cholesterol, and triglyceride concentrations [39]. Replacing SFA with MUFA may also improve insulin sensitivity as observational studies showed that diets high in SFA are associated with reduced insulin sensitivity [34, 94], and intervention studies showed that insulin sensitivity increased after replacing SFA with MUFA [40, 41].

Olive oil is rich in MUFA, and is the main source of fat in a Mediterranean diet [24]. A Mediterranean diet is characterised by abundant use of plant foods (fruits, vegetables, cereals, legumes, nuts, and seeds), moderate intake of fish and wine, and low to moderate consumption of dairy products, meat and poultry [24-26]. Some of these components, such as nuts, fish, dietary fibre, and alcohol may also favourably affect serum lipids or insulin sensitivity [35-38, 95]. Thus, the cumulative effect of the multiple Mediterranean components on serum lipids and insulin sensitivity may be larger than the effect of a high MUFA-diet alone.

Intervention studies showed that a Mediterranean diet reduced total cholesterol and insulin concentrations more than a diet lower in MUFA [30, 31]. However, they were unable to determine whether the effects of the Mediterranean diet were due to the high MUFA content of the diet or to the cumulative effect of the Mediterranean diet components. We studied whether replacing a high SFA-diet with a high MUFA-diet improved serum lipids and insulin sensitivity. In addition, we examined whether a Mediterranean diet with a high MUFA content and other Mediterranean components 
improved serum lipids and insulin sensitivity more than a high MUFA-diet. We conducted a parallel controlled-feeding trial, in which we controlled energy intake and macronutrient composition of the intervention diets.

\section{Methods}

\section{Study population}

Subjects were recruited from Wageningen and surroundings. Men and women who did not use antihypertensive or cholesterol-lowering medication, and without diabetes mellitus were invited for a screening visit. We included subjects aged 40-65 years with a $\mathrm{BMI} \geq 25 \mathrm{~kg} / \mathrm{m}^{2}$ or a waist circumference $\geq 94 \mathrm{~cm}$ for men and $\geq 80 \mathrm{~cm}$ for women to have a study population with a higher chance of reduced insulin sensitivity. We excluded subjects with fasting total cholesterol $\geq 8 \mathrm{mmol} / \mathrm{L}$, subjects who consumed more than 4 glasses of alcohol/day, subjects who participated in other dietary or drugs trials $<4$ weeks before the start of the study, and pregnant or lactating women. We performed an oral glucose-tolerance test to exclude non-treated diabetics [4]. We used questionnaires to collect information about general characteristics and medical status. All 60 eligible subjects were asked to undergo a hyperinsulinemic-euglycemic clamp to measure insulin sensitivity and 30 subjects agreed to participate. All subjects signed informed consent.

\section{Study design}

The study was conducted from January to April 2007 at Wageningen University. The medical ethical committee of Wageningen University approved the study. All 60 subjects received a Western-style diet high in SFA (19\% of total energy intake (energy-\%)) for a two weeks run-in period to standardize dietary conditions among groups. After these two weeks, a staff member who was not involved in the study blindly allocated the subjects to one of the three intervention diets: a high SFA-diet, a high MUFA-diet, or a Mediterranean diet. This was done by randomization with stratification for gender and agreement to participate in the additional clamp studies. Couples were allocated to the same intervention diet.

The high SFA-diet had the same composition as the run-in diet. The high MUFA-diet was rich in refined olive oil and contained a higher percentage of energy from MUFA and a lower percentage of SFA than the high SFA-diet (Table 5.1). The high MUFA-diet had similar contents of carbohydrates, protein, and dietary fibre as the high SFA-diet. The Mediterranean diet was rich in extra-virgin olive oil and had similar contents of MUFA and SFA, higher intakes of vegetables and fruits and lower intakes of dairy products and meat than the high MUFA-diet. Subjects consumed the intervention diets for eight weeks.

Before the start of the study the habitual energy intake of individual subjects was estimated by a food-frequency questionnaire [96]. Subjects received foods covering $90 \%$ of their energy needs. Each subject was obliged to choose additional foods for the remaining $10 \%$ of energy needs from a so called free-choice list containing food items low in fat and dietary fibre. The diets were provided as a 14 day menu cycle. Subjects 
Table 5.1 Mean daily intake of energy and nutrients of subjects on the high SFA, high MUFA, or Mediterranean diets

\begin{tabular}{lccc}
\hline & High SFA & High MUFA & Mediterranean \\
\hline Energy, MJ/day & 10.7 & 10.4 & 10.3 \\
Total fat, energy-\% & 36.8 & 39.9 & 40.2 \\
$\quad 19.2$ & 10.9 & 10.7 \\
$\quad$ MFA & 10.7 & 20.3 & 21.4 \\
$\quad$ PUFA & 5.4 & 7.0 & 6.5 \\
$\quad 0.4$ & 0.6 & 0.8 \\
$\quad$ n-3 PUFA & 5.0 & 6.4 & 5.6 \\
n-6 PUFA & 13.5 & 11.4 & 14.5 \\
Carotein, energy-\% & 47.3 & 46.4 & 41.1 \\
Dietary fibre, g/MJ & 2.4 & 2.4 & 3.6 \\
Cholesterol, mg/MJ & 25.7 & 24.2 & 25.6 \\
Alcohol', energy-\% & 2.3 & 2.2 & 4.2 \\
\hline
\end{tabular}

Abbreviations: Saturated fatty acids (SFA), monounsaturated fatty acids (MUFA), polyunsaturated fatty acids (PUFA), percentage of total energy intake (energy-\%)

Values are based on chemical analysis of complete duplicate diets plus the calculated contribution of freechoice items. The duplicate diets were collected daily and pooled for each intervention group.

${ }^{1}$ Red wine was provided in the Mediterranean diet group. Alcohol consumption (maximum 2 glasses/day) was allowed in the other diets as well, with the exception of red wine.

consumed their hot meal on workdays at Wageningen University under supervision of the researchers. Breakfast, bread meals, snacks, beverages, and all meals for the weekends were provided in take-home packages. Subjects were carefully instructed how to prepare the take-home meals.

Some foods were exclusively provided in the Mediterranean diet: fatty fish (3 servings/ week), unrefined-grain products, nuts (15 g/day), legumes (40 g/day), and red wine (1 glass/day). Alcohol was not provided in the high MUFA and SFA-diet but subjects were allowed to drink alcohol as free-choice items except for red wine or red-port wine. Maximum alcohol consumption in all groups was 2 glasses/day. Subjects were asked to maintain their usual pattern of physical activity, smoking habits, and use of oral contraceptives throughout the study. They recorded any signs of illness, used medications, food items chosen from the free-choice list, and deviations from dietary guidelines in diaries.

Body weight was measured twice a week and energy intake was adjusted in case of weight change. When subjects had incidental increased energy requirements, e.g. because of sports, a bread bun (500 kJ/bun) was provided with the same relative macronutrient composition as the intervention diet of the subject. Duplicate portions of an average energy level of $11 \mathrm{MJ}$ of each intervention diet were collected daily, pooled by intervention group and analysed for energy, macronutrients, fatty acids, and dietary fibre composition after the study. The average energy and nutrient content of the reported free-choice items per intervention group was calculated using the Dutch 
food-composition table (NEVO, 2006). The values of the duplicate portions and the free-choice items were combined (Table 5.1).

An intervention study that compared the effects of a high MUFA-diet with a high SFA-diet observed a difference of $17.6 \mathrm{pmol} / \mathrm{L}$ in insulin concentration (personal communication with Perez-Jimenez) [40]. In our power calculations, we expected a differential change in fasting insulin concentration of $8.5 \mathrm{pmol} / \mathrm{L}$ and a standard deviation of the within-group difference of $9.0 \mathrm{pmol} / \mathrm{L}$. We expected a differential change in total cholesterol concentrations of $0.52 \mathrm{mmol} / \mathrm{L}$ and a standard deviation of the within-group difference of $0.47 \mathrm{mmol} / \mathrm{L}$ [97]. A sample size of $n=20$ per intervention group was required to detect differential changes in fasting insulin and total cholesterol concentrations, with a power of $80 \%$ at a significance level of 0.05 , taking into account a drop out of $10 \%$.

\section{Measurements}

Four blood samples were drawn, two at baseline (at the end of the run-in period; day 10 or 11 , and day 15 or 16) and two at the end of the study (day 65 or 66, and day 70 or 71). We took the mean of two measurements sampled at baseline and at the end of the study. Venous blood was taken from the antecubital vein after an overnight fast. All serum samples were kept at $-80 \mathrm{oC}$ until further analysis within one run. Concentrations of total- and HDL-cholesterol and triglycerides were measured by a Dimension Clinical Chemistry System (Dade Behring Inc, USA) by Stichting Huisartsenlaboratorium Oost, Velp, the Netherlands. LDL-cholesterol was calculated with the formula of Friedewald [98]. Concentrations of insulin and C-peptide were measured using an immunometric assay (Bayer diagnostics, Mijdrecht, the Netherlands) by the Laboratory of Endocrinology, VU University, Amsterdam, the Netherlands. Blood for glucose measurement was collected in $\mathrm{NaF}$ tubes. These tubes were stored for a maximum of $24 \mathrm{~h}$ at $2-8 \mathrm{oC}$, until plasma glucose was measured by Stichting Huisartsenlaboratorium Oost, Velp, the Netherlands, on the Synchron LX20 system using hexokinase and glucose-6-phosphate dehydrogenase (Glucose reagent, Beckman Coulter, Fullerton, USA). Homeostatic model assessment (HOMA-IR) was used for assessing insulin sensitivity from fasting glucose and insulin concentrations (http://www.dtu.ox.ac.uk/).

Anthropometric measurements were performed at baseline and at the end of the study by the same researcher. Body weight of subjects wearing indoor clothing without footwear was measured to the nearest $0.1 \mathrm{~kg}$ using a digital weighing scale (Seca, Bascule MT, USA). Waist circumference was measured in duplicate midway between the lower rib margin and the iliac crest, accurate to $0.5 \mathrm{~cm}$, using a non stretchable tape. Height was measured to the nearest $0.1 \mathrm{~cm}$ using a microtoise.

Thirty subjects underwent a hyperinsulinemic-euglycemic clamp to assess stimulated insulin sensitivity [99]. Clamp measurements were performed during the period from two weeks before until the first week of the run-in period and during the last three weeks of the intervention period in Hospital Gelderse Vallei, Ede, the Netherlands. Glucose was clamped at a glucose concentration of $5 \mathrm{mmol} / \mathrm{L}$ by titrating a variablerate glucose infusion (20\%) against a fixed-rate infusion of soluble insulin (Actrapid, 
$100 \mathrm{IU} / \mathrm{ml}$, at the rate of $40 \mathrm{mIU} / \mathrm{ml} / \mathrm{min} / \mathrm{m}^{2}$ ). The glucose infusion rate was computed based on measurements of glucose concentrations by a HemoCue blood analyser on five-minute intervals throughout the clamp. After reaching steady state for at least 30 minutes, the degree of insulin sensitivity (M-value) was determined as the amount of glucose necessary to maintain the blood glucose concentration divided by the fatfree mass (FFM). FFM was measured by air-displacement plethysmography in the Bod Pod [100].

\section{Statistics}

Differential changes between the high MUFA-diet and the high SFA-diet and between the Mediterranean diet and the high MUFA-diet were examined using analysis of covariance with predefined contrasts. Group differences in outcome measures measured after eight weeks of interventions were adjusted for each subjects baseline value of the outcome measure [101], gender and participation in clamp measurements [102]. We analysed the data using SAS 9.1.3 (SAS Institute Inc., Cary, NC, USA).

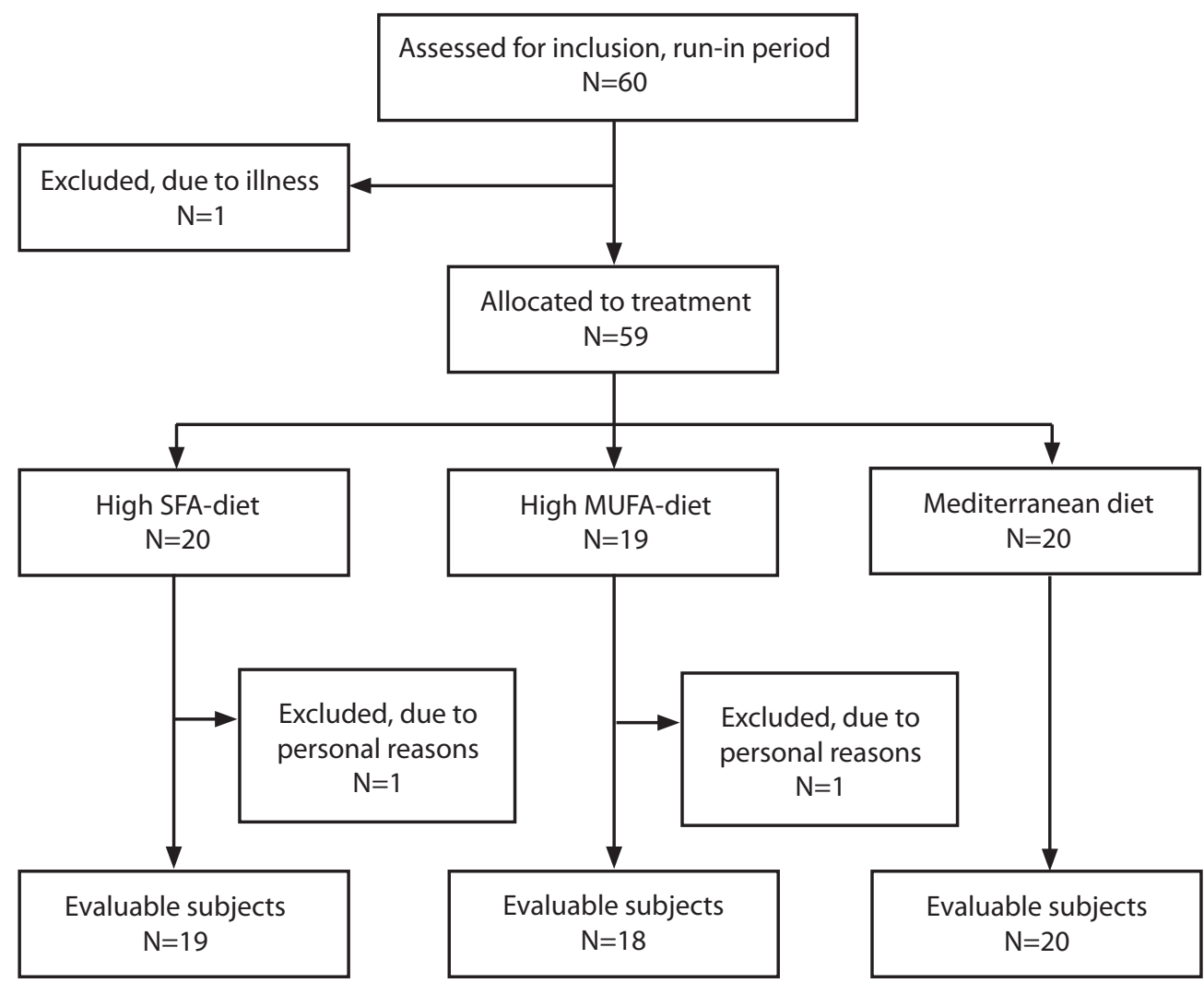

Figure 5.1 Flow diagram of the study. 


\section{Results}

Fifty-seven out of 60 subjects completed the trial (Figure 5.1). One subject withdrew during the run-in period because of illness and two subjects withdrew during the intervention period because of personal reasons. Subjects in the three intervention groups were comparable in their baseline concentrations of the outcome measures of the study (Table 5.2). Subjects reported no important deviations from the study protocol.

The high MUFA-diet reduced total and LDL-cholesterol concentrations and the total cholesterol/HDL-cholesterol ratio compared with the SFA-diet (Table 5.3). The Mediterranean diet did not reduce total and LDL-cholesterol but increased HDLcholesterol concentration and reduced the total cholesterol/HDL-cholesterol ratio compared with the high MUFA-diet. Changes in triglyceride concentration were not significantly different between the high MUFA-diet and the SFA-diet, but the Mediterranean diet tended to reduce triglycerides compared with the high MUFAdiet.

The change in insulin concentration was not significantly different between the high MUFA-diet and the high SFA- diet nor between the Mediterranean diet and the high MUFA-diet. Also no differential changes in C-peptide, HOMA-IR and glucose were

Table 5.2 Baseline characteristics of the 57 subjects completing the study

\begin{tabular}{|c|c|c|c|}
\hline & \multicolumn{3}{|c|}{ Mean (sd) } \\
\hline & $\begin{array}{l}\text { High SFA } \\
\mathrm{N}=19\end{array}$ & $\begin{array}{l}\text { High MUFA } \\
\qquad \mathrm{N}=18\end{array}$ & $\begin{array}{c}\text { Mediterranean } \\
\mathrm{N}=20\end{array}$ \\
\hline Age, years & $52.0(7.2)$ & $58.9(5.1)$ & $56.8(6.0)$ \\
\hline Men, N (\%) & $8(42)$ & $8(44)$ & $8(40)$ \\
\hline Body weight, kg & $79.9(12.9)$ & $79.2(14.0)$ & $84.0(14.6)$ \\
\hline Body mass index, $\mathrm{kg} / \mathrm{m}^{2}$ & $26.1(2.7)$ & $27.6(5.5)$ & $28.3(5.9)$ \\
\hline \multicolumn{4}{|l|}{ Waist circumference, $\mathrm{cm}$} \\
\hline Men & $103.1(8.1)$ & $99.7(7.8)$ & $103.4(11.5)$ \\
\hline Women & $88.3(3.6)$ & $95.4(16.6)$ & $95.8(18.1)$ \\
\hline Serum insulin ${ }^{1}, \mathrm{pmol} / \mathrm{L}$ & $44.0(35.4,51.0)$ & $44.1(32.8,47.6)$ & $42.5(31.1,53.8)$ \\
\hline Serum C-peptide ${ }^{1}, \mathrm{nmol} / \mathrm{L}$ & $0.53(0.46,0.60)$ & $0.48(0.41,0.61)$ & $0.56(0.42,0.73)$ \\
\hline Glucose, mmol/L & $5.4(0.4)$ & $5.2(0.3)$ & $5.4(0.4)$ \\
\hline HOMA-IR ${ }^{1}$ & $0.81(0.68,0.98)$ & $0.84(0.62,0.91)$ & $0.82(0.59,1.04)$ \\
\hline Total cholesterol, mmol/L & $5.68(1.08)$ & $5.84(0.65)$ & $5.61(0.99)$ \\
\hline LDL-cholesterol, mmol/L & $3.99(0.94)$ & $3.95(0.68)$ & $3.78(0.94)$ \\
\hline $\mathrm{HDL}$-cholesterol, $\mathrm{mmol} / \mathrm{L}$ & $1.32(0.30)$ & $1.41(0.38)$ & $1.35(0.49)$ \\
\hline Triglyceride ${ }^{1}, \mathrm{mmol} / \mathrm{L}$ & $0.90(0.65,1.40)$ & $1.20(0.90,1.50)$ & $1.23(0.73,1.60)$ \\
\hline Total cholesterol/HDL-cholesterol ratio & $4.49(1.16)$ & $4.41(1.19)$ & $4.59(1.40)$ \\
\hline Users of oral contraceptives, N (\%) & $0(0)$ & $0(0)$ & $0(0)$ \\
\hline Smokers, N (\%) & $4(21)$ & $0(0)$ & $2(10)$ \\
\hline
\end{tabular}

Abbreviations: Saturated fatty acids (SFA), monounsaturated fatty acids (MUFA), homeostatic model assessment insulin resistance (HOMA-IR).

${ }^{1}$ Median (interquartile range). 
Table 5.3 Differences between assessed variables after 8 weeks of intervention diet

\begin{tabular}{|c|c|c|c|c|c|}
\hline & \multicolumn{3}{|c|}{$\begin{array}{l}\text { Outcome variables after } 8 \text { weeks of intervention } 1 \\
\qquad \text { Mean (se) }\end{array}$} & \multicolumn{2}{|c|}{$\begin{array}{l}\text { Differences between groups }{ }^{1} \\
\text { Mean }(95 \% \mathrm{Cl})\end{array}$} \\
\hline & $\begin{array}{l}\text { High SFA } \\
\mathrm{N}=19\end{array}$ & $\begin{array}{l}\text { High MUFA } \\
\mathrm{N}=18\end{array}$ & $\begin{array}{l}\text { Mediterranean } \\
\qquad \mathrm{N}=20\end{array}$ & MUFA-SFA & Mediterranean - MUFA \\
\hline Serum insulin, pmol/L & $39.7(2.6)$ & $45.6(2.7)$ & $40.8(2.5)$ & $5.9(-1.5 ; 13.4)$ & $-4.9(-12.2 ; 2.5)$ \\
\hline HOMA-IR & $0.76(0.05)$ & $0.86(0.05)$ & $0.78(0.05)$ & $0.11(-0.04 ; 0.25)$ & $-0.09(-0.23 ; 0.06)$ \\
\hline Serum C-peptide, $\mathrm{nmol} / \mathrm{L}$ & $0.52(0.02)$ & $0.55(0.02)$ & $0.51(0.02)$ & $0.03(-0.03 ; 0.08)$ & $-0.03(-0.09 ; 0.02)$ \\
\hline Glucose, $\mathrm{mmol} / \mathrm{L}$ & $5.33(0.06)$ & $5.25(0.06)$ & $5.28(0.06)$ & $-0.08(-0.25 ; 0.08)$ & $0.03(-0.14 ; 0.20)$ \\
\hline Total cholesterol, $\mathrm{mmol} / \mathrm{L}$ & $5.63(0.11)$ & $5.22(0.12)$ & $5.19(0.11)$ & $-0.41(-0.74 ;-0.09)$ & $-0.03(-0.35 ; 0.29)$ \\
\hline LDL-cholesterol, mmol/L & $3.90(0.09)$ & $3.52(0.10)$ & $3.42(0.09)$ & $-0.38(-0.65 ;-0.11)$ & $-0.09(-0.36 ; 0.17)$ \\
\hline HDL-cholesterol, mmol/L & $1.29(0.03)$ & $1.30(0.03)$ & $1.39(0.03)$ & $0.01(-0.08 ; 0.10)$ & $0.09(0.00 ; 0.18)$ \\
\hline Triglyceride, $\mathrm{mmol} / \mathrm{L}$ & $1.17(0.05)$ & $1.12(0.05)$ & $1.00(0.04)$ & $-0.05(-0.18 ; 0.08)$ & $-0.12(-0.25 ; 0.01)$ \\
\hline $\begin{array}{l}\text { Total cholesterol/HDL- } \\
\text { cholesterol ratio }\end{array}$ & $4.58(0.08)$ & $4.27(0.08)$ & $3.88(0.08)$ & $-0.30(-0.54 ;-0.07)$ & $-0.39(-0.62 ;-0.16)$ \\
\hline Body weight, kg & $79.6(0.3)$ & $80.4(0.3)$ & $79.8(0.3)$ & $0.8(-0.1 ; 1.8)$ & $-0.6(-1.6 ; 0.3)$ \\
\hline Waist circumference, $\mathrm{cm}$ & $94.5(0.8)$ & $96.2(0.9)$ & $94.8(0.8)$ & $1.7(-0.8 ; 4.1)$ & $-1.4(-3.8 ; 1.0)$ \\
\hline
\end{tabular}

Abbreviations: saturated fatty acids (SFA), monounsaturated fatty acids (MUFA), homeostatic model assessment insulin resistance (HOMA-IR).

${ }^{1}$ Adjusted for baseline levels, gender and participating in clamp measurements (yes/no).

observed. In the sub-group of 30 subjects who participated in the clamp study, the high MUFA-diet did not change insulin sensitivity compared with the SFA-diet $(+2.12$ $\mu \mathrm{mol} / \mathrm{min} / \mathrm{kgFFM}, 95 \% \mathrm{CI}-9.77 ; 14.00)$ and the Mediterranean did not affect insulin sensitivity differently than the high MUFA-diet $(+1.24 \mu \mathrm{mol} / \mathrm{min} / \mathrm{kgFFM}, 95 \% \mathrm{CI}$ $-10.83 ; 13.32)$.

Although body weight and waist circumference decreased slightly during the intervention period, they were not significantly different between the three intervention groups. Additional adjustment for changes in body weight and waist circumference led to similar conclusions for all outcome measurements (data not shown).

\section{Discussion}

In our controlled-feeding trial, a high MUFA-diet and a Mediterranean diet did not affect insulin sensitivity compared with a high SFA-diet. However, the high MUFAdiet reduced total- and LDL-cholesterol concentrations and total cholesterol/HDLcholesterol ratio. In addition, the Mediterranean diet increased HDL-cholesterol and reduced the ratio of total cholesterol/HDL-cholesterol.

Our study is the first to compare the effects of a Dutch high MUFA-diet with a Mediterranean diet with similar fatty-acid composition on serum lipids and insulin sensitivity. Strengths of our study are a low number of drop outs $(n=3)$ and a high compliance. A high compliance was demonstrated by the effect size of the high MUFAdiet on total cholesterol that was similar to that reported in previous controlled-feeding trials $[39,97]$. Other strengths are the methods we used to measure insulin sensitivity. 
We measured insulin sensitivity by insulin concentration and with the golden-standard hyperinsulinemic-euglycemic clamp procedure in half of the subjects. We also increased the precision of the measurements of insulin and serum lipid concentrations by taking the mean of two measurements sampled on two days, both at baseline and at the end of the study.

Regarding serum lipids, we found beneficial effects of the high MUFA-diet that correspond with the predicted differences between a high MUFA-diet and a SFA-diet using the model developed by Mensink et al. [39]. As this model is based on a metaanalysis of 60 controlled trials, this demonstrates the validity of our study.

Other Mediterranean diet intervention studies showed beneficial effects on serum lipids [30, 31]. However, none of these studies was able to disentangle the effects of separate Mediterranean components. Among these components, dietary fibre [95] and nuts [37] are expected to reduce concentrations of total- and LDL-cholesterol and triglycerides. The Mediterranean diet contained more dietary fibre and nuts than the high MUFA-diet, however it did not result in larger reductions in total- and LDL-cholesterol and triglyceride concentrations. This suggests that these additional effects are small, at least for total- and LDL-cholesterol. Regarding triglycerides our findings point at a stronger reduction with the Mediterranean diet compared with the high MUFA-diet.

The additional value of the Mediterranean diet compared with the MUFA-diet was shown for HDL-cholesterol and the total cholesterol/HDL-cholesterol ratio. These effects may be related to the higher consumption of alcohol and extra-virgin olive oil in the Mediterranean diet. One gram of alcohol was predicted to increase HDLcholesterol by $0.003 \mathrm{mmol} / \mathrm{L}$ [38]. Alcohol intake in the Mediterranean group was 2 energy-\% (7 gram alcohol) higher than in the high MUFA-group. This would have resulted in a difference of $0.02 \mathrm{mmol} / \mathrm{L}$ in HDL-cholesterol between the two groups. Extra-virgin olive oil is richer in polyphenols than refined olive oil that was used in the high MUFA-diet. When a diet with high-polyphenol olive oil was compared with the effect of a diet with low-polyphenol olive oil, the differential change in HDL-cholesterol was $0.02 \mathrm{mmol} / \mathrm{L}$, after 3 weeks [103]. However, the sum of predicted changes $(0.02$ $\mathrm{mmol} / \mathrm{L}$ for alcohol and $0.02 \mathrm{mmol} / \mathrm{L}$ for polyphenols from olive oil) can explain only half of the observed change in HDL-cholesterol $(0.09 \mathrm{mmol} / \mathrm{L})$. This suggests that other components of the Mediterranean diet play a role in improving HDL-cholesterol.

The triglyceride/HDL-cholesterol ratio was suggested to be an indicator of insulin resistance [104]. In our study, we were able to demonstrate favourable effects on serum lipids especially for HDL-cholesterol and triglycerides with the Mediterranean diet. However, we did not find an effect on insulin sensitivity. Rather, our MUFA-diet tended to increase insulin concentrations. Our lack of effect by the MUFA-diet is compatible with the results from Lovejoy et al. [105], but not with the reductions in fasting insulin by MUFA in the study of Perez-Jimenez [40] and the KANWU study [41]. Although design issues including study duration and diet contrast might partly be responsible, these can be rebutted. The duration of our study was not as long as that of other studies showing an effect of the Mediterranean diet on insulin sensitivity [30, 31]. However, our study was almost twice as long as the study of Perez-Jimenez, which showed an 
effect of a high MUFA-diet compared with a high SFA-diet [40]. The contrast in MUFA intake between the high MUFA-diet and the high SFA-diet in our study ( 9 energy-\%) was smaller than in the study of Perez-Jimenez (14 energy-\%) but larger than in the KANWU study (8 energy-\%) that showed an improvement in insulin sensitivity [41]. Also other Mediterranean diet intervention studies with smaller contrasts in MUFA intake than in our study increased insulin sensitivity $[30,31]$. Thus, the contrasts in MUFA intake between the intervention diets in our study were large enough to be able to show an effect on insulin sensitivity.

The results of a subgroup analysis within the KANWU study suggested that the effect of replacing SFA with MUFA was not present in the context of a high fat diet $(>37$ energy-\%) [41]. An observational study also reported an interaction between total fat intake $<37$ energy- $\%$ and fatty acid profile in association with markers of insulin sensitivity [106]. Total fat intake in our study was around that amount and this might explain the absence of an effect on insulin sensitivity. The KANWU study had a wide variation in total fat intake with $95 \%$ of their subjects in the range $29-45$ energy- $\%$ and hence was able to identify this post-hoc difference, while our study was fully controlled with a much smaller range. Therefore, it remains an option that needs to be explored, although the only other study on replacing SFA with MUFA against a relatively low total fat background gave a null result [105].

Another explanation for the absence of an effect in our study might be that subjects were on average insulin sensitive. One could speculate that our subjects would be less responsive to dietary changes than less insulin sensitive subjects. However, intervention studies showing an effect of a high MUFA-diet or a Mediterranean diet were performed not only in subjects that were less insulin sensitive than our subjects $[30,31]$, but also in healthy subjects $[40,41]$.

In conclusion, replacing a high SFA-diet with a high MUFA-diet improved serum lipids. Additionally, our study showed a beneficial effect of a Mediterranean diet on HDL-cholesterol and total cholesterol/HDL-cholesterol ratio. This implies that persons who adopt a Mediterranean diet could improve their serum lipids and hence their cardiovascular risk. We did not observe an effect of a high MUFA-diet or a Mediterranean diet on insulin sensitivity. The additional beneficial effect of the full Mediterranean pattern on insulin sensitivity requires further attention.

\section{Acknowledgements}

We would like to thank all participants, dieticians, students, kitchen- and laboratory personnel, Dr. Hans Verhagen (RIVM) and other co-workers for their motivation, dedication, and valuable contributions to the study. This study was funded by the Netherlands Heart Foundation and (2003B068), the Dutch Diabetes Research Foundation (20060052) and a grant of Unilever R\&D. clinicaltrials.gov NCT004051. 

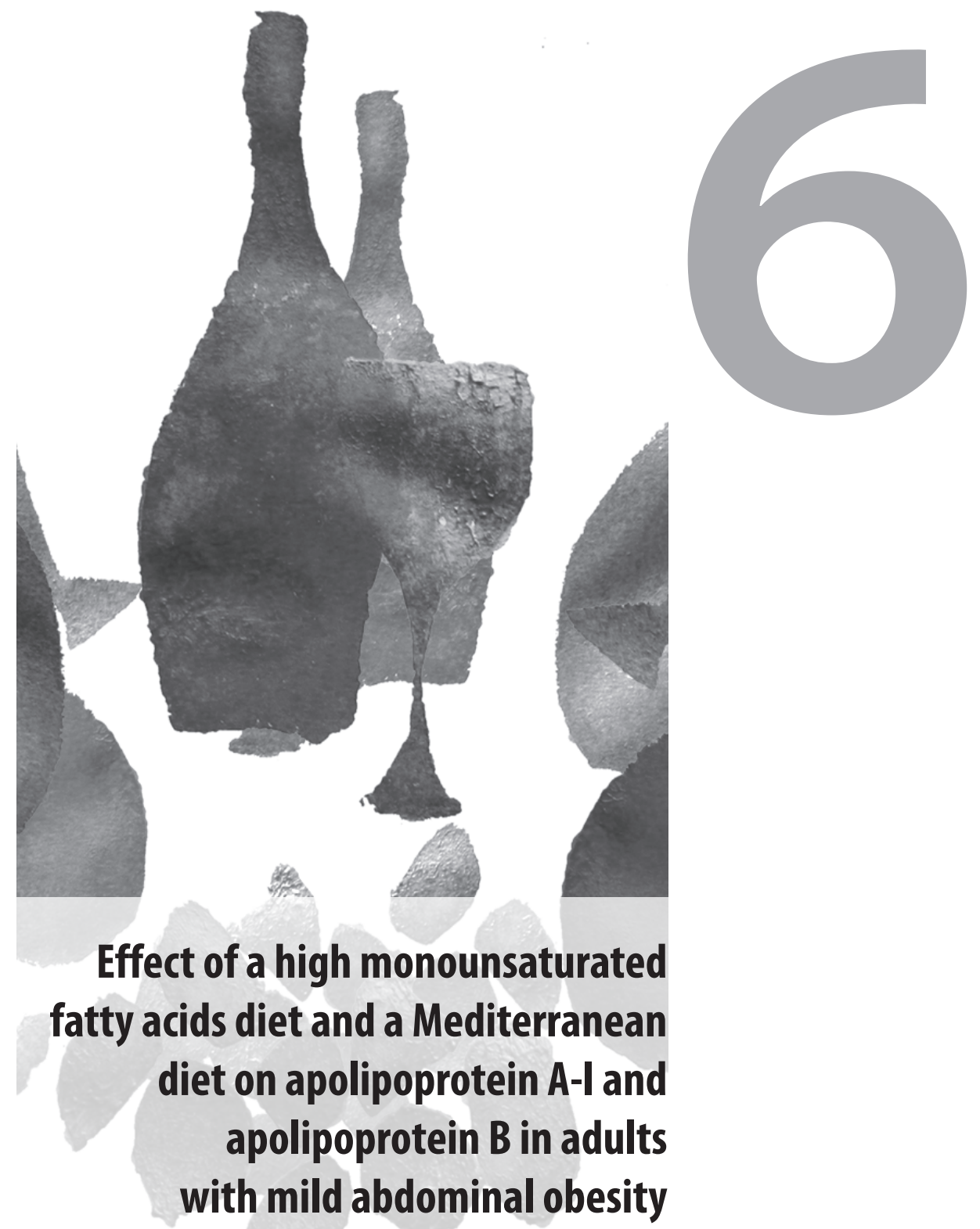

Marieke B. Bos, Jeanne H.M. de Vries, Edith J.M. Feskens, Lisette C.P.G.M. de Groot 


\begin{abstract}
Objective: To compare effects of replacing a diet high in saturated fatty acids (SFA) with a diet high in monounsaturated fatty acids (MUFA) or a Mediterranean diet on apolipoprotein A-I and B (apo A-I and apo B).

Design: Controlled-feeding trial, in 60 non-diabetics (40-65y) with mild abdominal obesity. Subjects received a high SFA-diet (SFA 19\% of total energy intake (energy-\%)), a high MUFA-diet (MUFA 20 energy-\%) or a Mediterranean diet (MUFA 21 energy- \%) for eight weeks.

Results: The high MUFA-diet and the Mediterranean diet did not affect apo A-I level compared with the high SFA-diet, despite significant changes in HDL-cholesterol by the Mediterranean diet. Compared with the high SFA-diet, the high MUFA-diet reduced apo B level $(-0.08 \mathrm{~g} / \mathrm{L}, 95 \% \mathrm{CI}-0.15 ;-0.01)$ and the apo B/apo A-I ratio $(-0.07 \mathrm{~g} / \mathrm{L}, 95 \% \mathrm{CI}$ $-0.14 ;-0.01)$. The Mediterranean diet further reduced apo B level and the apo B/apo A-I ratio, however compared with the high MUFA-diet these reductions were not statistically significant (apo B $-0.05 \mathrm{~g} / \mathrm{L}, 95 \% \mathrm{CI}-0.11 ; 0.02$, apo B/apo A-I ratio $0.05,95 \% \mathrm{CI}$ $-0.11 ; 0.02)$.

Conclusions: Replacing a high SFA-diet with a high MUFA or a Mediterranean diet did not affect apo A-I levels. The Mediterranean diet tended to improve apo B levels and the apo B/apo A-I ratio more than the high MUFA-diet.
\end{abstract}

\title{
Introduction
}

A recent controlled-feeding trial showed that replacing a diet high in saturated fatty acids (SFA) with a diet high in monounsaturated fatty acids (MUFA) or a Mediterranean diet decreased total cholesterol, LDL-cholesterol and triglyceride concentrations [107]. In addition, this trial showed that a Mediterranean diet increased HDL-cholesterol more than the diet high in MUFA did. Although not statistically significant, the effect of the Mediterranean diet on triglyceride concentrations was almost twice as large as the effect of the diet high in MUFA. This implies that the beneficial effect of a Mediterranean diet on HDL-cholesterol and triglyceride concentrations is not (only) due to the high MUFA content of a Mediterranean diet but to the cumulative effect of the Mediterranean components. A Mediterranean diet may cause a shift to a more favourable serum lipid profile. Accumulating evidence indicates that the ratio of apolipoprotein B (apo B)/ apolipoprotein-A-I (apo A-I) is superior to any of the cholesterol ratios for quantifying the lipoprotein related risk of cardiovascular disease [108]. This may be partly explained by the fact that apo B does not only reflect the number of LDL particles but also that of other atherogenic particles such as VLDL, IDL, and Lp(a). Therefore, we studied the effects of a Mediterranean diet on the apo B/apo A-1 ratio. In addition, we studied the effects of a Mediterranean diet on the apo A-I/HDL-cholesterol ratio and the log (triglyceride/HDL-cholesterol) ratio, which may reflect HDL particles size [109]. Increased particle size might also be a marker of lower cardiovascular disease risk [110].

\section{Subjects and Methods}

We carried out a controlled-feeding study [107], which included 60 non-diabetic subjects aged $40-65$ years with a BMI $\geq 25 \mathrm{~kg} / \mathrm{m}^{2}$ or a waist circumference $\geq 94 \mathrm{~cm}$ for men and $\geq 80 \mathrm{~cm}$ for women. All subjects received a Western-style diet high in SFA 
for a two weeks run-in period. After these two weeks, subjects were allocated to one of the three intervention diets: a high SFA-diet, a high MUFA-diet or a Mediterranean diet. This was done by randomization with stratification for gender and agreement to participate in additional clamp studies. Each subject consumed their diet for 8 weeks.

The high SFA-diet had the same composition as the run-in diet i.e. SFA (19.2 of total energy intake (energy-\%)) and MUFA (10.7 energy-\%). The high MUFA-diet contained a higher percentage of energy from MUFA (20.3 energy-\%) and a lower percentage of SFA (10.9 energy-\%) than the high SFA-diet. The high MUFA-diet was comparable with the high SFA-diet with regard to the composition of carbohydrates, protein, and dietary fibre. The Mediterranean diet had similar contents of MUFA (21.4 energy-\%) and SFA (10.7 energy-\%) as the high MUFA-diet. The Mediterranean diet consisted of a higher intake of vegetables, fruits, and a lower intake of dairy products, meat, and meat products than the high MUFA-diet. Some foods were exclusively provided in the Mediterranean diet, such as fatty fish (3 servings per week), unrefined grain products, nuts (15 g/day), legumes (40 g/day), and red wine (1 glass/day).

Fasting venous blood was taken at the end of the run-in period and at the end of the study. Concentrations of total and HDL-cholesterol and triglyceride were measured by a Dimension Clinical Chemistry System (Dade Behring Inc, USA). LDL-cholesterol was calculated with the formula of Friedewald et al. [98]. Apo A-I and apo B were measured by immunoturbidimetry (Synchron LX ${ }^{\oplus}$ Systems).

Differential changes between the high MUFA-diet and the high SFA-diet and between the Mediterranean diet and the high MUFA-diet were examined using analysis of covariance (ANCOVA) with predefined contrasts. Group differences in outcome measures determined after eight weeks of interventions, were adjusted for each participant's baseline value of the outcome measure [101], gender and participation in clamp measurements [102].

\section{Results and discussion}

Of the 60 participants enrolled in the study, 57 completed the trial. We found no substantial differences between the intervention groups in serum lipid concentrations or apo A-I, apo B or the apo B/apo A-I ratio at baseline (Table 6.1). The high MUFAdiet significantly reduced apo B level as well as the apo B/apo A-I ratio compared with the high SFA diet, reflecting significant reductions in LDL-cholesterol concentrations (Table 6.2). The Mediterranean diet further reduced apo B level and apo B/apo A-I ratio, however compared with the high MUFA-diet these reductions were not statistically significant (apo B p=0.18; apo B/apo A-I ratio $\mathrm{p}=0.14$ ). Changes in apo A-I were not different between the groups despite a clear increase in HDL-cholesterol with the Mediterranean diet. The apo A-1/HDL cholesterol ratio and the log (triglyceride/ HDL-cholesterol) ratio significantly decreased with the Mediterranean diet compared with the high MUFA-diet.

Our study suggests that a Mediterranean diet reduced apo B and the apo B/apo A-I ratio more than the high MUFA diet did. Although the additional reductions of this 
Table 6.1 Baseline characteristics of the 57 participants completing the study

\begin{tabular}{lccc}
\hline & & Mean $(\mathrm{sd})$ & \\
& High SFA & High MUFA & Mediterranean \\
& $\mathrm{N}=19$ & $\mathrm{~N}=18$ & $\mathrm{~N}=20$ \\
\hline Age, years & $52.0(7.2)$ & $58.9(5.1)$ & $56.8(6.0)$ \\
Men, N (\%) & $8(42)$ & $8(44)$ & $8(40)$ \\
Body mass index, $\mathrm{kg} / \mathrm{m}^{2}$ & $26.1(2.7)$ & $27.6(5.5)$ & $28.3(5.9)$ \\
Waist circumference, $\mathrm{cm}$ & & & \\
$\quad$ Men & $103.1(8.1)$ & $99.7(7.8)$ & $103.4(11.5)$ \\
$\quad$ Women & $88.3(3.6)$ & $95.4(16.6)$ & $95.8(18.1)$ \\
Total cholesterol, mmol/L & $5.68(1.08)$ & $5.84(0.65)$ & $5.61(0.99)$ \\
LDL-cholesterol, mmol/L & $3.99(0.94)$ & $3.95(0.68)$ & $3.78(0.94)$ \\
HDL-cholesterol, mmol/L & $1.32(0.30)$ & $1.41(0.38)$ & $1.35(0.49)$ \\
Triglyceride', mmol/L & $0.90(0.65,1.40)$ & $1.20(0.90,1.50)$ & $1.23(0.73,1.60)$ \\
Log (triglyceride/HDL-cholesterol ratio) & $-0.13(0.27)$ & $-0.06(0.22)$ & $-0.05(0.38)$ \\
Apolipoprotein A-I', g/L & $1.01(0.89,1.10)$ & $1.06(1.03,1.10)$ & $1.04(0.92,1.18)$ \\
Apolipoprotein B, g/L & $1.09(0.26)$ & $1.09(0.17)$ & $1.08(0.26)$ \\
Apolipoprotein B/apolipoprotein A-I ratio & $1.10(0.26)$ & $1.04(0.25)$ & $1.05(0.31)$ \\
Apolipoprotein A-1/HDL-cholesterol ratio ${ }^{1}$ & $0.80(0.67,0.89)$ & $0.78(0.69,0.84)$ & $0.83(0.67,0.99)$ \\
\hline
\end{tabular}

Abbreviations: Saturated fatty acids (SFA), monounsaturated fatty acids (MUFA).

${ }^{1}$ Median (interquartile range).

Table 6.2 Differences between assessed variables after 8 weeks of intervention diet

\begin{tabular}{|c|c|c|c|c|c|}
\hline & \multicolumn{3}{|c|}{$\begin{array}{l}\text { Outcome variables after } 8 \text { weeks of intervention' } \\
\text { Mean (se) }\end{array}$} & \multicolumn{2}{|c|}{$\begin{array}{l}\text { Differences between groups }{ }^{1} \\
\text { Mean }(95 \% C l)\end{array}$} \\
\hline & $\begin{array}{l}\text { High SFA } \\
\mathrm{N}=19\end{array}$ & $\begin{array}{l}\text { High MUFA } \\
\qquad \mathrm{N}=18\end{array}$ & $\begin{array}{l}\text { Mediterranean } \\
\qquad \mathrm{N}=20\end{array}$ & MUFA - SFA & Mediterranean - MUFA \\
\hline Total cholesterol, mmol/L & $5.63(0.11)$ & $5.22(0.12)$ & $5.19(0.11)$ & $-0.41(-0.74 ;-0.09)$ & $-0.03(-0.35 ; 0.29)$ \\
\hline LDL-cholesterol, mmol/L & $3.90(0.09)$ & $3.52(0.10)$ & $3.42(0.09)$ & $-0.38(-0.65 ;-0.11)$ & $-0.09(-0.36 ; 0.17)$ \\
\hline HDL-cholesterol, mmol/L & $1.29(0.03)$ & $1.30(0.03)$ & $1.39(0.03)$ & $0.01(-0.08 ; 0.10)$ & $0.09(0.00 ; 0.18)$ \\
\hline Triglyceride, $\mathrm{mmol} / \mathrm{L}$ & $1.17(0.05)$ & $1.12(0.05)$ & $1.00(0.04)$ & $-0.05(-0.18 ; 0.08)$ & $-0.12(-0.25 ; 0.01)$ \\
\hline $\begin{array}{l}\text { Total cholesterol/HDL- } \\
\text { cholesterol ratio }\end{array}$ & $4.58(0.08)$ & $4.27(0.08)$ & $3.88(0.08)$ & $-0.30(-0.54 ;-0.07)$ & $-0.39(-0.62 ;-0.16)$ \\
\hline $\begin{array}{l}\text { Log (triglyceride/HDL- } \\
\text { cholesterol ratio) }\end{array}$ & $-0.06(0.02)$ & $-0.10(0.02)$ & $-0.17(0.02)$ & $-0.04(-0.10 ; 0.01)$ & $-0.07(-0.12 ;-0.01)$ \\
\hline Apolipoprotein A-1, g/L & $1.06(0.01)$ & $1.07(0.01)$ & $1.06(0.01)$ & $0.01(-0.03 ; 0.05)$ & $0.00(-0.04 ; 0.04)$ \\
\hline Apolipoprotein B, g/L & $1.11(0.02)$ & $1.03(0.02)$ & $0.98(0.02)$ & $-0.08(-0.15 ;-0.01)$ & $-0.05(-0.11 ; 0.02)$ \\
\hline $\begin{array}{l}\text { Apolipoprotein } B / \\
\text { apolipoprotein A-1 ratio }\end{array}$ & $1.06(0.02)$ & $0.99(0.02)$ & $0.94(0.02)$ & $-0.07(-0.14 ;-0.01)$ & $-0.05(-0.11 ; 0.02)$ \\
\hline $\begin{array}{l}\text { Apolipoprotein A-1/HDL- } \\
\text { cholesterol ratio }\end{array}$ & $0.85(0.01)$ & $0.85(0.01)$ & $0.80(0.01)$ & $0.00(-0.03 ; 0.04)$ & $-0.06(-0.10 ;-0.02)$ \\
\hline
\end{tabular}

Abbreviations: saturated fatty acids (SFA), monounsaturated fatty acids (MUFA).

${ }^{1}$ Adjusted for baseline levels, gender and participating in clamp measurements (yes/no). 
diet are not statistically significant, we consider the effects clinically relevant. The effect size of the Mediterranean diets was almost twice as large as the effect size of the high MUFA-diet. Reduced apo B levels indicate a smaller number of atherogenic particles including LDL, VLDL, IDL, and Lp(a); and this implies reduced cardiovascular risk. Ambring et al. also found that a Mediterranean diet reduced apo B levels compared with a typical Swedish diet [32].

The Mediterranean diet significantly increased HDL-cholesterol concentration and decreased the apo A-1/HDL-cholesterol ratio compared with the high-MUFA diet; however, the apo A-I levels were not different between the two diets. These findings suggest that a Mediterranean diet has an effect on HDL particle size, with a shift towards larger more cholesterol-rich $\mathrm{HDL}_{2}$ particles [111]. In addition, the log (triglyceride/ HDL-cholesterol) ratio was shown to be negatively correlated with the proportion of $\mathrm{HDL}_{2}$ particles [109]. As the Mediterranean diet decreased the log (triglyceride/HDLcholesterol) ratio compared with the high MUFA diet, this also points at an increased proportion of $\mathrm{HDL}_{2}$ particles.

In conclusion, our results suggest that compared with a high-MUFA diet a Mediterranean dietary pattern may reduce apo B levels and hence reduce cardiovascular risk even further. In addition, an increase in $\mathrm{HDL}_{2}$ particles is suggested by the data, which may be important in reducing cardiovascular risk as well.

\section{Acknowledgements}

This study was funded by the Netherlands Heart Foundation and (2003B068), the Dutch Diabetes Research Foundation (20060052) and a grant of Unilever R\&D. clinicaltrials.gov NCT004051. 


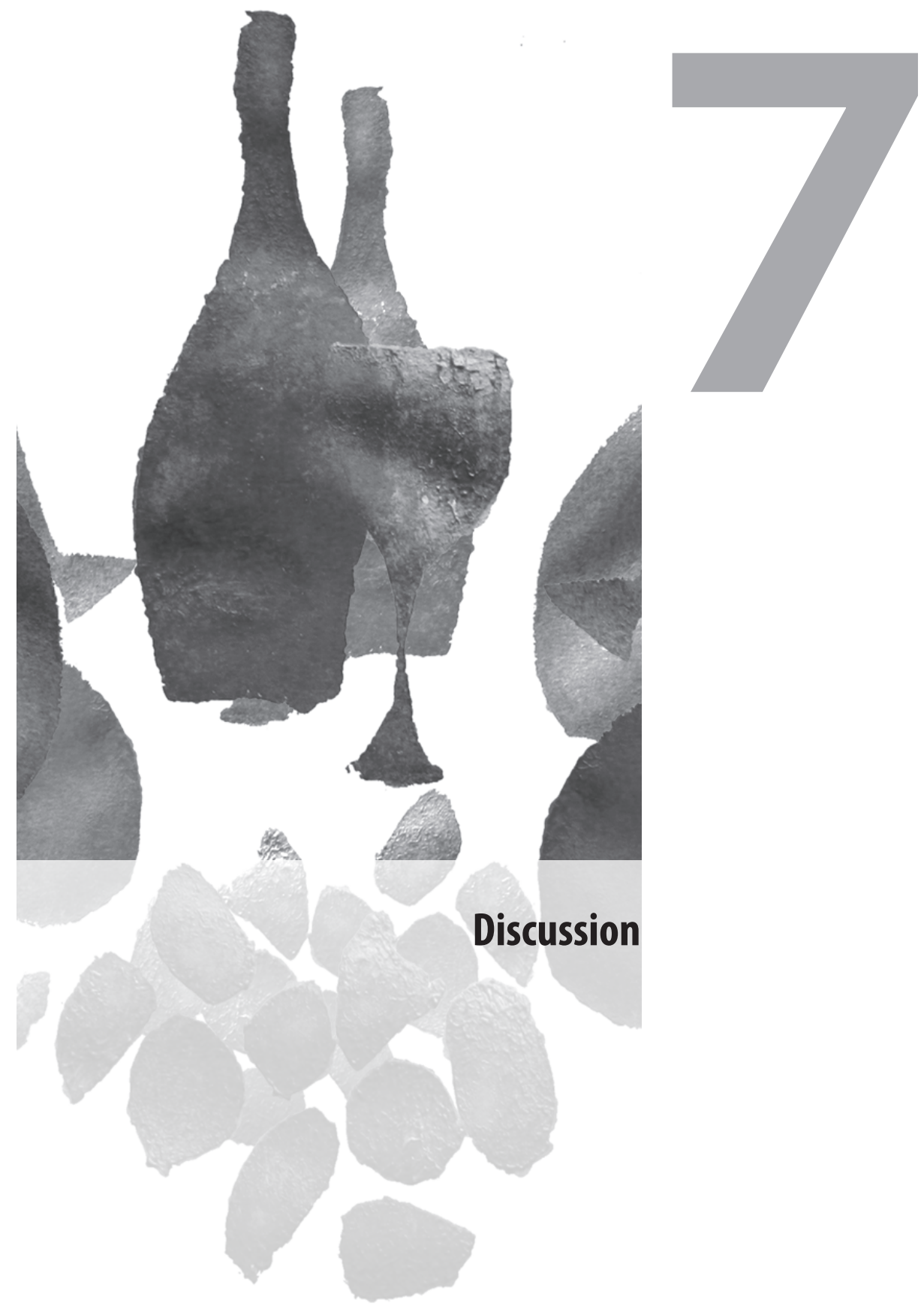


In this thesis, we studied whether a Mediterranean diet favourably affects the metabolic syndrome. According to our own observations this syndrome is highly prevalent in the Netherlands as it already affected approximately one million Dutch adults below 60 years of age in the 1990s. Therefore, the main findings of our observational studies and intervention study may have significant implications for public health. In this chapter, we will first summarise and critically address our own findings in view of the used methodology and findings from the literature. It is only after these reflections that we can present our overall conclusion, identify research needs and address the impact of a Mediterranean diet on public health.

\section{Main findings}

In both the SENECA study and the intervention study we find support for the hypothesis that a Mediterranean diet has a beneficial effect on two characteristics of the metabolic syndrome, namely on HDL-cholesterol and triglyceride concentrations (chapters 3 and 5). In addition, the findings of the SENECA study suggest that subjects with good adherence to a Mediterranean diet had a lower prevalence of the metabolic syndrome and a smaller waist circumference than subjects with poor adherence (chapter 3). In the CoDAM study (chapter 4), we did not find these associations. Neither did we find support for the hypothesis that a Mediterranean diet would improve glucose concentration, insulin sensitivity or blood pressure. Table 7.1 summarises the main findings of the two observational studies (SENECA study and CoDAM study) and the intervention study as presented in this thesis.

Table 7.1 Main findings

\begin{tabular}{lccc}
\hline Characteristics of the metabolic syndrome & \multicolumn{2}{c}{ Observational studies } & Intervention study \\
& SENECA & CoDAM & $\mathrm{N}=60$ \\
\hline Metabolic syndrome & $\mathrm{N}=1254$ & - & $\mathrm{N}=450$ \\
HDL-cholesterol & $\uparrow$ & - & $\uparrow$ \\
Triglyceride & $\uparrow$ & - & $\downarrow$ \\
Abdominal obesity & $\downarrow$ & - & na \\
Glucose & $\vdots$ & - & - \\
Blood pressure & - & - & na \\
\hline
\end{tabular}

Abbreviations: not applicable (na).

$\uparrow / \downarrow$ Beneficial association/effect.

Suggested beneficial association/effect (not significant).

- $\quad$ No beneficial association/effect. 


\section{Reflections}

\section{Mediterranean diet score}

tIn our observational studies, we examined dietary patterns rather than individual nutrients or food groups in relation to the metabolic syndrome. There are several reasons for studying dietary patterns. Meals are eaten with complex combinations of nutrients that may be interactive or synergistic [112]. As many nutrients are highly correlated, it is difficult to study their separate effects. In addition, the effect of a single nutrient may be too small to detect an effect whereas the cumulative effect of multiple nutrients in a dietary pattern may be large enough. In order to characterize the dietary pattern we used the Mediterranean diet score developed by Trichoupoulou et al. [25], which aims to assess the diet's degree of resemblance to a Mediterranean diet. This Mediterranean diet score includes nine Mediterranean components and uses sex-specific median intakes as cut-off values for the components: monounsaturated fatty acids (MUFA)/saturated fatty acids (SFA) ratio, cereals, legumes, fruits and nuts, vegetables, fish, dairy products, meat and poultry. As population-specific cut-off values are used, it has to be established to what extent such score truly reflects adherence to a Mediterranean type of diet. For example, in a Mediterranean diet that contains abundant olive oil a MUFA/SFA ratio larger than one is expected. However, in our studies we found median MUFA/SFA ratios smaller than one. We compared the cut-off values used in the SENECA and the CoDAM study with the mean intake of Mediterranean components by Greek men participating in the seven countries study (Crete) in 1960-1965, which resembles a traditional Mediterranean diet (Table 7.2).

Table 7.2 Comparison of the intakes of components of the Mediterranean diet score in men participating in the seven countries study (Crete, Greece), the SENECA and the CoDAM study

\begin{tabular}{|c|c|c|c|}
\hline $\begin{array}{l}\text { Components of the } \\
\text { Mediterranean diet score }\end{array}$ & $\begin{array}{l}\text { Mean intake }{ }^{1} \\
\text { Crete (1960-1965) }\end{array}$ & $\begin{array}{l}\text { Median intake }{ }^{1} \\
\text { (interquartile range) } \\
\text { SENECA }\end{array}$ & $\begin{array}{l}\text { Median intake }{ }^{1} \\
\text { (interquartile range) } \\
\text { CoDAM }\end{array}$ \\
\hline MUFA/SFA ratio & 3.7 & $0.98(0.83,1.23)$ & $0.84(0.78,0.92)$ \\
\hline Vegetables, g/day & 180 & $301^{2}(225,411)$ & $138(101,185)$ \\
\hline Legumes, g/day & 28 & $4^{3}(0,18)$ & $6(2,13)$ \\
\hline Fruits and nuts, g/day & $437^{4}$ & $201(110,336)$ & $195(108,300)$ \\
\hline Cereals, g/day & $565^{2}$ & $230(182,304)$ & $419^{2}(357,482)$ \\
\hline Fish, g/day & 17 & $29(14,59)$ & $10(4,16)$ \\
\hline Meat and poultry, g/day & 33 & $135(99,173)$ & $149(110,193)$ \\
\hline Dairy products, g/day & 234 & $323(177,502)$ & $248(137,417)$ \\
\hline Alcohol (10-50g/day), N (\%) & na & $271(43)$ & $135(49)$ \\
\hline
\end{tabular}

Abbreviations: monounsaturated fatty acids (MUFA), saturated fatty acids (SFA), not applicable (na).

${ }^{1}$ After adjustment for energy consumed (10.5 MJ).

${ }^{2}$ Also includes potatoes.

${ }^{3}$ Also includes nuts and seeds.

${ }^{4}$ Includes no nuts. 
Chapter 7 Discussion

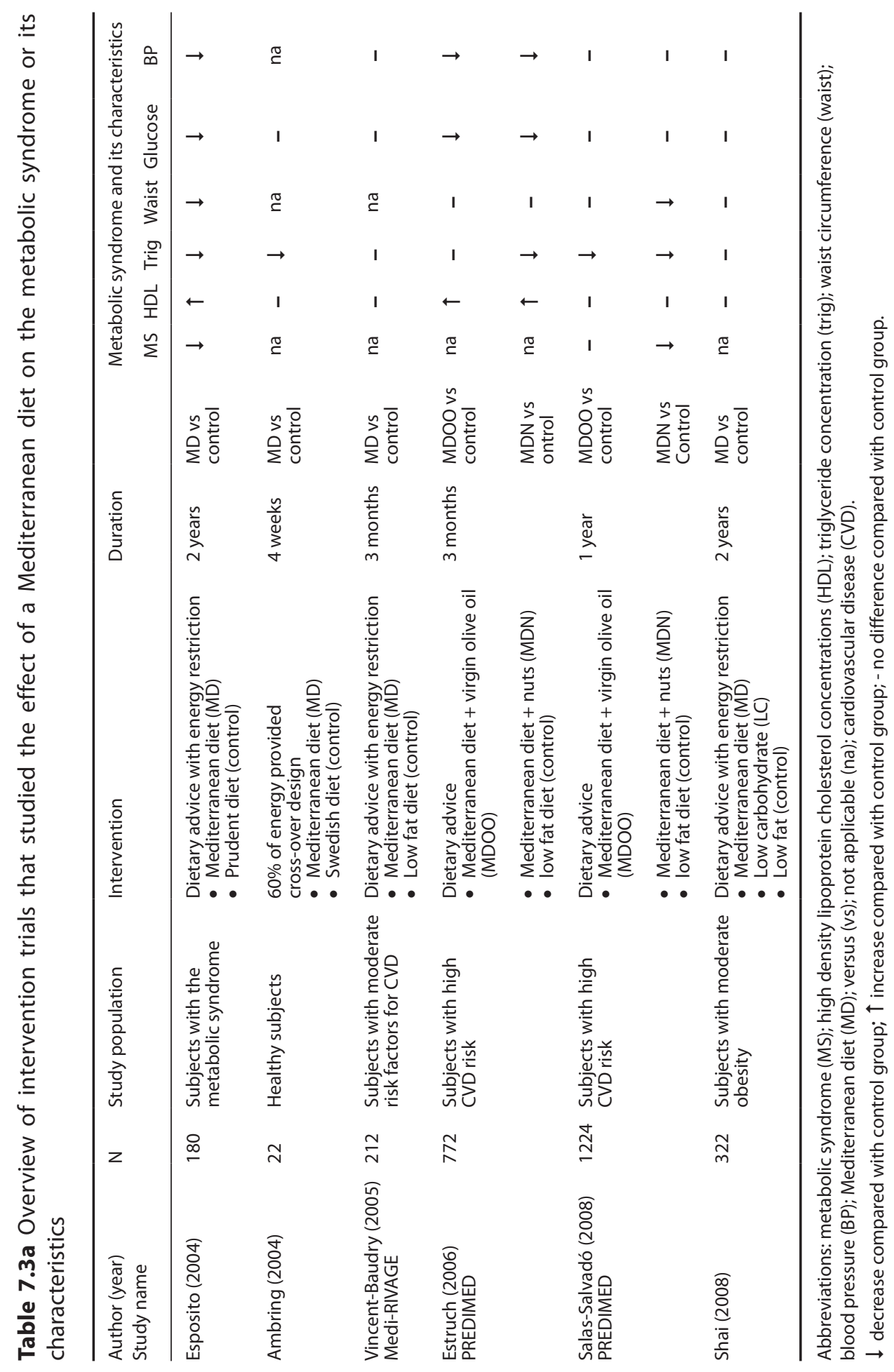


The MUFA/SFA ratio and the intakes of legumes, fruits and cereals in Crete were higher than those in our studies, while the intakes of meat and poultry and dairy products were lower. Using Cretan cut-off values would better discriminate between subjects with good and poor adherence to a traditional Mediterranean diet. However, components with ranges fully or largely above or below these cut-off values will not contribute to the discriminating power of the Mediterranean diet score [113]. As a consequence, this would result in few subjects with good adherence to a traditional Mediterranean diet in our studies and we would not have had power to find associations between a Mediterranean diet and the metabolic syndrome.

Although the cut-off values of neither the SENECA nor the CoDAM study are close to those of the Cretan study, the cut-off values in the SENECA study suggest that the diets of the European elderly were on average more Mediterranean than the diets of the subjects in the CoDAM study. Especially the cut-off values for MUFA/SFA ratio and fish intake were substantially higher in the SENECA study than in the CoDAM study. It may be due to these differences that we found more associations between a Mediterranean diet and the characteristics of the metabolic syndrome in the SENECA study than in the CoDAM study.

\section{Controlling dietary intakes in intervention studies}

Although the Mediterranean diet score implies that each of its components is equally important, we gave attention to the importance of MUFA intake in relation to the metabolic syndrome by comparing the effects of replacing a high SFA-diet with a high MUFA-diet or a Mediterranean diet. Such a comparative approach was also used in six other intervention studies (Table 7.3), but comparisons are hampered by differences or constraints in control diets, control of dietary intake, and weight maintenance.

First, most of these studies did not use a high SFA-diet as control diet but either a low fat diet $[31,60,82,114]$ or a prudent diet [30]. Second, in these studies dietary intake was not fully controlled by providing all foods. Instead, subjects were advised to eat a Mediterranean diet or a control diet. Only in the study of Ambring et al. [32] dietary intake was controlled by providing $60 \%$ of the daily energy needs. As a consequence of incomplete control of dietary intake in the Medi-RIVAGE study [114], the diet of subjects in the Mediterranean group was similar in macronutrient composition to the diet of subjects in the control group, which probably explains the lack of a differential effect on characteristics of the metabolic syndrome.

A third major difference between our controlled-feeding trial and related intervention studies was that most of the intervention studies advised their subjects to restrict their energy intake $[30,82,114]$, while we aimed to keep our subjects in energy balance during the trial. The recommended energy restriction resulted in weight loss in both the Mediterranean group and the control group in these studies. Therefore, they could not disentangle diet and weight loss effects. Two intervention studies aimed to maintain body weight during the study $[31,32,60]$. However, in the study by Ambring et al. a small but significant weight loss occurred during the study (mean weight loss (sd) $-0.7 \mathrm{~kg}(1.1))$ [32]. In the PREDIMED study [31, 60], no significant change in body weight occurred. In this study, subjects in the two Mediterranean groups were advised 
Chapter 7 | Discussion

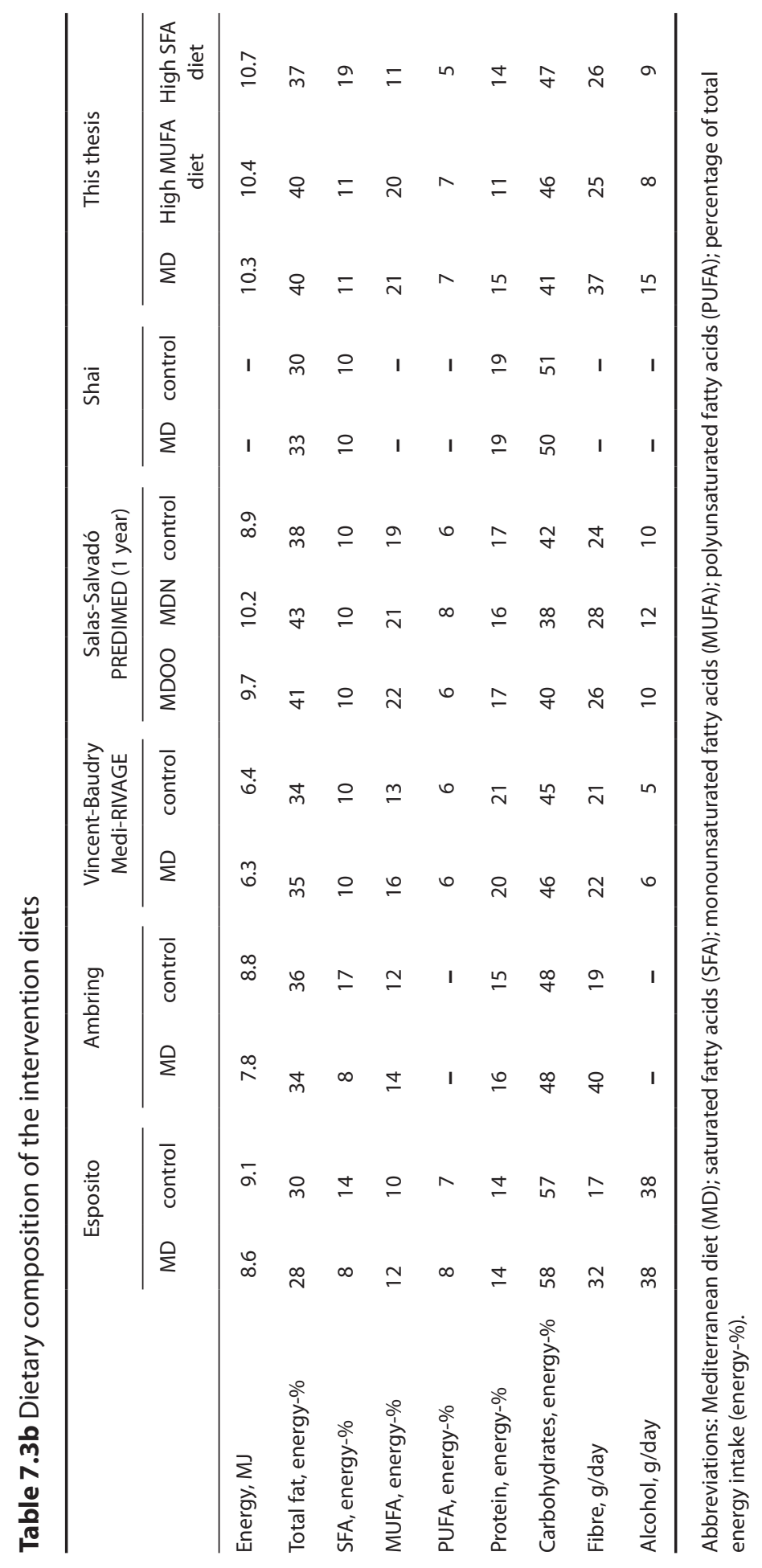


to consume a Mediterranean diet and were provided with supplemental products: either virgin olive oil or nuts. Although subjects in the control group were advised to consume a low fat diet, they also seem to have eaten according to a Mediterranean type of diet as they were living in a Mediterranean region in which olive oil consumption was high. Therefore, the effects found in this study might rather be due to the supplemented products (virgin olive oil or nuts) than to a Mediterranean diet as a whole.

In our intervention study, we aimed to overcome these shortcomings by introducing a large contrast between the Mediterranean diet and the high SFA-diet. To achieve this we replaced SFA with MUFA and we introduced other Mediterranean components: fatty fish (3 servings/week), unrefined-grain products, nuts (15 g/day), legumes ( $40 \mathrm{~g} /$ day), and red wine (1 glass/day), which were exclusively provided to the Mediterranean diet group. In addition, we controlled dietary intake by providing for $90 \%$ of the daily energy needs of our subjects. Although we tried to keep the subjects in energy balance during the trial, a small weight loss occurred (high SFA-diet: -1.5 kg (sd 1.4), high MUFA-diet: -0.6 kg (sd 1.4), Mediterranean diet: -1.4 kg (sd 1.8)). Between the intervention groups, the weight loss was not significantly different and adjustment of our analysis for weight loss did not change our conclusions.

\section{A Mediterranean diet and the metabolic syndrome}

Our observational studies showed no significant association between a Mediterranean diet and the metabolic syndrome. However, the results of the SENECA study suggested that the prevalence of the metabolic syndrome was lower in subjects with good adherence to a Mediterranean diet compared with subjects with poor adherence. We could not confirm this finding ourselves, as we did not study the effects of a Mediterranean diet on the metabolic syndrome in our intervention study. Yet, two other intervention studies do underpin SENECA's observations, by showing that a Mediterranean diet reduced the prevalence of the metabolic syndrome [30,60]. Further support comes from observational studies that showed that subjects with good adherence to a Mediterranean diet were less likely to have the metabolic syndrome (OR $0.81,95 \%$ CI 0.68 ; 0.98) [27] or that subjects with the highest adherence to a Mediterranean diet (Mediterranean diet score 6-9) had lower incidence rates of the metabolic syndrome (OR $0.20,95 \%$ CI 0.06 ; 0.63) compared with subjects with the lowest adherence (Mediterranean diet score 0-2) [28].

The findings of the CoDAM study do not support these inverse associations between a Mediterranean diet and the metabolic syndrome. This inconsistency between the SENECA study and the CoDAM study might be due to the differences in dietary cutoff values used as explained before.

In conclusion, our findings in the SENECA study, strengthened by observational and intervention studies carried out by others, suggest that a Mediterranean diet may be associated with the metabolic syndrome. 


\section{A Mediterranean diet and HDL-cholesterol concentrations, triglyceride concentrations and waist circumference}

The SENECA study showed that subjects with good adherence to a Mediterranean diet had higher HDL-cholesterol and lower triglyceride concentrations than subjects with poor adherence. Furthermore, the SENECA study suggested an inverse association between a Mediterranean diet and waist circumference. The findings on HDL-cholesterol and triglyceride concentrations are in line with the findings of our intervention study. In addition, our study showed that the beneficial effect of a Mediterranean diet on HDL-cholesterol concentration is probably not due to the high MUFA content of the diet but to the other components of a Mediterranean diet. One of the Mediterranean components that is expected to increase HDL-cholesterol concentration is alcohol. However, we calculated that alcohol intake only accounted for $22 \%(0.02 \mathrm{mmol} / \mathrm{L})$ of the observed increase in HDL-cholesterol concentration $(0.09 \mathrm{mmol} / \mathrm{L})$. Although the differential change in triglyceride concentrations was not significant between the Mediterranean diet and the high MUFA-diet $(-0.05$ $\mathrm{mmol} / \mathrm{L}, 95 \% \mathrm{CI}-0.18 ; 0.08)$ and between the high MUFA-diet and the high SFA-diet $(-0.12 \mathrm{mmol} / \mathrm{L}, 95 \% \mathrm{CI}-0.25 ; 0.01)$, the difference between the Mediterranean diet and the high SFA-diet was significant $(-0.17 \mathrm{mmol} / \mathrm{L}, 95 \% \mathrm{CI}-0.30 ;-0.04)$. Also, the difference in triglyceride concentration between the Mediterranean diet and the high MUFA-diet was almost twice as large as the difference between the high MUFA-diet and the high SFA-diet. These findings suggest that the effect of a Mediterranean diet on triglyceride concentration may not only be due to its high MUFA content but also to the other components of a Mediterranean diet. However, we also cannot exclude the possibility that weight loss during our trial influenced HDL-cholesterol and triglyceride concentrations.

The findings on HDL-cholesterol and triglyceride concentrations of the SENECA study are in agreement with the beneficial effects found in our intervention study and with those found in other intervention studies. The increase in HDL-cholesterol observed in our study $(0.09 \mathrm{mmol} / \mathrm{L})$ was similar to the increase in HDL-cholesterol observed after a 12 week intervention with a Mediterranean diet supplemented with olive oil or nuts $(0.08 \mathrm{mmol} / \mathrm{L}, 0.04 \mathrm{mmol} / \mathrm{L}$ respectively) [31] and to the increase after a 2 year intervention with a Mediterranean diet $(0.08 \mathrm{mmol} / \mathrm{L})$ [30] compared with the control diets. In addition, the decrease in triglyceride concentration observed in our study $(-0.17 \mathrm{mmol} / \mathrm{L})$ was similar to the decrease in triglyceride concentration observed after a 4 week intervention with a Mediterranean diet $(-0.20 \mathrm{mmol} / \mathrm{L})$ [32] and to the decrease after a 12 week intervention with a Mediterranean diet supplemented with nuts $(-0.15 \mathrm{mmol} / \mathrm{L})[31]$ and also with the decrease after a 2 year intervention with a Mediterranean diet $(-0.21 \mathrm{mmol} / \mathrm{L})$ [30] compared with the control diets. Furthermore, the inverse association between a Mediterranean diet and waist circumference suggested by the SENECA study is in line with a recent review that concluded that although inconsistency exists in the literature, the evidence points towards a possible role of the Mediterranean diet in preventing obesity [115].

The findings of the CoDAM study concerning HDL-cholesterol and triglyceride concentrations and waist circumference were neither in line with the findings of the 
SENECA study nor with those emerging from the intervention study. Besides the already mentioned differences in dietary cut-off values, this inconsistency may be due to the difference in contrast between subjects with good and poor adherence to a Mediterranean diet specifically regarding the Mediterranean components 'dairy products' and 'meat and poultry'. In the SENECA study, these two components of the Mediterranean diet score were the only components that were significantly associated with HDL-cholesterol, triglycerides or waist circumference. However, in the CoDAM study the mean intake of these two components did not differ significantly between subjects with good adherence to a Mediterranean diet (dairy products $294 \mathrm{~g} /$ day (sd 242 ), meat and poultry $128 \mathrm{~g} /$ day (sd 61)) and subjects with poor adherence (dairy products $327 \mathrm{~g} /$ day (sd 230), meat and poultry $135 \mathrm{~g} /$ day (sd 57)). As a result, the contrast between subjects with good and poor adherence to a Mediterranean diet may not have been sufficient to show an association with HDL-cholesterol and triglyceride concentrations or waist circumference in the CoDAM study.

In conclusion, our results together with the findings of other studies support the hypothesis that a Mediterranean diet beneficially affects HDL-cholesterol and triglyceride concentrations and suggest a beneficial effect on abdominal obesity.

\section{A Mediterranean diet and glucose metabolism}

Our studies did not find support for the hypothesis that a Mediterranean diet affects glucose metabolism. Especially for our intervention study, this might seem surprising as we designed our trial to include subjects who were likely to be insulin resistant by involving subjects with mild abdominal obesity. However, the mean insulin concentration of our subjects indicated that they were on average not insulin resistant. If baseline levels of insulin would have been higher, insulin levels might have decreased more in response to a Mediterranean diet.

Moreover, our trial was powered to detect a difference in insulin concentration of at least $8.5 \mathrm{pmol} / \mathrm{L}$ between the intervention groups. However, we did not observe such a large difference in our study. Therefore, the effect of a Mediterranean diet, if present, may be smaller than this $8.5 \mathrm{pmol} / \mathrm{L}$.

Other intervention studies did show that a Mediterranean diet improved glucose metabolism compared with the control diet in high-risk subjects $[30,31]$ but not in healthy subjects [32]. These findings support our idea that in particular subjects with high risk might be responsive to a Mediterranean diet. However, in the intervention study of Esposito et al. [30], the decrease in insulin concentration of $27 \mathrm{pmol} / \mathrm{L}$ induced by a Mediterranean diet may be partly due to weight loss and may therefore represent an indirect effect. The PREDIMED study did study the direct effect of a Mediterranean diet [31] and showed that a Mediterranean diet supplemented with virgin olive oil decreased insulin concentration by $17 \mathrm{pmol} / \mathrm{L}$ and that a Mediterranean diet supplemented with nuts reduced insulin concentration by $20 \mathrm{pmol} / \mathrm{L}$ compared with the control diet. However, as mentioned before, the differences in insulin concentrations observed in their study may largely be due to the supplemented products (virgin olive oil or nuts) rather than to a Mediterranean diet as a whole.

One observational study [29] supports our idea that subjects with high risk might 
be more responsive to a Mediterranean diet than healthy subjects, as it did not find an association between a Mediterranean diet and glucose concentration in a healthy Spanish population. However, findings of two other observational studies in healthy Greek and Italian populations do not support our idea, as one of them found an inverse association between a Mediterranean diet and glucose concentration [33] and the other one even found a positive association in women [116]. In addition, the findings of our observational studies did not show a beneficial association between a Mediterranean diet and glucose metabolism in neither the high-risk subjects of the CoDAM study nor in the apparently healthy elderly subjects of the SENECA study.

In conclusion, although we did not find support for the hypothesis that a Mediterranean diet affects glucose metabolism, we cannot exclude the possibility that an effect exists.

\section{A Mediterranean diet and blood pressure}

Only in the CoDAM study, we could study the association between a Mediterranean diet and blood pressure. However, we did not find an association. This result is similar to the results of two observational studies [116, 117]. However, other observational studies showed that a Mediterranean diet was associated with a reduced likelihood of having hypertension $[29,118]$ or a decrease in blood pressure levels [119]. In addition, intervention studies showed that a Mediterranean diet reduced blood pressure [30, $31,60]$.

In conclusion, although we did not find an association between a Mediterranean diet and blood pressure in the CoDAM study, the results of other studies indicate that a Mediterranean diet might reduce blood pressure.

\section{General conclusion}

The results of our studies together with the results of other studies support the hypothesis that a Mediterranean diet has a beneficial effect on two characteristics of the metabolic syndrome: HDL-cholesterol and triglyceride concentrations, and probably also on a third characteristic of the metabolic syndrome: waist circumference. Although our results do not support the hypothesis that a Mediterranean diet improves the other characteristics of the metabolic syndrome (glucose metabolism and blood pressure), we cannot exclude the possibility that a beneficial effect exists as well.

As this thesis finds support for a favourable effect on two out of five characteristics of the metabolic syndrome and also suggests a favourable effect on a third characteristic, we conclude that a Mediterranean diet may help to prevent the metabolic syndrome, and consequently diabetes mellitus type 2 and cardiovascular disease.

\section{Future studies and public health implications}

Our results together with results of other studies indicate that there is an association between a Mediterranean diet and the metabolic syndrome. However, there is limited evidence available from prospective cohort studies. Therefore, there is still a need for such studies. As in our observational studies, the method used to assess adherence 
to a Mediterranean diet should receive due attention. The use of median intakes of Mediterranean components as cut-off values in the Mediterranean diet score makes this score a useful tool to distinguish between subjects with good and poor adherence to a Mediterranean diet in any population. Especially in Northern European countries, a drawback of this method is that the cut-off values may not represent a traditional Mediterranean diet and that it does not take into account the full range of intake of the Mediterranean components due to the dichotomisation of the components. An alternative is to study the effect of a Mediterranean diet on the metabolic syndrome in further intervention studies, in which special attention should be given to abdominal obesity and glucose metabolism. Our results and the findings of others suggest that a Mediterranean diet may have a beneficial effect on abdominal obesity. However, as there is inconsistency in the evidence, further studies in this area are needed [115]. In these studies, also the indirect effect of a Mediterranean diet on glucose metabolism (mediated by weight loss) could be studied.

However, the direct effect of a Mediterranean diet on glucose metabolism can only be shown in a study where no weight loss occurs. This implies that subjects should be kept in energy balance for the full duration of the study. Therefore, a completely controlledfeeding trial would be an appropriate study design. The effects of a Mediterranean diet could then be compared with the effects of a Western style diet. In the power calculations, an effect size smaller than $8.5 \mathrm{pmol} / \mathrm{L}$ between the intervention groups should be taken into account. As we do not know yet whether high-risk subjects would be more responsive to a Mediterranean diet than healthy subjects, this intervention study should be performed in both populations. Such intervention studies will not only provide information about the effects of a Mediterranean diet on glucose metabolism but will, if extended with metabolic in-depth studies, also provide insight in the underlying mechanism.

As a Mediterranean diet may help preventing the metabolic syndrome (this thesis), reducing the incidence of diabetes mellitus type 2 [61] and reducing mortality rates from cardio vascular disease [22], we favour public health measures that stimulate eating a more Mediterranean type of diet. 


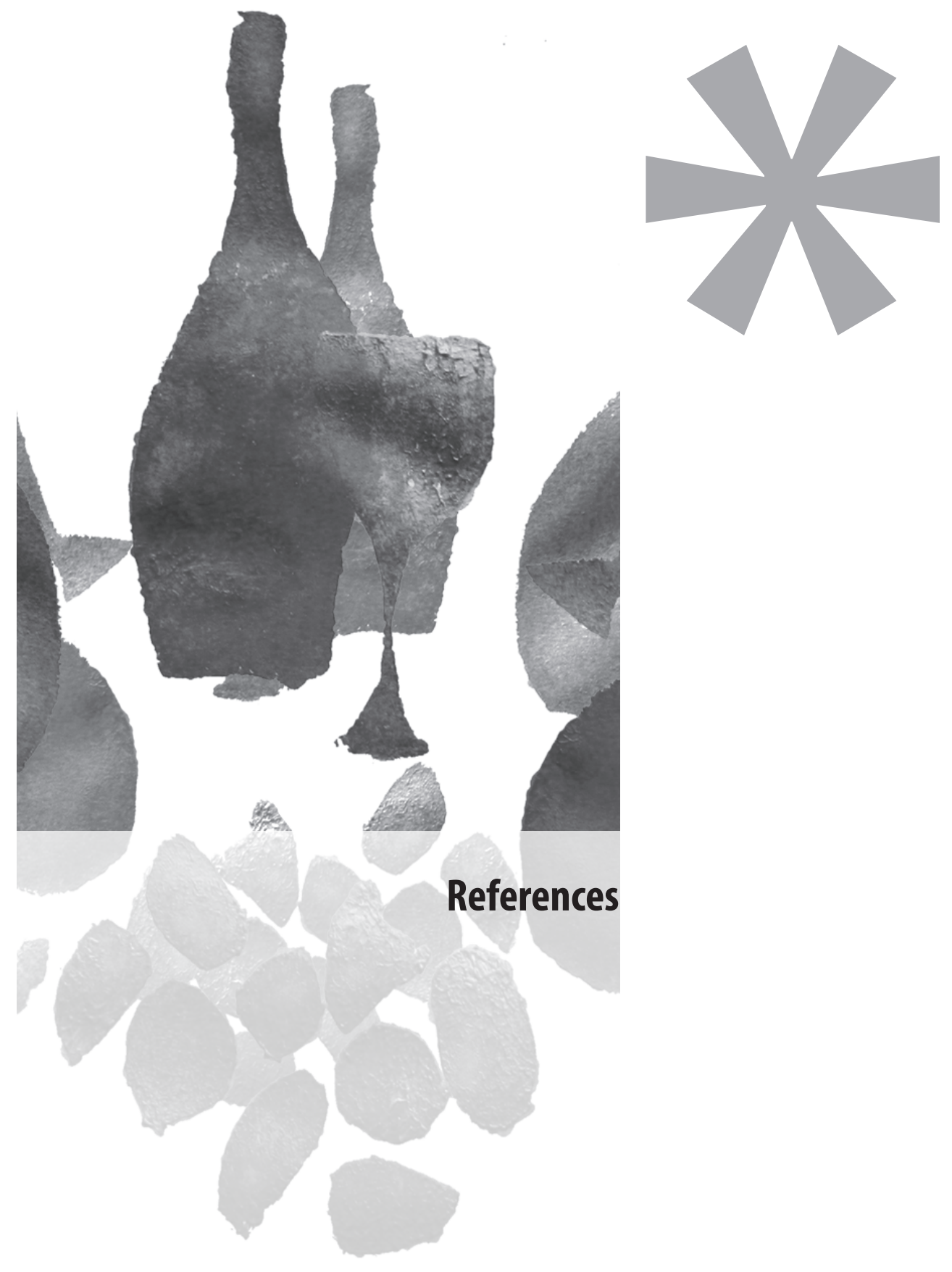


1. Reaven GM. Banting lecture 1988. Role of insulin resistance in human disease. Diabetes 1988;37:1595-1607.

2. Gami AS, Witt BJ, Howard DE, et al. Metabolic syndrome and risk of incident cardiovascular events and death: a systematic review and meta-analysis of longitudinal studies. J Am Coll Cardiol 2007;49:403-414.

3. Wannamethee SG, Shaper AG, Lennon L, Morris RW. Metabolic syndrome vs Framingham risk score for prediction of coronary heart disease, stroke, and type 2 diabetes mellitus. Arch Intern Med 2005;165:2644-2650.

4. Alberti KG, Zimmet PZ. Definition, diagnosis and classification of diabetes mellitus and its complications. Part 1: diagnosis and classification of diabetes mellitus provisional report of a WHO consultation. Diabet Med 1998;15:539553.

5. Balkau B, Charles MA. Comment on the provisional report from the WHO consultation. European Group for the Study of Insulin Resistance (EGIR). Diabet Med 1999;16:442-443.

6. NCEP. Executive summary of the third report of the National Cholesterol Education Program (NCEP) expert panel on detection, evaluation, and treatment of high blood cholesterol in adults (Adult Treatment Panel III). JAMA 2001;285:24862497.

7. Einhorn D, Reaven GM, Cobin RH, et al. American College of Endocrinology position statement on the insulin resistance syndrome. Endocr Pract 2003;9:237252.

8. Alberti KGMM, Zimmet P, Shaw J. The metabolic syndrome - a new worldwide definition. The Lancet 2005;366:1059.

9. Bach A, Serra-Majem L, Carrasco JL, et al. The use of indexes evaluating the adherence to the Mediterranean diet in epidemiological studies: a review. Public Health Nutr 2006;9:132-146.

10. Grundy SM, Cleeman JI, Daniels SR, et al. Diagnosis and management of the metabolic syndrome: An American Heart Association/National Heart, Lung, and Blood Institute scientific statement. Circulation 2005;112:2735-2752.

11. Grundy SM. Metabolic syndrome pandemic. Arterioscler Thromb Vasc Biol 2008;28:629-636.

12. Dekker JM, Girman C, Rhodes T, et al. Metabolic syndrome and 10-year cardiovascular disease risk in the Hoorn Study. Circulation 2005;112:666-673.

13. Guilherme A, Virbasius JV, Puri V, Czech MP. Adipocyte dysfunctions linking obesity to insulin resistance and type 2 diabetes. Nat Rev Mol Cell Biol 2008;9:367377.

14. Despres JP, Lemieux I. Abdominal obesity and metabolic syndrome. Nature 2006;444:881-887.

15. Olijhoek JK, Martens FM, Banga JD, Visseren FL. [The metabolic syndrome: a cluster of vascular risk factors]. Ned Tijdschr Geneeskd 2005;149:859-865. 
16. Muoio DM, Newgard CB. Mechanisms of disease: molecular and metabolic mechanisms of insulin resistance and beta-cell failure in type 2 diabetes. Nat Rev Mol Cell Biol 2008;9:193-205.

17. Cornier MA, Dabelea D, Hernandez TL, et al. The metabolic syndrome. Endocr Rev 2008;29:777-822.

18. Ginsberg HN, Zhang YL, Hernandez-Ono A. Regulation of plasma triglycerides in insulin resistance and diabetes. Arch Med Res 2005;36:232-240.

19. Burgers JS, Simoons ML, Hoes AW, Stehouwer CD, Stalman WA. [Guideline 'Cardiovascular Risk Management']. Ned Tijdschr Geneeskd 2007;151:10681074.

20. NHG-standaard. Cardiovasculair Risicomanagement. Huisarts en wetenschap 2006.

21. Guidelines for a healthy diet 2006. The Hague: Health Council of the Netherlands, 2006.

22. Sofi F, Cesari F, Abbate R, Gensini GF, Casini A. Adherence to Mediterranean diet and health status: meta-analysis. BMJ 2008;337:a1344.

23. Manios Y, Detopoulou V, Visioli F, Galli C. Mediterranean diet as a nutrition education and dietary guide: misconceptions and the neglected role of locally consumed foods and wild green plants. Forum Nutr 2006;59:154-170.

24. Serra-Majem L, Trichopoulou A, Ngo de la Cruz J, et al. Does the definition of the Mediterranean diet need to be updated? Public Health Nutr 2004;7:927-929.

25. Trichopoulou A, Costacou T, Bamia C, Trichopoulos D. Adherence to a Mediterranean diet and survival in a Greek population. N Engl J Med 2003;348:2599-2608.

26. Willett WC, Sacks F, Trichopoulou A, et al. Mediterranean diet pyramid: a cultural model for healthy eating. Am J Clin Nutr 1995;61:1402S-1406S.

27. Panagiotakos DB, Pitsavos C, Chrysohoou C, et al. Impact of lifestyle habits on the prevalence of the metabolic syndrome among Greek adults from the ATTICA study. Am Heart J 2004;147:106-112.

28. Tortosa A, Bes-Rastrollo M, Sanchez-Villegas A, Basterra-Gortari FJ, NunezCordoba JM, Martinez-Gonzalez MA. Mediterranean diet inversely associated with the incidence of metabolic syndrome: the SUN prospective cohort. Diabetes Care 2007;30:2957-2959.

29. Alvarez Leon EE, Henriquez P, Serra-Majem L. Mediterranean diet and metabolic syndrome: a cross-sectional study in the Canary Islands. Public Health Nutr 2006;9:1089-1098.

30. Esposito K, Marfella R, Ciotola M, et al. Effect of a Mediterranean-style diet on endothelial dysfunction and markers of vascular inflammation in the metabolic syndrome: A randomized trial. JAMA 2004;292:1440-1446. 
31. Estruch R, Martinez-Gonzalez MA, Corella D, et al. Effects of a Mediterraneanstyle diet on cardiovascular risk factors: a randomized trial. Ann Intern Med 2006;145:1-11.

32. Ambring A, Friberg P, Axelsen M, et al. Effects of a Mediterranean-inspired diet on blood lipids, vascular function and oxidative stress in healthy subjects. Clin Sci (Lond) 2004;106:519-525.

33. Panagiotakos DB, Tzima N, Pitsavos C, et al. The association between adherence to the Mediterranean diet and fasting indices of glucose homoeostasis: the ATTICA Study. J Am Coll Nutr 2007;26:32-38.

34. Riccardi G, Giacco R, Rivellese AA. Dietary fat, insulin sensitivity and the metabolic syndrome. Clinical Nutrition 2004;23:447.

35. Harris WS. n-3 fatty acids and serum lipoproteins: human studies. Am J Clin Nutr 1997;65:1645S-1654S.

36. McAuley KA, Mann JI. Nutritional determinants of insulin resistance. J Lipid Res 2006;47:1668-1676.

37. Mukuddem-Petersen J, Oosthuizen W, Jerling JC. A systematic review of the effects of nuts on blood lipid profiles in humans. J Nutr 2005;135:2082-2089.

38. Rimm EB, Williams P, Fosher K, Criqui M, Stampfer MJ. Moderate alcohol intake and lower risk of coronary heart disease: meta-analysis of effects on lipids and haemostatic factors. BMJ 1999;319:1523-1528.

39. Mensink RP, Zock PL, Kester AD, Katan MB. Effects of dietary fatty acids and carbohydrates on the ratio of serum total to HDL cholesterol and on serum lipids and apolipoproteins: a meta-analysis of 60 controlled trials. Am J Clin Nutr 2003;77:1146-1155.

40. Perez-Jimenez F, Lopez-Miranda J, Pinillos MD, et al. A Mediterranean and a high-carbohydrate diet improve glucose metabolism in healthy young persons. Diabetologia 2001;44:2038-2043.

41. Vessby B, Uusitupa M, Hermansen K, et al. Substituting dietary saturated for monounsaturated fat impairs insulin sensitivity in healthy men and women: The KANWU study. Diabetologia 2001;44:312-319.

42. Hu G, Qiao Q, Tuomilehto J, Balkau B, Borch-Johnsen K, Pyorala K. Prevalence of the metabolic syndrome and its relation to all-cause and cardiovascular mortality in nondiabetic European men and women. Arch Intern Med 2004;164:10661076 .

43. Isomaa $\mathrm{B}$, Almgren $\mathrm{P}$, Tuomi $\mathrm{T}$, et al. Cardiovascular morbidity and mortality associated with the metabolic syndrome. Diabetes Care 2001;24:683-689.

44. Lakka HM, Laaksonen DE, Lakka TA, et al. The metabolic syndrome and total and cardiovascular disease mortality in middle-aged men. JAMA 2002;288:27092716. 
45. Sattar N, Gaw A, Scherbakova O, et al. Metabolic syndrome with and without C-reactive protein as a predictor of coronary heart disease and diabetes in the West of Scotland Coronary Prevention Study. Circulation 2003;108:414-419.

46. Kahn R, Buse J, Ferrannini E, Stern M. The metabolic syndrome: time for a critical appraisal. Joint statement from the American Diabetes Association and the European Association for the Study of Diabetes. Diabetologia 2005;48:16841699.

47. McNeill AM, Rosamond WD, Girman CJ, et al. The Metabolic Syndrome and 11-Year Risk of Incident Cardiovascular Disease in the Atherosclerosis Risk in Communities Study. Diabetes Care 2005;28:385-390.

48. Balkau B, Charles MA, Drivsholm T, et al. Frequency of the WHO metabolic syndrome in European cohorts, and an alternative definition of an insulin resistance syndrome. Diabetes Metab 2002;28:364-376.

49. Lemieux I, Pascot A, Couillard C, et al. Hypertriglyceridemic Waist : A marker of the atherogenic metabolic triad (hyperinsulinemia; hyperapolipoprotein B; small, dense LDL) in men? Circulation 2000;102:179-184.

50. Houterman S, Verschuren WMM, Oomen CM, Boersma-Cobbaert CM, Kromhout D. Trends in total and high density lipoprotein cholesterol and their determinants in The Netherlands between 1993 and 1997. Int. J. Epidemiol. 2001;30:1063-1070.

51. Lean ME, Han TS, Seidell JC. Impairment of health and quality of life in people with large waist circumference. Lancet 1998;351:853-856.

52. Pinto-Sietsma SJ, Janssen WM, Hillege HL, Navis G, De Zeeuw D, De Jong PE. Urinary albumin excretion is associated with renal functional abnormalities in a nondiabetic population. J Am Soc Nephrol 2000;11:1882-1888.

53. Van Loon AJ, Tijhuis M, Picavet HS, Surtees PG, Ormel J. Survey non-response in the Netherlands: effects on prevalence estimates and associations. Ann Epidemiol 2003;13:105-110.

54. Visscher TL, Seidell JC. Time trends (1993-1997) and seasonal variation in body mass index and waist circumference in the Netherlands. Int J Obes Relat Metab Disord 2004;28:1309-1316.

55. Visser M, Pluijm SM, van der Horst MH, Poppelaars JL, Deeg DJ. [Lifestyle of Dutch people aged 55-64 years less healthy in 2002/'03 than in 1992/'93]. Ned Tijdschr Geneeskd 2005;149:2973-2978.

56. Toth MJ, Tchernof A, Sites CK, Poehlman ET. Menopause-related changes in body fat distribution. Ann N Y Acad Sci 2000;904:502-506.

57. Sundstrom J, Riserus U, Byberg L, Zethelius B, Lithell H, Lind L. Clinical value of the metabolic syndrome for long term prediction of total and cardiovascular mortality: prospective, population based cohort study. BMJ 2006;332:878-882.

58. Grundy SM. Does a diagnosis of metabolic syndrome have value in clinical practice? Am J Clin Nutr 2006;83:1248-1251. 
59. Giugliano D, Ceriello A, Esposito K. Are there specific treatments for the metabolic syndrome? Am J Clin Nutr 2008;87:8-11.

60. Salas-Salvado J, Fernandez-Ballart J, Ros E, et al. Effect of a Mediterranean diet supplemented with nuts on metabolic syndrome status: one-year results of the PREDIMED randomized trial. Arch Intern Med 2008;168:2449-2458.

61. Martinez-Gonzalez MA, de la Fuente-Arrillaga C, Nunez-Cordoba JM, et al. Adherence to Mediterranean diet and risk of developing diabetes: prospective cohort study. BMJ 2008;336:1348-1351.

62. Roman B, Carta L, Martinez-Gonzalez MA, Serra-Majem L. Effectiveness of the Mediterranean diet in the elderly. Clin Interv Aging 2008;3:97-109.

63. de Groot LCPGM, van Staveren WA. Nutrition and the elderly. Euronut Report 11. Wageningen, 1988.

64. Teuscher AU, Reinli K, Teuscher A. Glycaemia and insulinaemia in elderly European subjects (70-75 years). Diabet Med 2001;18:150-153.

65. van 't Hof MA, Hautvast JG, Schroll M, Vlachonikolis IG. Design, methods and participation. Euronut SENECA investigators. Eur J Clin Nutr 1991;45 Suppl $3: 5-22$.

66. Arab L, Wittler M, Schettler G. European food composition tables in translation. Berlin Heidelberg: Springer-Verlag, 1987.

67. Haveman-Nies A, de Groot LCPGM, Burema J, Cruz JA, Osler M, van Staveren WA. Dietary quality and lifestyle factors in relation to 10 -year mortality in older Europeans: the SENECA study. Am J Epidemiol 2002;156:962-968.

68. van Staveren WA, de Groot LCPGM, Haveman-Nies A. The SENECA study: potentials and problems in relating diet to survival over 10 years. Public Health Nutr 2002;5:901-905.

69. Knoops KTB, de Groot LCPGM, Kromhout D, et al. Mediterranean diet, lifestyle factors, and 10-year mortality in elderly European men and women: The HALE Project. JAMA 2004;292:1433-1439.

70. Kafatos A, Schlienger JL, Deslypere JP, Ferro-Luzzi A, Amorim Cruz JA. Nutritional status: serum lipids. Euronut SENECA investigators. Eur J Clin Nutr 1991;45 Suppl 3:53-61.

71. Voorrips LE, Ravelli AC, Dongelmans PC, Deurenberg P, Van Staveren WA. A physical activity questionnaire for the elderly. Med Sci Sports Exerc 1991;23:974979.

72. Barros AJ, Hirakata VN. Alternatives for logistic regression in cross-sectional studies: an empirical comparison of models that directly estimate the prevalence ratio. BMC Med Res Methodol 2003;3:21.

73. Bach-Faig A, Geleva D, Carrasco JL, Ribas-Barba L, Serra-Majem L. Evaluating associations between Mediterranean diet adherence indexes and biomarkers of diet and disease. Public Health Nutr 2006;9:1110-1117. 
74. Drouillet P, Balkau B, Charles MA, et al. Calcium consumption and insulin resistance syndrome parameters. Data from the Epidemiological Study on the Insulin Resistance Syndrome (DESIR). Nutr Metab Cardiovasc Dis 2007;17:486492.

75. Liu S, Song Y, Ford ES, Manson JE, Buring JE, Ridker PM. Dietary calcium, vitamin $\mathrm{D}$, and the prevalence of metabolic syndrome in middle-aged and older U.S. women. Diabetes Care 2005;28:2926-2932.

76. Snijder MB, van Dam RM, Stehouwer CD, Hiddink GJ, Heine RJ, Dekker JM. A prospective study of dairy consumption in relation to changes in metabolic risk factors: the Hoorn Study. Obesity (Silver Spring) 2008;16:706-709.

77. Nicklas TA, Farris RP, Myers L, Berenson GS. Impact of meat consumption on nutritional quality and cardiovascular risk factors in young adults: the Bogalusa Heart Study. J Am Diet Assoc 1995;95:887-892.

78. Slattery ML, Jacobs DR, Jr., Hilner JE, et al. Meat consumption and its associations with other diet and health factors in young adults: the CARDIA study. Am J Clin Nutr 1991;54:930-935.

79. Mensink RP, Katan MB. Effect of dietary fatty acids on serum lipids and lipoproteins. A meta-analysis of 27 trials. Arterioscler Thromb 1992;12:911-919.

80. Kris-Etherton PM, Yu-Poth S, Sabate J, Ratcliffe HE, Zhao G, Etherton TD. Nuts and their bioactive constituents: effects on serum lipids and other factors that affect disease risk. Am J Clin Nutr 1999;70:504S-511S.

81. Flight I, Clifton P. Cereal grains and legumes in the prevention of coronary heart disease and stroke: a review of the literature. Eur J Clin Nutr 2006;60:11451159.

82. Shai I, Schwarzfuchs D, Henkin Y, et al. Weight loss with a low-carbohydrate, Mediterranean, or low-fat diet. N Engl J Med 2008;359:229-241.

83. Wagemakers JJ, Prynne CJ, Stephen AM, Wadsworth ME. Consumption of red or processed meat does not predict risk factors for coronary heart disease; results from a cohort of British adults in 1989 and 1999. Eur J Clin Nutr 2007:1-9.

84. Haveman-Nies A, Tucker KL, de Groot LCPGM, Wilson PWF, van Staveren WA. Evaluation of dietary quality in relationship to nutritional and lifestyle factors in elderly people of the US Framingham Heart Study and the European SENECA study. Eur J Clin Nutr 2001;55:870-880.

85. Hu G, Qiao Q, Tuomilehto J, Eliasson M, Feskens EJ, Pyorala K. Plasma insulin and cardiovascular mortality in non-diabetic European men and women: a meta-analysis of data from eleven prospective studies. Diabetologia 2004;47:12451256.

86. Giugliano D, Esposito K. Mediterranean diet and metabolic diseases. Curr Opin Lipidol 2008;19:63-68. 
87. Ocke MC, Bueno-de-Mesquita HB, Goddijn HE, et al. The Dutch EPIC food frequency questionnaire. I. Description of the questionnaire, and relative validity and reproducibility for food groups. Int J Epidemiol 1997;26 Suppl 1:S37-48.

88. Ocke MC, Bueno-de-Mesquita HB, Pols MA, Smit HA, van Staveren WA, Kromhout D. The Dutch EPIC food frequency questionnaire. II. Relative validity and reproducibility for nutrients. Int J Epidemiol 1997;26 Suppl 1:S49-58.

89. Wendel-Vos GC, Schuit AJ, Saris WH, Kromhout D. Reproducibility and relative validity of the short questionnaire to assess health-enhancing physical activity. J Clin Epidemiol 2003;56:1163-1169.

90. Ferrari P, Slimani N, Ciampi A, et al. Evaluation of under- and overreporting of energy intake in the 24-hour diet recalls in the European Prospective Investigation into Cancer and Nutrition (EPIC). Public Health Nutr 2002;5:1329-1345.

91. Osler M, Schroll M. Diet and mortality in a cohort of elderly people in a north European community. Int J Epidemiol 1997;26:155-159.

92. Buijsse B, Hollman PCH, Kafatos A, et al. Diet, biomarkers, major risk factors, and 40-year coronary mortality in the Cretan and Zutphen cohorts of the seven countries study Submitted for publication.

93. van Dam RM, Willett WC, Rimm EB, Stampfer MJ, Hu FB. Dietary fat and meat intake in relation to risk of type 2 diabetes in men. Diabetes Care 2002;25:417424.

94. Feskens EJ, Loeber JG, Kromhout D. Diet and physical activity as determinants of hyperinsulinemia: the Zutphen Elderly Study. Am J Epidemiol 1994;140:350360.

95. Brown L, Rosner B, Willett WW, Sacks FM. Cholesterol-lowering effects of dietary fiber: a meta-analysis. Am J Clin Nutr 1999;69:30-42.

96. Feunekes GI, Van Staveren WA, De Vries JH, Burema J, Hautvast JG. Relative and biomarker-based validity of a food-frequency questionnaire estimating intake of fats and cholesterol. Am J Clin Nutr 1993;58:489-496.

97. Mensink RP, de Groot MJ, van den Broeke LT, Severijnen-Nobels AP, Demacker $\mathrm{PN}$, Katan MB. Effects of monounsaturated fatty acids v complex carbohydrates on serum lipoproteins and apoproteins in healthy men and women. Metabolism 1989;38:172-178.

98. Friedewald WT, Levy RI, Fredrickson DS. Estimation of the concentration of low-density lipoprotein cholesterol in plasma, without use of the preparative ultracentrifuge. Clin Chem 1972;18:499-502.

99. DeFronzo RA, Tobin JD, Andres R. Glucose clamp technique: a method for quantifying insulin secretion and resistance. Am J Physiol 1979;237:E214-223.

100. Fields DA, Goran MI, McCrory MA. Body-composition assessment via airdisplacement plethysmography in adults and children: a review. Am J Clin Nutr 2002;75:453-467. 
101. Vickers AJ, Altman DG. Statistics notes: Analysing controlled trials with baseline and follow up measurements. BMJ 2001;323:1123-1124.

102. Kernan WN, Viscoli CM, Makuch RW, Brass LM, Horwitz RI. Stratified randomization for clinical trials. J Clin Epidemiol 1999;52:19-26.

103. Covas MI, Nyyssonen K, Poulsen HE, et al. The effect of polyphenols in olive oil on heart disease risk factors: a randomized trial. Ann Intern Med 2006;145:333341.

104. McLaughlin T, Reaven G, Abbasi F, et al. Is there a simple way to identify insulinresistant individuals at increased risk of cardiovascular disease? Am J Cardiol 2005;96:399-404.

105. Lovejoy JC, Smith SR, Champagne CM, et al. Effects of diets enriched in saturated (palmitic), monounsaturated (oleic), or trans (elaidic) fatty acids on insulin sensitivity and substrate oxidation in healthy adults. Diabetes Care 2002;25:12831288.

106. Corpeleijn E, Feskens EJ, Jansen EH, et al. Improvements in glucose tolerance and insulin sensitivity after lifestyle intervention are related to changes in serum fatty acid profile and desaturase activities: the SLIM study. Diabetologia 2006;49:23922401.

107. Bos MB, de Vries JHM, Feskens EJM, et al. Effect of a high monounsaturated fatty acids diet and a Mediterranean diet on serum lipids and insulin sensitivity in adults with mild abdominal obesity. Submitted for publication.

108. Barter PJ, Ballantyne CM, Carmena R, et al. Apo B versus cholesterol in estimating cardiovascular risk and in guiding therapy: report of the thirty-person/tencountry panel. J Intern Med 2006;259:247-258.

109. Dobiasova M, Urbanova Z, Samanek M. Relations between particle size of HDL and LDL lipoproteins and cholesterol esterification rate. Physiol Res 2005;54:159165.

110. Alagona C, Soro A, Ylitalo K, Salonen R, Salonen JT, Taskinen MR. A low high density lipoprotein (HDL) level is associated with carotid artery intimamedia thickness in asymptomatic members of low HDL families. Atherosclerosis 2002;165:309-316.

111. de Roos B, Geelen A, Ross K, et al. Identification of potential serum biomarkers of inflammation and lipid modulation that are altered by fish oil supplementation in healthy volunteers. Proteomics 2008;8:1965-1974.

112. Moeller SM, Reedy J, Millen AE, et al. Dietary patterns: challenges and opportunities in dietary patterns research an Experimental Biology workshop, April 1, 2006. J Am Diet Assoc 2007;107:1233-1239.

113. Waijers PM, Feskens EJ, Ocke MC. A critical review of predefined diet quality scores. Br J Nutr 2007;97:219-231. 
114. Vincent-Baudry S, Defoort C, Gerber M, et al. The Medi-RIVAGE study: reduction of cardiovascular disease risk factors after a 3-mo intervention with a Mediterranean-type diet or a low-fat diet. Am J Clin Nutr 2005;82:964-971.

115. Buckland G, Bach A, Serra-Majem L. Obesity and the Mediterranean diet: a systematic review of observational and intervention studies. Obes Rev 2008;9:582593.

116. di Giuseppe R, Bonanni A, Olivieri M, et al. Adherence to Mediterranean diet and anthropometric and metabolic parameters in an observational study in the 'Alto Molise' region: the MOLI-SAL project. Nutr Metab Cardiovasc Dis 2008; 18:415-421.

117. Pitsavos C, Milias GA, Panagiotakos DB, Xenaki D, Panagopoulos G, Stefanadis C. Prevalence of self-reported hypertension and its relation to dietary habits, in adults; a nutrition \& health survey in Greece. BMC Public Health 2006;6:206.

118. Sanchez-Tainta A, Estruch R, Bullo M, et al. Adherence to a Mediterranean-type diet and reduced prevalence of clustered cardiovascular risk factors in a cohort of 3,204 high-risk patients. Eur J Cardiovasc Prev Rehabil 2008;15:589-593.

119. Nunez-Cordoba JM, Valencia-Serrano F, Toledo E, Alonso A, Martinez-Gonzalez MA. The Mediterranean diet and incidence of hypertension: the Seguimiento Universidad de Navarra (SUN) Study. Am J Epidemiol 2009;169:339-346. 


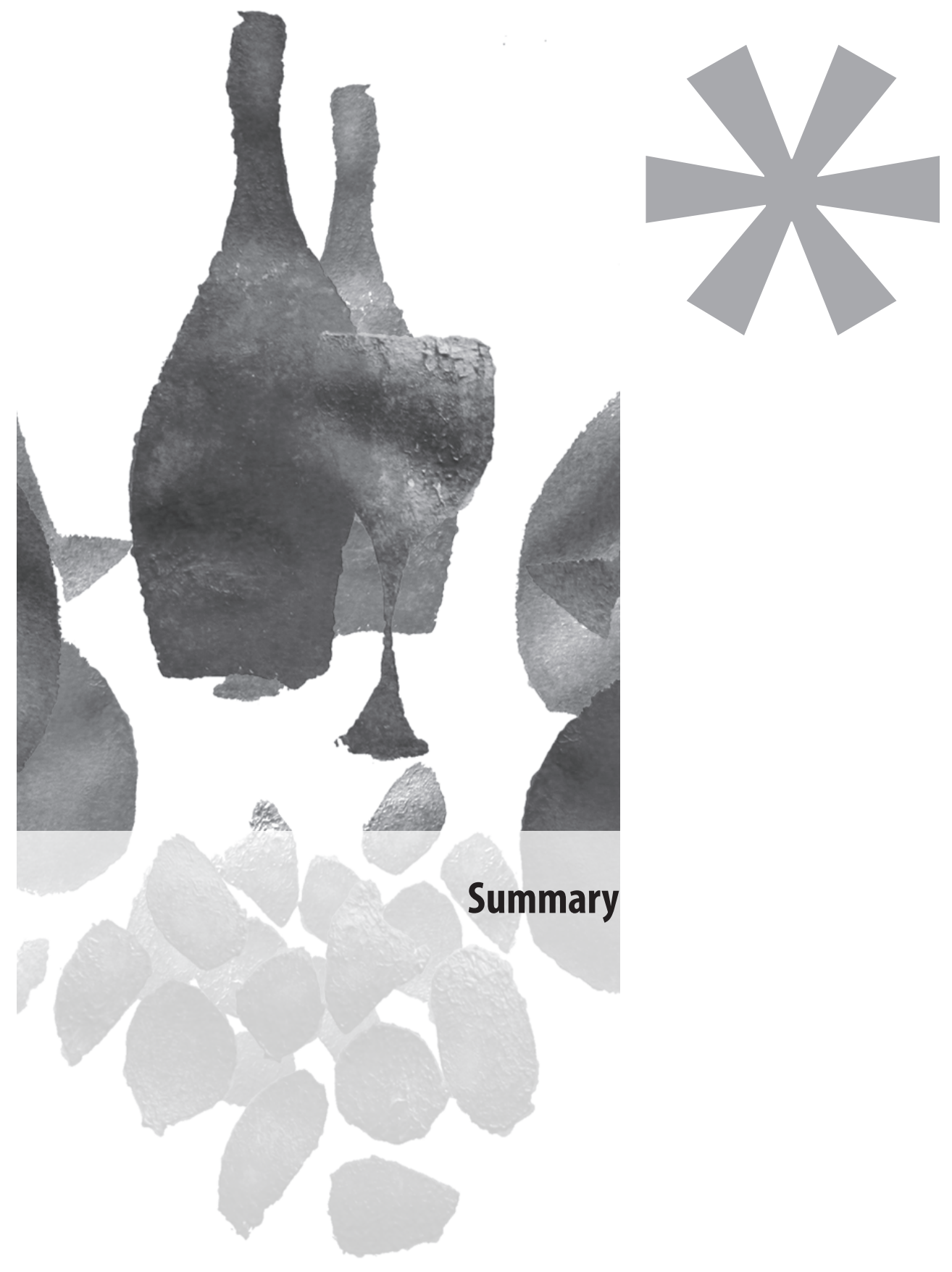




\section{The metabolic syndrome}

The metabolic syndrome refers to a clustering of risk factors including abdominal obesity, hyperglycaemia, low HDL-cholesterol, hypertriglyceridaemia, and hypertension and is a risk factor for diabetes mellitus type 2 and cardiovascular disease. According to the definition of the National Cholesterol Education Program 2001 (NCEP), the metabolic syndrome is present if at least three out of five characteristics are present: abdominal obesity (waist circumference $>102 \mathrm{~cm}$ for men and $>88 \mathrm{~cm}$ for women), hyperglycaemia (glucose concentration $\geq 6.1 \mathrm{mmol} / \mathrm{L}$ ), low HDL-cholesterol concentration (HDL-cholesterol concentration $<1.04 \mathrm{mmol} / \mathrm{L}$ for men and $<1.29$ $\mathrm{mmol} / \mathrm{L}$ for women), hypertriglyceridaemia (triglyceride concentration $\geq 1.7 \mathrm{mmol}$ ), and hypertension (systolic blood pressure $\geq 130 \mathrm{mmHg}$ or diastolic blood pressure $\geq 85$ $\mathrm{mmHg}$ ). According to our own observations, the prevalence of the metabolic syndrome in the Netherlands was 14\% in adults below 60 years of age in the 1990s (chapter 2 ). When this prevalence is extrapolated to the Dutch population, it corresponds to approximately 1 million persons with the metabolic syndrome in the 1990s.

\section{Mediterranean diet}

Underlying risk factors for the metabolic syndrome are physical inactivity and an unhealthy diet. Therefore, lifestyle changes may play an important role in the prevention of the metabolic syndrome. A Mediterranean diet has been considered a healthy diet as it has been associated with a reduced risk of mortality. A Mediterranean diet might also have favourable effects on the metabolic syndrome. A Mediterranean diet refers to a dietary pattern as consumed in countries of the Mediterranean region during the early 1960s. Characteristics of a Mediterranean diet are use of olive oil as the main added lipid, abundant use of plant foods (fruits, vegetables, cereals, legumes, nuts, and seeds), moderate intake of fish and wine, and low to moderate consumption of dairy products and meat and poultry. In this thesis, we studied whether a Mediterranean diet favourably affects the metabolic syndrome.

\section{Observational studies}

We studied whether a Mediterranean diet is associated with the metabolic syndrome in two observational studies. First we analysed this association in a European elderly population using baseline data of the Survey in Europe on Nutrition and the Elderly, a Concerted Action (SENECA) (chapter 3). The SENECA study was carried out in 1988-1989 and included 627 men and 631 women, aged between 70 and 76 years from 10 European countries. Adherence to a Mediterranean diet was assessed by the Mediterranean diet score that was developed by Trichopoulou et al. (MDS, range 0 through 9). Although not statistically significant, elderly subjects with good adherence to a Mediterranean diet (MDS $>4$ (median)) had a lower prevalence of the metabolic syndrome (prevalence ratio $0.81,95 \% \mathrm{CI} 0.65 ; 1.03$ ) and tended to have smaller waist circumference $(-1.1 \mathrm{~cm}, 95 \% \mathrm{CI}-2.4 ; 0.3)$ than elderly subjects with poor adherence. Good adherence to a Mediterranean diet was associated with higher HDL-cholesterol $(0.05 \mathrm{mmol} / \mathrm{L}, 95 \% \mathrm{CI} 0.00 ; 0.10)$ and lower triglyceride concentrations $(-0.12 \mathrm{mmol} / \mathrm{L}$, $95 \% \mathrm{CI}-0.24 ; 0.00)$ but not with measures of insulin sensitivity. These results implicate that the prevalence of the metabolic syndrome is lower in elderly people with good 
adherence to a Mediterranean diet.

Second, we analysed the association between a Mediterranean diet and the metabolic syndrome in the baseline data of the Cohort study on Diabetes and Atherosclerosis Maastricht (CoDAM) in the Netherlands. The CoDAM study was carried out in 19992000 and included 450 subjects ( 275 healthy subjects with normal glucose tolerance, 111 subjects with impaired glucose regulation and 64 subjects with diabetes mellitus type 2). Adherence to a Mediterranean diet was assessed by the Mediterranean diet score (MDS, range 0 through 9). In this study, a Mediterranean diet was not associated with the prevalence of the metabolic syndrome (prevalence ratio $1.0,95 \% \mathrm{CI} 0.8 ; 1.2$ ).

\section{Intervention study}

In addition, we conducted a controlled-feeding trial to compare the effects of replacing a high saturated fatty acids (SFA) diet with a high monounsaturated fatty acids (MUFA) diet or a Mediterranean diet on characteristics of the metabolic syndrome: HDL-cholesterol and triglyceride concentrations, and glucose metabolism (glucose concentration and insulin sensitivity) (chapters 5 and 6). We included 60 subjects (40-65 years) with mild abdominal obesity. Subjects were provided with $90 \%$ of their daily energy needs. After a two week run-in diet high in SFA (19\% of total energy intake (energy-\%)), subjects were allocated to a high MUFA-diet (20 energy-\%), a Mediterranean diet (MUFA 21 energy-\%), or the high SFA-diet, for eight weeks. Replacing a high SFA-diet with a high MUFA or a Mediterranean diet did not affect insulin sensitivity, but decreased total cholesterol, LDL-cholesterol and triglyceride concentrations. In addition, this trial showed that a Mediterranean diet increased HDL-cholesterol more than the diet high in MUFA did.

\section{General conclusion}

The results of our studies together with the results of other studies support the hypothesis that a Mediterranean diet has a beneficial effect on two characteristics of the metabolic syndrome: HDL-cholesterol and triglyceride concentrations, and probably also on a third characteristic of the metabolic syndrome: waist circumference.

As this thesis finds support for a favourable effect on two out of five characteristics of the metabolic syndrome and also suggests a favourable effect on a third characteristic, we conclude that a Mediterranean diet may help to prevent the metabolic syndrome, and consequently diabetes mellitus type 2 and cardiovascular disease. 


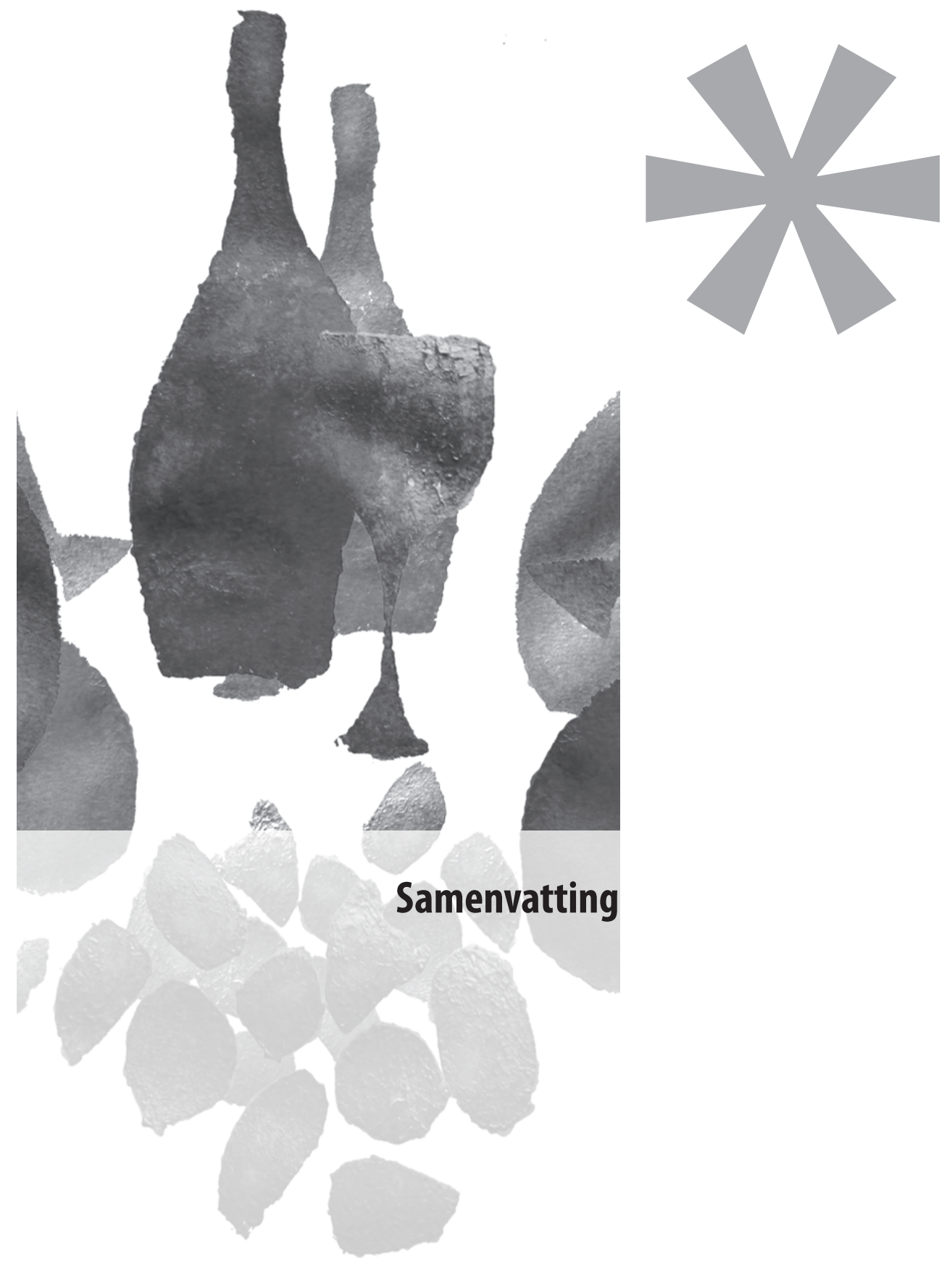


Samenvatting

\section{Metabool syndroom}

Het metabool syndroom is een belangrijke risicofactor voor diabetes mellitus type 2 en hart- en vaatziekten. Het metabool syndroom refereert aan een clustering van risicofactoren gerelateerd aan abdominale obesitas, hyperglycemie, dyslipidemie en hypertensie. Volgens de definitie van het National Cholesterol Education Program 2001 is het metabool syndroom aanwezig wanneer aan minimaal drie van de volgende criteria is voldaan: abdominale obesitas (middelomvang $>102 \mathrm{~cm}$ voor mannen en $>88 \mathrm{~cm}$ voor vrouwen), hyperglycemie (nuchtere glucoseconcentratie $\geq 6.1 \mathrm{mmol} / \mathrm{L}$ ), HDL-cholesterolconcentratie $<1.04 \mathrm{mmol} / \mathrm{L}$ voor mannen en $<1.29 \mathrm{mmol} / \mathrm{L}$ voor vrouwen, hypertriglyceridemie (triglyceridenconcentratie $\geq 1.7 \mathrm{mmol} / \mathrm{L}$ ), hypertensie (systolische bloeddruk $\geq 130 \mathrm{mmHg}$ en/of diastolische bloeddruk $\geq 85 \mathrm{mmHg}$ ). Uit ons onderzoek bleek dat de prevalentie van het metabool syndroom in Nederland in personen jonger dan 60 jaar 14\% was (hoofdstuk 2). Wanneer dit percentage wordt geëxtrapoleerd naar de Nederlandse bevolking komt dit overeen met circa 1 miljoen personen met het metabool syndroom in de jaren '90.

\section{Mediterrane voeding}

Onderliggende risicofactoren voor het metabool syndroom zijn onder meer weinig lichamelijke activiteit en een ongezonde voeding. Veranderingen in voedingsgewoonten kunnen een rol spelen bij de preventie van het metabool syndroom. Van een voeding volgens een Mediterraan patroon wordt bijvoorbeeld verwacht dat deze gunstige effecten zou kunnen hebben op het metabool syndroom. Een Mediterrane voeding wordt gekarakteriseerd door ruimschoots gebruik van olijfolie, hoge consumptie van groente, fruit, graanproducten, peulvruchten, noten en zaden, matige consumptie van vis en wijn en lage consumptie van zuivelproducten, vlees en gevogelte. In dit proefschrift hebben we onderzocht of een Mediterrane voeding een gunstig effect heeft op het metabool syndroom.

\section{Observationele studies}

In twee observationele studies hebben we de relatie tussen het eten volgens een Mediterraan patroon en het metabool syndroom onderzocht. De eerste studie waarin we dit zijn nagegaan is de SENECA studie (hoofdstuk 3). SENECA is een acroniem voor 'Survey in Europe on Nutrition and the Elderly, a Concerted Action' De SENECA studie is een studie onder ouderen tussen de 70 en 76 jaar uit 10 Europese landen. De data van de SENECA studie zijn verzameld in 1988 en 1989. De Mediterrane voedingsscore (MVS) die ontwikkeld is door Trichopoulou et al. is gebruikt om vast te stellen of er volgens een Mediterraan patroon werd gegeten. Uit deze studie bleek dat ouderen die volgens een Mediterraan patroon aten (MVS >4) minder hoge HDL-cholesterolconcentraties $(0.05 \mathrm{mmol} / \mathrm{L}, 95 \% \mathrm{CI} 0.00 ; 0.10)$ en lagere triglyceridenconcentraties $(-0.12 \mathrm{mmol} / \mathrm{L}, 95 \% \mathrm{CI}-0.24 ; 0.00)$ hadden dan ouderen die niet Mediterraan aten. Tevens leek het erop dat ouderen die Mediterraan aten minder vaak het metabool syndroom hadden (prevalentieratio $0.81,95 \% \mathrm{CI} 0.65$; $1.03)$ en een smallere middelomvang hadden $(-1.1 \mathrm{~cm}, 95 \% \mathrm{CI}-2.4 ; 0.3)$ dan ouderen die niet Mediterraan aten. De laatste twee bevindingen waren echter niet statistisch significant. 
De tweede studie waarin we de relatie tussen het eten volgens een Mediterraan patroon en het metabool syndroom hebben onderzocht is de CoDAM studie (hoofdstuk 4). CoDAM is een acroniem voor 'Cohort study on Diabetes and Atherosclerosis Maastricht'. Deze studie is uitgevoerd in Maastricht in 1999 en 2000 en omvatte 450 deelnemers. Van deze deelnemers hadden 64 diabetes mellitus type 2, 11 een verstoorde glucosetolerantie en 275 een normale glucose tolerantie. In deze studie bleek geen duidelijk verband te bestaan tussen de mate waarin de deelnemers een Mediterrane voeding gebruikten en de prevalentie van het metabool syndroom (prevalentieratio $1.0,95 \%$ CI $0.8 ; 1.2$ ).

\section{Voedingsproef}

Vervolgens hebben we onderzocht wat het effect is van het vervangen van een voeding met veel verzadigd vet (VV) door een voeding met veel enkelvoudig onverzadigd vet (EOV) of een Mediterrane voeding op enkele componenten van het metabool syndroom. Dit gebeurde in een 10 weken durende volledig gecontroleerde voedingsproef met 60 deelnemers tussen de 40 en 65 jaar (hoofdstukken 5 en 6). De deelnemers aan deze voedingsproef kregen $90 \%$ van hun voeding verstrekt. $\mathrm{Na}$ een inloopperiode van 2 weken werden ze verdeeld over drie groepen om vervolgens gedurende 8 weken een 'westerse' voeding rijk aan verzadigd vet (VV 19\% van de totale energie-inname (energie-\%)), een voeding rijk aan enkelvoudig onverzadigd vet (EOV 20 energie-\%), of een Mediterrane voeding (EOV 21 energie-\%) te gebruiken. De voeding rijk aan enkelvoudig onverzadigd vet en de Mediterrane voeding verhoogden de gevoeligheid voor insuline niet ten opzichte van de 'westerse' voeding. De voeding rijk aan enkelvoudig onverzadigd vet en de Mediterrane voeding verlaagden de cholesterol- en triglyceridenconcentraties. Verder zagen we dat de Mediterrane voeding de HDLcholesterolconcentratie verhoogde terwijl dit niet het geval was voor de voeding rijk aan enkelvoudig onverzadigd vet.

\section{Conclusie}

Onze onderzoeksresultaten samen met de onderzoeksresultaten van anderen, laten zien dat een Mediterrane voeding een gunstig effect heeft op twee van de vijf componenten van het metabool syndroom namelijk HDL-cholesterol- en triglyceridenconcentraties. Verder suggereren onze resultaten uit de SENECA studie dat een Mediterrane voeding ook een gunstig effect heeft op een derde component van het metabool syndroom, namelijk de middelomvang. We kunnen daarom concluderen dat een Mediterrane voeding kan helpen om het metabool syndroom te voorkomen en daarmee het risico op het krijgen van diabetes mellitus type 2 en hart- en vaatziekten te verlagen. 


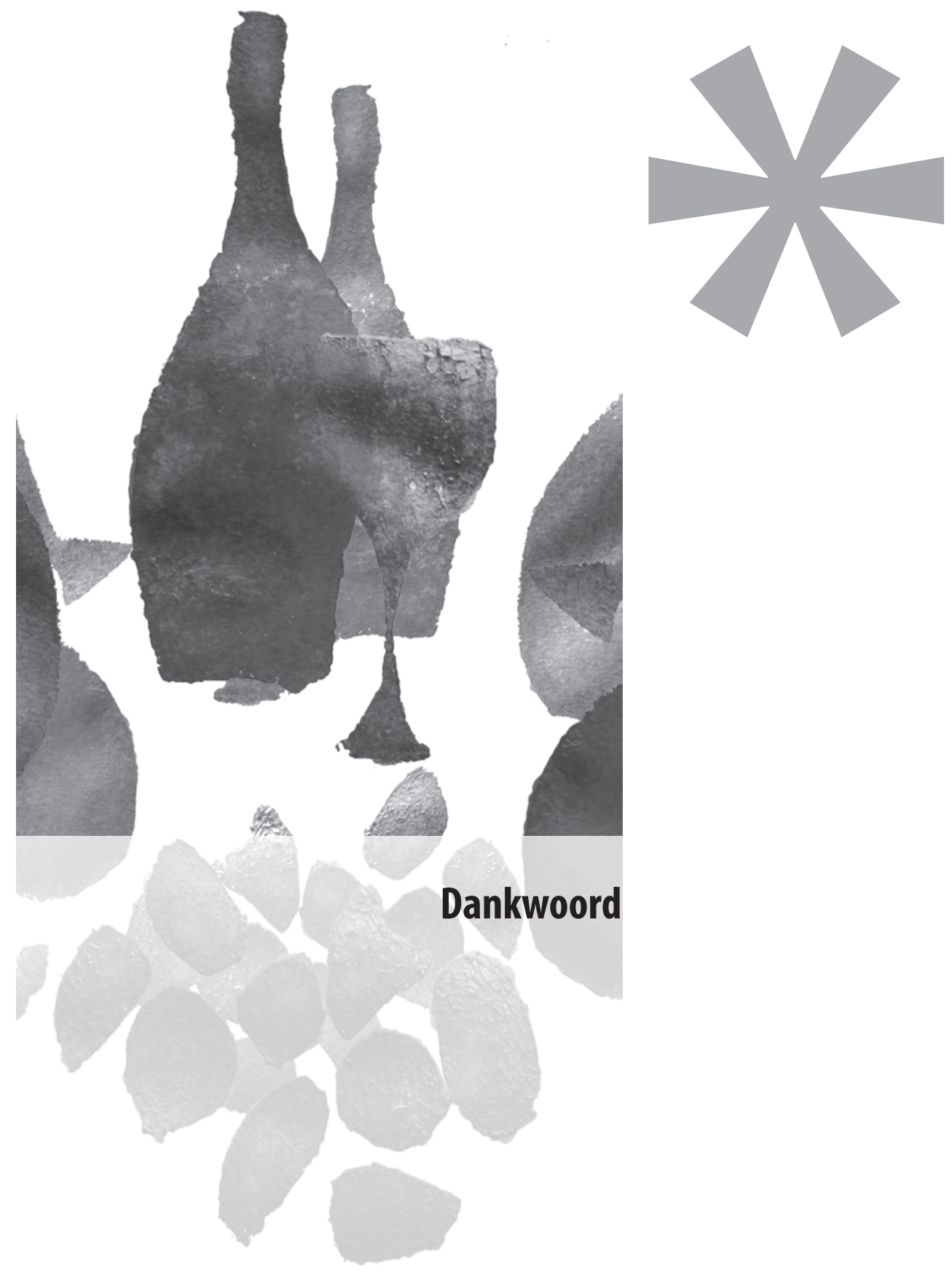


$\mathrm{Na}$ meer dan 4 jaar werken aan dit proefschrift zijn er veel mensen die ik graag wil bedanken voor hun hulp en betrokkenheid bij mijn promotieonderzoek.

Mijn eerste woorden van dank gaan uit naar mijn promotoren Lisette de Groot en Edith Feskens en co-promotor Jeanne de Vries. Hartelijk dank voor jullie begeleiding waardoor ik dit resultaat heb kunnen behalen. Ik waardeer het zeer dat jullie ondanks jullie volle agenda's toch altijd tijd voor mij vrijmaakten. Het waren 4 leerzame jaren voor mij en ik wil jullie bedanken voor het delen van jullie expertise, jullie betrokkenheid bij het project en voor alle mogelijkheden die jullie mij hebben gegeven.

Het eerste jaar van mijn promotieonderzoek heb ik doorgebracht op de afdeling 'Centrum voor Voeding en Gezondheid' (CVG) van het Rijksinstituut voor Volksgezondheid en Milieu (RIVM). Ik wil alle CVG-ers heel hartelijk bedanken voor de leuke tijd die ik bij jullie heb gehad. Martinette en Brian, fijn dat ik altijd met jullie mee kon rijden naar Bilthoven. Daphne, ik vond het erg leuk om met jou een kamer te delen, dank je wel voor alle gezelligheid. Verder wil ik Hans Verhagen bedanken voor zijn betrokkenheid bij mijn project en zijn waardevolle suggesties voor mijn manuscripten.

Beste deelnemers van de MARIS studie, het valt niet mee om 10 weken mee te doen aan een voedingsproef zoals de MARIS studie. Ik heb grote waardering voor jullie inzet, enthousiasme, trouw en toewijding en ik wil jullie bedanken voor de gezellige sfeer tijdens de studie. Karin en Els, dank jullie wel voor jullie harde werk tijdens de voorbereiding en de uitvoering van de MARIS studie. Mede door jullie enthousiasme en gedrevenheid is de MARIS studie een succes geworden. Dianne, Sietske, Suzanne, Nadine, Jolien, Bram-Sieben, Laura, Ellen, Pasha, Paulette, Evert, Jenneke, Verena, Myrthe, Helmi en het hele MARIS onderzoeksteam, jullie inzet tijdens de proef was geweldig! Marga en Jantien, bedankt voor jullie hulp bij de organisatie en uitvoering van al onze metingen. Diana, Isabelle, Mechteld, Jan en Sonja, hartelijk dank voor jullie hulp bij alle bloedafnames en de metingen in de Gelderse Vallei. Susan, dank je wel voor de organisatie van de insuline clamps en voor de goede samenwerking. Ik wens je veel succes met jouw promotieonderzoek. Rik Heijligenberg en Dianne Hoelen wil ik heel hartelijk bedanken voor het mogelijk maken en het uitvoeren van de metingen in de Gelderse Vallei. Annet Roodenburg en Peter Zock, hartelijk dank voor de wetenschappelijke en financiële ondersteuning van de MARIS studie.

Elvira, Ellen, Verena, Myrthe en Sandra, ik vond het erg leuk om jullie te mogen begeleiden tijdens jullie afstudeervak en ik heb veel van jullie geleerd. Ik wens jullie veel succes toe in de toekomst.

Alle collega's en oud-collega's van de vakgroep Humane Voeding wil ik graag bedanken voor de goede sfeer en de leuke tijd die ik bij jullie heb gehad. Janette en Linda, mijn buurvrouwen, wil ik graag bedanken voor het meeleven met alle ups en downs van het aio-bestaan. Fijn dat ik altijd langs kon komen voor een praatje. Ook veel dank aan de andere 'buren' van de eerste verdieping van het Agrotechnion, Anne, Janneke, Wieke, Michael, Bianca en Truus voor alle belangstelling en steun maar vooral voor de leuke tijd die ik met jullie heb gehad. Janny, bedankt voor de gezelligheid en de 'grappige' cadeautjes (en pas op voor bellenblaas en sneeuwballen!). Gertrude, dank je wel voor de leuke en sportieve fitnessuurtjes. Anand, thank you for dropping by so many times and for all Friday-afternoon drinks. Drupadi, terimah kasih banyak, for 
the wonderful time we had together and for all delicious Indonesian dinners. Pascalle, Renate, Martinette, Gerda, David en Mark, ik vond het erg leuk om samen met jullie de PhD-tour te organiseren. Karen, Gabriëlle, Gea en Marie, bedankt voor het maken van alle afspraken en de secretariële ondersteuning.

Renate Siebes, dank je wel voor het lay-outen van mijn proefschrift en Kitty van der Veer, bedankt voor het ontwerpen van de omslag. Ik ben de Nederlandse Hartstichting erkentelijk voor het financieel mogelijk maken van mijn promotieonderzoek.

Naast alle mensen die direct te maken hebben gehad met mijn project, wil ik ook graag mijn vrienden en familie bedanken voor hun belangstelling voor mijn promotieonderzoek en alle zaken eromheen.

Alex en Nelleke, dank jullie wel voor jullie belangstelling en vriendschap. Ik vind het fijn dat we straks weer wat dichter bij jullie gaan wonen en dat we elkaar weer wat vaker kunnen zien. Christian, het was gezellig om samen te lunchen in het Biotechnion en de Griekse en Peruaanse etentjes samen met Christina en Alejandro zijn altijd erg leuk. Jan-Willem, Ellen, Richard en Germa, onze kampeervakanties op Terschelling waren erg geslaagd zeker door alle spannende excursies op het wad onder leiding van Jan-Willem. Annemarieke, Jolande en Bart, onze reisjes naar Taizé vond ik mooi en inspirerend. Annemarieke, ik moet nog altijd denken aan de lol die we hebben gehad bij het "tapen" van de boekjes en de botsing die we al dweilende maakten midden op het podium. Bart en Judith, heerlijk om met jullie te ouwehoeren en te lachen in de kroeg. Zullen we snel weer iets afspreken? Judith, ik vind het erg leuk dat je weer in Nederland woont. Dank je wel voor al je support en het doorlezen van mijn teksten. Susann, we kunnen urenlang samen kletsen wat ik altijd erg gezellig vind. Lilian, onze belevenissen in Jakarta hebben ons een hele leuke vriendschap opgeleverd. Ik wil je heel veel succes wensen met jouw promotie en natuurlijk heel veel geluk voor jou en Samadh op jullie speciale dag. Saskia en Arjen, bedankt voor de gezellige etentjes. Binnenkort bij ons? Pieter, dank je wel voor de steun die je me hebt gegeven tijdens de eerste jaren van mijn aio-tijd. Aukje, we kennen elkaar al jaren en hoewel het soms lastig is om elkaar vaak te zien, stel ik onze vriendschap nog steeds heel erg op prijs.

I would like to thank Arnold, Brenda, Danielle, Alexandre, Jolande, Claudia, Caucasella, Luis, Katarina, Ingeborg, Josine, Yansen, Anja, Anne, Katia, Evi, Joebel, Jed and all other friends from "in de wereld-SP3" and the "Wageningen Student Chaplaincy" for the discussion evenings, Taizé meetings, movies, dinners, Sunday services and many other inspiring activities.

Dhr. "opa" de Korver wil ik hartelijk bedanken voor zijn interesse in mijn promotieonderzoek en ik vind het erg fijn dat u er bij wilt zijn op mijn promotie. Jaap en Connie, muchas gracias voor jullie gastvrijheid en de gezellige avondjes.

Karianne, al jaren bespreken we regelmatig de grote en kleine dingen van het leven. We hebben inmiddels al heel wat uurtjes doorgebracht in de cafeetjes op de markt. Ik waardeer je scherpe blik, je gezelligheid en je vriendschap enorm en ik ben erg blij dat jij mijn paranimf wilt zijn. Dank je wel voor alles.

Carla, sinds onze studententijd delen we al een werkkamer, maar we zijn nog steeds niet uitgekletst en uitgelachen. Allereerst bedankt voor je vriendschap maar zeker ook 
voor je steun, medeleven, meedenken, gezelligheid, creativiteit, humor en enthousiasme. Zonder jou was mijn aio-tijd een stuk minder leuk geweest ("Ohne dich ist alles doof!"). Ik ben ontzettend blij dat we het nu allebei hebben gehaald en ik vind het superfijn dat je straks naast me staat op het podium.

Mi familia en Perú, Consuelo, Rosa María, Rocío, Carmen, Christian, Eduardo, María Christina, Gilmer, Marianella, Christel, Isabel, Tomás, Denisse y Kevin, muchas gracias por las bonitas vacaciones que he pasado con ustedes. Me alegra haberlos conocido y esperamos poder venir pronto otra vez.

Lieve pap en mam, dank jullie wel voor de steun die jullie mij hebben gegeven en het vertrouwen dat jullie altijd in mij hebben gehad. Jose en Gerjan, ik vind het altijd gezellig om bij jullie te zijn en het is erg mooi om jullie meiden te zien opgroeien. Kirsten, Marit en Lotta, jullie zijn de liefste nichtjes van de wereld! Evelien, dank je wel voor je support en alle gezellige bezoekjes!

Lieve Alejandro, samen met jou ben ik heel gelukkig. Dank je wel voor je al je hulp, geduld, vertrouwen, en liefde. Muchas gracias por todos.

Marieke 


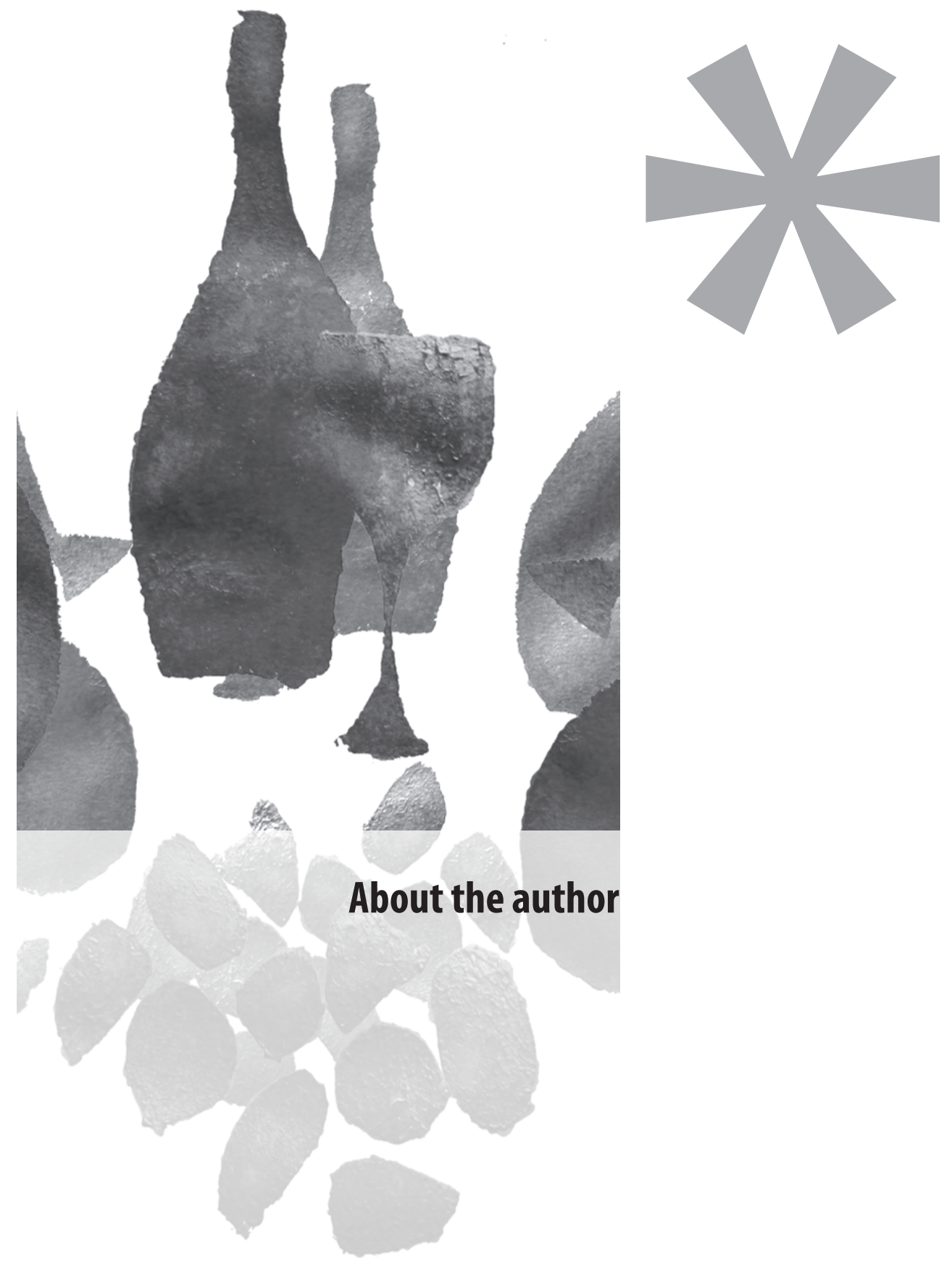




\section{Curriculum vitae}

Marieke Bos was born on the 15th of January 1979 in Hoogeveen, the Netherlands. In 1999, after graduating from secondary school at the Maartenscollege in Haren, she started her study 'Nutrition and Health' at Wageningen University and specialized in human nutrition and epidemiology. During her first MSc thesis she investigated the effect of supplementation of vitamin A and riboflavin on haemoglobin and ferritin concentrations of Indonesian adolescent schoolgirls also receiving iron supplements. She performed this research at Seameo Tropmed, University of Indonesia, Jakarta, Indonesia. She performed her second MSc thesis at the Netherlands Cancer Institute, Amsterdam, where she studied the effects of estradiol and physical activity on insulinlike growth factor system. She fulfilled her practical training at the University Medical Centre in Groningen where she studied the effects of smoking on albuminuria. After her graduation in 2004, she started her PhD project about the effect of a Mediterranean diet on the metabolic syndrome at the division of Human Nutrition, Wageningen University. This $\mathrm{PhD}$ project was funded by the Netherlands Heart Foundation and was carried out in cooperation with the National Institute for Public Health and the Environment (RIVM). She is currently working at the Netherlands Heart Foundation in Den Haag. 


\section{List of publications}

Bos MB, de Vries JHM, Feskens EJM, van Dijk SJ, Hoelen DWM, Siebelink E, Heijligenberg R, de Groot CPGM. Effect of a high monounsaturated fatty acids diet and a Mediterranean diet on serum lipids and insulin sensitivity in adults with mild abdominal obesity. Submitted for publication.

Van Dijk SJ, Feskens EJM, Bos MB, Hoelen DWM, Heijligenberg R, Grootte-Bromhaar M, de Groot CPGM, de Vries JHM, Müller M, Afman LA. A saturated fatty acid rich diet can induce an 'obese gene expression profile' in adipose tissue of subjects at risk for metabolic syndrome. Submitted for publication.

$\underline{\text { Bos MB}}$, Feskens EJM, de Vries JHM, Geurts ME, de Groot CPGM. Association between a Mediterranean diet and the metabolic syndrome in elderly European subjects: the SENECA study. Submitted for publication.

$\underline{\text { Bos MB}}$, de Groot CPGM, de Vries JHM, Blaak EE, Verhagen H, van Greevenbroek, MMJ, van der Kallen, CJH, Ferreira I, Stehouwer, CDA, Feskens EJM. Association between a Mediterranean diet and markers of glucose metabolism in Dutch adults: the CoDAM study. Submitted for publication.

Bos MB, de Vries JHM, Wolffenbuttel BHR, Verhagen H, Hillege JL, Feskens EJM. De prevalentie van het metabool syndroom in Nederland: verhoogd risico op hart- en vaatziekten en diabetes mellitus type 2 bij een kwart van de personen jonger dan 60 jaar. Nederlands Tijdschrift voor Geneeskunde 2007;151:2382-2388.

van der Klaauw AA, Biermasz NR, Feskens EJM, Bos MB, Smit JW, Roelfsema F, Corssmit EP, Pijl H, Romijn JA, Pereira AM. The prevalence of the metabolic syndrome is increased in patients with GH deficiency, irrespective of long-term substitution with recombinant human GH. European Journal of Endocrinology 2007;156:455-462.

$\underline{\text { Bos MB}}$, de Vries JHM. Mediterranean-inspired diet. Insuline Resistentie 2006;5(4);14.

\section{Published abstracts}

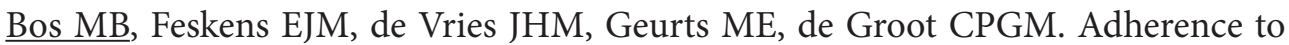
a Mediterranean type of diet and components of the metabolic syndrome in elderly European subjects. Circulation 2009;199:e301.

Van Dijk SJ, Feskens EJM, Bos MB, Hoelen DWM, Heijligenberg R, Grootte-Bromhaar M, de Vries JHM, Müller M, Afman LA. A saturated fatty acid rich diet can induce an 'obese gene expression profile' in adipose tissue of subjects at risk for metabolic syndrome. Journal of Diabetes 2009;1:S1-A275.

$\underline{B}$ os MB, de Vries JHM, Feskens EJM, van Dijk SJ, Hoelen DWM, Siebelink E, Heijligenberg R, de Groot CPGM. Effect of a high MUFA-diet and a Mediterranean type of diet on serum lipids and insulin sensitivity in adults with mild abdominal obesity. Journal of Diabetes 2009;1:S1-A278.

van Dijk SJ, Afman LA, Bos MB, Hoelen D, Grootte-Bromhaar M, de Vries JHM, Heijligenberg R, Müller M, Feskens E.J.M. Mediterranean diet and the prevention of type 2 diabetes; impact of monounsaturated fatty acids on insulin sensitivity and underlying mechanisms. Chemistry and physics of lipids 2008;154:S45. 


\section{Overview of training activities}

\section{General courses}

PhD Introduction week, 2004

VLAG graduate school, Bilthoven, the Netherlands.

Scientific writing, 2005

Centa language centre, Wageningen, the Netherlands.

Media training, 2005 NWO, Den Haag, the Netherlands.

Techniques for writing and presenting a scientific paper, 2008

Wageningen Graduate Schools, Wageningen, the Netherlands.

Career perspectives, 2008

Wageningen Graduate Schools, Wageningen, the Netherlands.

\section{Specific courses}

Nutritional and Lifestyle epidemiology, 2005

VLAG graduate school, Wageningen, the Netherlands.

Erasmus summer programme, 2005

'Regression analysis' and 'history of epidemiological ideas'

NIHES, Rotterdam, the Netherlands.

Master class Nutrigenomics 'From molecular nutrition to prevention of disease', 2005 VLAG graduate school, Wageningen, the Netherlands.

Master class 'Dietary Influences on Blood Pressure', 2006

VLAG graduate school, Wageningen, the Netherlands.

\section{Scientific meetings}

- Literature group 'Journal club', 2004-2006, Wageningen University, the Netherlands.

- Literature group 'Oldsmobiles', 2004-2008, Wageningen University, the Netherlands.

- WCFS Food summit 'Diet and the metabolic syndrome', 2004, Wageningen, the Netherlands.

- NWO Nutrition, 2004, 2005, Arnhem, 2008, Deurne, the Netherlands.

- EGEAIII International conference on health benefits of Mediterranean style diet, 2005, Rome, Italy.

- WEON, 2005, Wageningen, the Netherlands.

- PhD study tour to the United Kingdom and Ireland (member of organising committee), 2005.

- VI international congress on the Mediterranean diet, 2006, Barcelona, Spain.

- Symposium N-3 fatty acids and mental health 2007, VLAG graduate school, Wageningen, the Netherlands.

- PhD study tour to the USA, 2007.

- 5th World congress on prevention of diabetes and its complications 2008, Helsinki, Finland.

- 7e Wetenschapsdag, 2008, Nederlandse Hartstichting, Amsterdam, the Netherlands.

- Nutritional Sciences Forum, 2009, Wageningen University, Arnhem, the Netherlands.

- Nutrition, physical activity and metabolism conference, 2009, Palm Harbor, Florida, USA.

- 49th Cardiovascular disease epidemiology and prevention conference, 2009, Palm Harbor, Florida, USA.

- 3rd International congress on prediabetes and the metabolic syndrome, 2009, Nice, France. 
Financial support by the Netherlands Heart Foundation for the publication of this thesis is gratefully acknowledged. The research described in this thesis was supported by a grant of the Netherlands Heart Foundation (NHF-2003B068).

Cover design Kitty van der Veer Layout Renate Siebes, Proefschrift.nu

Printed by GVO drukkers \& vormgevers B.V.|Ponsen \& Looijen, Ede

(c) 2009 Marieke Bos 